\title{
Geology and Mineral Deposits of the Turtle Lake Quadrangle,
}

Washington

G E O L O G I A A S URVEY B UL L E T I N $1 \begin{array}{lllll}1 & 3 & 1\end{array}$

Prepared on behalf of the United States

Atomic Energy Commission

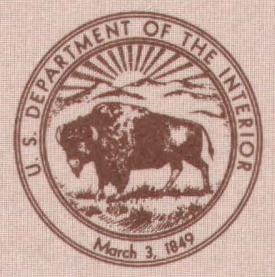





\section{Geology and Mineral Deposits of the Turtle Lake Quadrangle,}

\section{Washington}

By GEORGE E. BECRAFT and PAUL L. WEIS

G E O L O G I C A L S U R V E Y B U L L E T I N 11131

Prepared on behalf of the United States

Atomic Energy Commission 
UNITED STATES DEPARTMENT OF THE INTERIOR

GECIL D. ANDRUS, Secretary

GEOLOGICAL SURVEY

V. E. McKelvey, Director

First printing 1963
Second printing 1978

For sale by the Branch of Distribution, U.S. Geological Survey, 1200 South Eads Street, Arlington, VA 22202 


\section{CONTENTS}

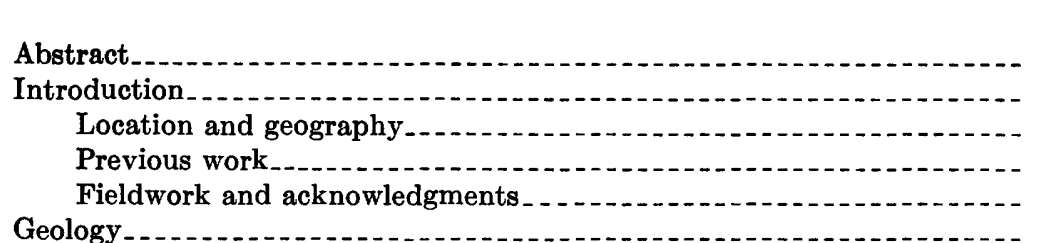

General features.... 5

Precambrian rocks.... 6

Deer Trail group

Togo formation.

Edna dolomite.

McHale slate. . .

Stensgar dolomite

Greenstone

Cambrian rocks.

Addy quartzite.......... 12

Old Dominion limestone of Weaver, 1920

Cambrian-Precambrian unconformity

Correlation of the Precambrian and Cambrian rocks

Paleozoic(?) rocks_.

Quartzite...... 19

Hornfels..........

Marble and phyllite

Age

Cretaceous rocks_... 25

Loon Lake granite..... 25

Granodiorite

Porphyritic quartz monzonite

Equigranular quartz monzonite

Fine-grained equigranular quartz monzonite

Fine-grained quartz monzonite rich in mafic minerals $\ldots . . .-29$

Alaskite, aplite, and pegmatite. 30

Granite porphyry

Lamprophyre

Rhyolite

Age

Tertiary rocks... 33

Gerome andesite 33

Flow rocks.... 33

Pyroclastic and sedimentary rocks.

Intrusive rocks.

Age 
Geology-Continued

Tertiary rocks-Continued Page

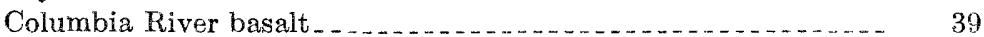

Distribution and general character

Petrography . .

Age

Quaternary deposits . .

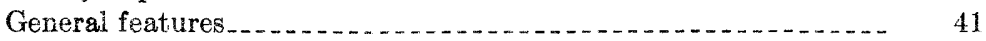

Palouse formation . . .

Glacial deposits undivided..... 47

Glacial moraine

Glacial lake silt . .

Quaternary alluvium

Landslides_...

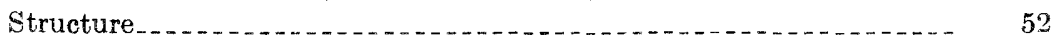

Folds . . . . .

Faults_...

Joints . . .

Cleavage . .

Spokane River Valley-Enterprise Valley lineament

Geologic history

Mineral deposits

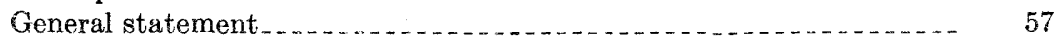

Uranium

General features

Midnite mine ..................... 58

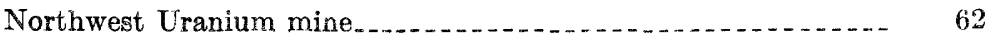

Lowley Lease.

Big Smoke mine

Deer Mountain prospect................ 67

Copper: O-Lo-Lim mine

Molybdenum: Spokane Molybdenum mine

Lead-zinc

Orazada mine

Valley View mine.... 69

Fouress (4-S) mine

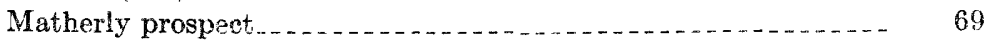

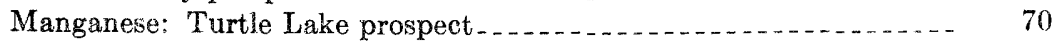

Tungsten: Germania Consolidated mine $\ldots 7 . \ldots 7 . \ldots$

Silica deposit.

Barite prospect............ 71

Coal prospect 71

Literature cited. 


\section{ILLUSTRATIONS}

[Plates are in pocket]

Plate 1. Geologic map and sections of the Turtle Lake quadrangle.

2. Correlation chart showing stratigraphic sections of the magnesite belt in southern Stevens County.

3. Geologic map of the Midnite mine.

4. Geologic map and sections of the Northwest Uranium mine.

5. Geologic map of the Lowley Lease.

6. Geologic map of the underground workings, Germania Consolidated mine.

Figury 1. Index map showing the location of the Turtle Lake quadrangle

Page

2. Generalized geologic map of the southern part of the magnesite belt

3. Generalized correlation diagram showing possible stratigraphic relations of Lower Cambrian and Precambrian rocks in northeastern Washington and southeastern British Columbia.

4. Flows of Gerome andesite . . . . . . . . . . . . . . . . .

5. Metasequoia occidentalis (Newberry) Chaney ...............

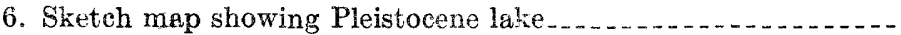

7. Glaciated outcrops of granodiorite northeast of Cayuse Mountain

8. Faulted tuffaceous and carbonaceous beds of Gerome andesite

9. Geologic map of the underground workings, Spokane molybdenum mine

10. Geologic map of the underground workings, Matherly prospect.

\section{TABLES}

TABLE 1. Chemical anakyses and calculated norms of rocks of the Loon

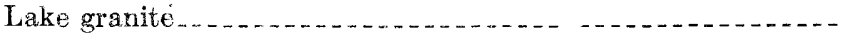

2. Lead-alpha age determinations of zircon from the Loon Lake

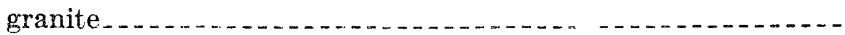

3. Chemical analyses and calculated norms of the Gerome andesite-

4. Chemical analyses and calculated norms of the Columbia River

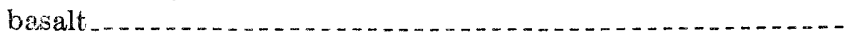

5. Equivalent uranium and uranium analyses of samples of carbonized wood from the Northwest Uranium mine . . . . . .

6. Semiquantitative spectrographic analyses of carbonized wood ash from the Northwest Uranium mine. 



\title{
GEOLOGY AND MINERAL DEPOSITS OF THE TURTLE LAKE QUADRANGLE, WASHINGTON
}

\author{
By George E. Becraft and Paul L. Weis
}

\begin{abstract}
The Turtle Lake quadrangle is in northern Lincoln and southern Stevens Counties, Wash., about 35 miles northwest of Spokane. The quadrangle is divided in half by the Spokane River, which also forms the boundary between parts of two strikingly different physiographic and geologic provinces-the Okanogan Highlands on the north and the Columbia plateau to the south. All of the quadrangle north of the Spokane River is in the Spokane Indian Reservation.

Rocks in the area range in age from Precambrian to Recent. The oldest rocks are the Precambrian phyllite, quartzite, and dolomite exposed in the northern and northwestern parts of the quadrangle. Small dikes and sills of greenstone that cut these metasedimentary rocks are probably also Precambrian in age. Lower Cambrian metasedimentary rocks unconformably overlie the Precambrian rocks in the northwestern part of the area. Quartzite, calc-silicate hornfels, calc-silicate marble, and phyllite of Paleozoic(?) age underlie part of the southeastern quarter of the quadrangle.

The Precambrian, Lower Cambrian, and Paleozoic(?) rocks have been intruded by a large mass of Cretaceous Loon Lake granite. The intrusive is predominantly quartz monzonite and granodiorite, but it also contains small bodies of pegmatite, alaskite, aplite, granite porphyry, rhyolite, and lamprophyre.

Flows, pyroclastic rocks, and intrusive rocks, which make up the Gerome andesite of Oligocene age, are distributed in a northwest-trending zone 2 to 4 miles wide along the Spokane River valley-Enterprise Valley lineament. Miocene Columbia River basalt forms most of the relatively flat plateau south of the Spokane River and also isolated patches north of the river. Loess, part of the Pleistocene Palouse formation, covers large areas south of the Spokane River. Glacial deposits of Pleistocene age, principally glaciofluvial and glaciolacustrine deposits, are extensive along the Spokane River valley and are locally present elsewhere in the quadrangle.

The metasedimentary rocks in the northern and northwestern part of the map area are part of the locally overturned west limb of the asymmetric, northeasttrending Deer Trail anticline. Paleozoic(?) metasedimentary rocks in the south eastern part of the quadrangle appear to be part of the southwestern limb of a southeastward- or eastward-plunging syncline.

The Precambrian rocks in the northern part of the area are commonly sheared, but no large amount of displacement can be recognized. Paleozoic(?) rocks in the southeastern quarter of the quadrangle are cut by three faults that appear to have displacements on the order of several hundred feet. A prominent lineament
\end{abstract}


extends from southeast to northwest across the quadrangle, along part of the Spokane River Valley and then northwest along Enterprise Valley, The fact that volcanic rocks of the Gerome are confined to the lineament suggests that it has existed at least since early Cenozoic time. The feature may be a fault or a fault zone; Precambrian and Lower Cambrian rocks on the southwestern side are at least $1 \frac{1}{2}$ miles west of where they would be expeeted from their projected strike on the northeastern side of the valley.

The mineral deposit of greatest economic value in the quadrangle is a large uranium deposit at the Midnite mine on the Spokane Indian Reservation in the n:rthcentral part of the area. The deposit consists of several ore bodies, some of which are several hundred feet long and more than one hundred feet wide, along an intrusive contact between Precambrian phyllite and Cretaceous porphyritic quartz monzonite. Except for small amounts of secondary minerals, the ore is almost entirely in the Precambrian rocks. The Midnite deposit, discovered in 1954, has been actively mined since early 1955 .

Another uranium deposit, the Northwest Uranium deposit, is in tuffaceous and sedimentary rocks of Gerome andesite, in the center of the quadrangle. Uranium is also present at the Lowley Lease and Big Smoke properties, near the Spokane River.

Tungsten has been mined intermittently at the Germania Consolidated mine, in the north-central part of the quadrangle, since about 1917. Total production is valued at about $\$ 134,000$.

Small prospects that contain lead, zinc, silver, and molybdenum have been explored in the area, but none have produced much ore.

\section{INTRODUCTION}

\section{LOCATION AND GEOGRAPHY}

The Turtle Lake quadrangle is in Stevens and Lincoln Counties in northeastern Washington. It is bounded by latitudes $47^{\circ} 45^{\prime}$ and $48^{\circ} 00^{\prime} \mathrm{N}$. and longitudes $118^{\circ} 00^{\prime}$ and $118^{\circ} 15^{\prime} \mathrm{W}$.; the eastern boundary is about 25 miles west of Spokane (fig. 1). The Spokane River arm of Franklin D. Roosevelt Lake extends across the quadrangle in a general northwestward direction and joins the Columbia River 4 miles west of the quadrangle. The lake (Spokane River) divides the quadrangle approximately in half, and forms the boundary line between Lincoln and Stevens counties. North of the lake, the land is entirely within the Spokane Indian Reservation (fig. 1). The main road across the reservation crosses the northern part of the quadrangle and State Highway 22 crosses the southwestern corner. The many graded roads on the reservation and the county roads south of the river make most of the area readily accessible. Most of the area drains into the Spokane River, but the southwestern corner is drained by Indian Creek and Snook Creek, tributaries of Hawk Creek which flows directly into the Columbia River.

The climate of the region is semiarid, and the precipitation is mostly in the form of snow in the winter months and as rain in the spring and fall. In the summer, precipitation generally comes as 


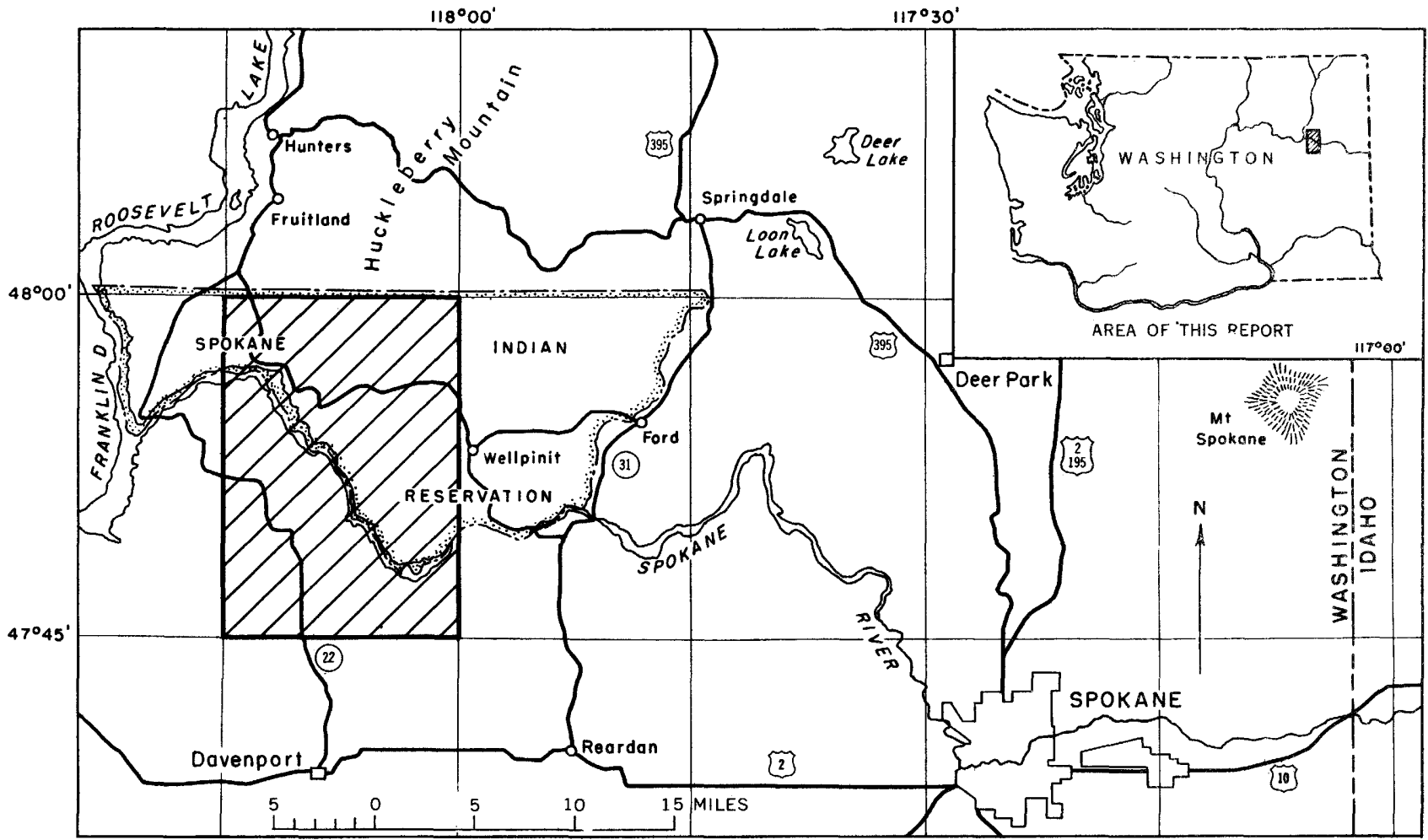

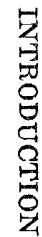

FIGURE 1.-Index map showing the location of the Turtle Lake quadrangle, Washington. 
thunderstorms. All the major streams in the quadrangle have a continuous flow throughout the year. The level of Franklin D. Roosevelt Lake which was created by the construction of Grand Coulee Dam on the Columbia River, fluctuates throughout the year depending upon the water level that is maintained at the dam.

Parts of two strikingly different physiographic provinces are present in the Turtle Lake quadrangle. Most of the area south of the Spokane River is part of the relatively flat Columbia plateau which ranges from about 2,500 feet to 2,600 feet above sea level on the quadrangle. The plateau is cut by many narrow steep-walled valleys, some of which are 800 feet deep. The interstream divides are generally wide and nearly flat. The area north of the Spokane River is part of the Okanogan Highlands. It has a mature topography, very slightly modified by glacial deposits, and the maximum relief is about 2,900 feet. The elevations range from 1,289 feet above sea level at the lake to 4,208 feet above sea level at the north edge of the map. The average local relief is about 500 to 700 feet.

\section{PREVIOUS WORK}

Much of the earlier geologic work in Stevens County was restricted to studies of individual mines and prospects north of the Turtle Lake quadrangle, but three excellent reports on the geology in and north of the quadrangle aided greatly in the present work. A report by C. E. Weaver (1920) contains a geologic map that includes part of the Turtle Lake quadrangle and information on the mines in Stevens County. Weaver described the first stratigraphic section for this area, and several formational names first proposed by him are used in this report. Two reports by W. A. G. Bennett $(1941,1944)$ on the magnesite belt in Stevens County expand and somewhat revise Weaver's interpretation of the structure and stratigraphy of the area north of the Turtle Lake quadrangle. Bennett's paper (1941) is the first published report in which the Precambrian rocks that extend into the northern part of the Turtle Lake quadrangle are subdivided. Bennett did not name these subdivisions, but Campbell and Loofbourow (1957) in a somewhat more detailed study of the area named the formations, and these names have been retained in the present study.

Two papers by Flint (1936 and 1937) on glaciation in northeastern Washington aided in the study of the glaciation in the Turtle Lake quadrangle.

Brief discussions of mines in the area are included in reports by Bancroft (1914), Bethune (1891), Landes and others (1902), Culver and Broughton (1945), Floyd and Stickney (1954), Patty (1921), Valentine (1949), and Huntting (1956). For other papers on the 
general area that are not listed under "Literature cited," the reader is referred to the complete bibliographies included in the reports by Weaver (1920), Bennett (1941), Huntting (1956), Valentine (1949), and Bretz and others (1956).

\section{FIELDWORK AND ACKNOWLEDGMENTS}

The Turtle Lake quadrangle was mapped during the summers of 1955,1956 , and 1957 as part of the study of the uranium deposits on the Spokane Indian Reservation. In 1955 Eugene L. Boudette and Paul L. Weis, assisted by Anthony B. Gibbons, mapped a small area in the vicinity of the Midnite mine. The mapping of the quadrangle was completed in 1956 and 1957 by Becraft and Weis, assisted in 1957 by William K. Benda and Meade B. Norman II. An index to the areas mapped is included in plate 1 . The mapping was done on behalf of the Division of Raw Materials of the U.S. Atomic Energy Commission. The geology was mapped at a scale of $1: 24,000$ on a topographic base for publication at the present scale. The geology of three uranium deposits was plotted on planetable topographic maps.

The authors are indebted to Robert G. Coleman, U.S. Geological Survey, for his helpful suggestions on two visits to the Midnite mine and for mineral identifications and other work on samples collected from the mine; to W. A. G. Bennett, Washington State Department of Conservation and Development, Division of Mines and Geology, for many helpful discussions on the geology of the region; and to many individuals and companies who freely gave information on mining properties within the quadrangle. The authors also thank the members of the Spokane Indian Tribe who helped in many ways.

\section{GEOLOGY \\ GENERAL FEATURES}

The oldest rocks in the Turtle Lake quadrangle are the Precambrian phyllite, quartzite, and carbonate rock exposed in the northern part of the map area (pl. 1). Many small greenstone dikes cut these rocks and are probably also Precambrian in age. Lower Cambrian rocks unconformably overlie the Precambrian rocks in the northwestern quarter of the quadrangle. Quartzite, calc-silicate hornfels, phyllite, and calc-silicate marble exposed in the southeastern corner of the map are believed to be of Paleozoic (?) age. A large intrusive body of Cretaceous age, consisting mainly of quartz monzonite and granodiorite but including small dikes of granite porphyry, alaskite and pegmatite, lamprophyre, and rhyolite, cuts the Precambrian and Paleozoic rocks. Lava flows and pyroclastic and associated sedimentary rocks of Oligocene age extend in a southeasterly direction across the quadrangle and rest on an erosional surface of considerable 
relief. Many dikes and sills associated with these volcanic rocks cut the older intrusive and metasedimentary rocks in the same vicinity. Much of the southern part of the quadrangle is underlain by Miocene basalt flows. Pleistocene depusite include an extensive blanket of loess in the south and southwest parts of the quadrengle, thick lake deposits of sand and gravel formed from glacial outwash along the valley of the Spokane River, and glacial moraines along the northeast side of the river. Recent olluvium has been deposited in the stream valleys.

The Precambrian and overlying Cambrimn rocks in the northwestern part of the quadrangle are part of the overturned west limb of a northeastward-trending anticline that extends northward for a considerable distance (Campbell and Loofbourow, 1957). Many faults cut the Precambrian rocks. The Paleozoic(?) rocks shown in the southeastern corner of the map appear to be the west limb of a southeastward- or eastward-trending syncline, and are also cut by many faults. The distribution of the Oligocene rocks suggests that their emplacement is controlled by a fault zone along the Spokane River valley and Enterprise Valley. One large normal fault cuts the Oligocene rocks near the center of the quadrangle. No faults or folds were recognized in the younger basalts.

\section{PRICAMBRIAN ROCKS}

The Precambrian and overlying Cambrian rocks in the northern part of the map area form the south end of the magnesite belt, a north-northeast-trending belt of rocks about 30 miles iong. They were first described by Weaver (1920) during his reconnaissance study of Stevens County. Later work by Bennett (1911) and Campbell and Loofbourow (1957) showed the presence of a number of mappable units. Plate 2 shows the stratigraphic units recognized by previous workers.

\section{DEER TRATL GROUP}

TOGO FORMATTON

The oldest rocks in the magnesite belt were named the Togo formation by Campbell and Loofbourow (1957) because of their good exposures near the Togo mine, a few miles north of the Turtle Lake quadrangle. The Togo formation underlies an area of about 10 square miles in the northern part of the Turtle Lake quadrangle. In this area, the Togo is predominantly phyllite, except for the uppermost 600 to 1,600 feet, which is predominantly quartzite.

The base of the phyllite of the Togo formation is not present in the Turtle Lake quadrangle. The phyllite is not resistant to weathering: and forms only small, widely scattered outcrops. Because only a small fraction of the total section present in the quadrangle could be 
measured, the thickness of the Togo was estimated by considering the average dip and the total width of the unit. By this method, the Togo appears to be about 20,000 feet thick. Because the information on which this is based is very fragmentary, the estimated thickness may be considerably different from the true thickness. However, no evidence of thickening as a result of isoclinal folding or repetition by faulting was found.

Bedding in the phyllite typically strikes about N. $10^{\circ}$ E. to N. $20^{\circ}$ E., and dips from about $50^{\circ} \mathrm{W}$. to $60^{\circ}$ (overturned) $\mathrm{E}$. In a few places small-scale folds cause local differences in attitude. An example of one such fold is in a road cut north of Bear Mountain near the center of sec. 30 , T. 29 N., R. 38 E.

The phyllite is predominantly light to dark gray, fine grained, and thin bedded and has well-developed bedding-plane cleavage. Bedding is generally regular and continuous; in a few places, graded bedding can be recognized. The phyllite contains a few beds of quartzite and two beds of dolomitic marble in the vicinity of Spokane Mountain.

The phyllite is made up of quartz, muscovite, biotite, chlorite, feldspar, a few rock fragments, and fine-grained material of unknown composition. Micas are typically oriented with their cleavage planes parallel or subparallel to the bedding, a feature which probably accounts for the generally well-developed bedding-plane cleavage in the rock.

Within a few hundred feet of intrusive rocks, the phyllite is spotted with dark aggregates of fine-grained magnetite or biotite, or both. In places, mica-rich beds and mica-poor beds alternate. Nearer the Loon Lake granite dark-gray andalusite porphyroblasts as much as an inch long are present. Most of the porphyroblasts are extremely poikilitic. Cordierite is present locally. Within a few tens of feet of intrusive rocks the phyllite grades into a schist in which the quartz and mica are coarser grained. No material appears to have been added to the Togo from the intrusion except in a few places within a few feet of the contact, where very fine-grained tourmaline was formed.

Carbonate rock in the Togo has been extensively metamorphosed. A lens of carbonate rock on the south side of Spokane Mountain now consists of diopside, wollastonite, sphene, quartz, magnetite, muscovite, epidote, and garnet, together with coarse calcite in places. A similar carbonate lens about a mile south of the Midnite mine contains gehlenite.

The upper part of the Togo formation is quartzite from 600 to 1,600 feet thick. The contact between the quartzite and the underlying phyllite is gradational through a thickness of about 50 feet. The quartzite crops out continuously along the erest of the southwest-trending ridge west of Sand Creek in sec. 4, T. 28 N., R. 37 E., and sec. 34, 
T. 29 N., R. 37 E. From sec. 34 to the north edge of the quadrangle, it forms only small widely separated outcrops.

The quartzite is typically massive, moderately well cemented, medium grained, poorly sorted, and poorly bedded. Cross bedding is sparse. The color of the freshly broken rock ranges from light gray through shades of greenish gray and reddish brown: weathered surfaces are generally brown or grayish brown. The massive quartzite is nearly pure quartz, but in places it contains a few thin beds or layers of greenish slaty material, rarely more than an inch thick. The slaty material is very fine grained and well sorted. Bedding strikes $\mathrm{N} .10^{\circ}$ to $20^{\circ} \mathrm{E}$, and dips from about $70^{\circ} \mathrm{W}$. to $80^{\circ}$ (overturned) E. The rock appears to have undergone little metamorphism ; the only apparent change is the recrystallization of the quartz.

\section{EDNA DOLOMITE}

The Edna dolomite conformably overlies the Togo formation in a northeast-trending belt in sec. 4, T. 28 N., R. 37 E., and secs. 34, 27 , and 22 , T. 29 N., R. $37 \mathrm{E}$. At the north end of the quadrangle, the Edna consists, from bottom to top, of dolomite, quartzite, slate, and dolomite. The slate and quartzite pinch out to the south, and within $1 \frac{1}{2}$ miles only the dolomite is present. For a short distance the dolomite makes up the entire section. Near the south end of the exposed part of the Edna dolomite, a quarzite layer is again present.

Thickness of the individual units (except the quartzite) and for the Edna as a whole could not be measured. Caluculated thicknesses are: slaty layer, 0 to 400 feet; quartzite, 0 to 25 feet; dolomite, 1,300 to 2,200 feet. The formation as a whole ranges from 1,300 feet thick at the south to 2,500 feet at the north.

The dolomite is poorly exposed, and only a few small, widely scattered outcrops were found. The exposed beds are typically fine grained, poorly bedded, light yellowish gray to almost black, ferruginous and calcareous dolomite. Locally they are thin bedded, and the bedding is considerably contorted on a small scale in a few places. Residual soils formed from the dolomite are characteristically deep red or reddish brown, and in many places the color of the soil was used to locate approximate formation boundaries. In some places the residual soil over the dolomite contains abundant small fragments of thin, fine-grained, brown to green slaty material, presumably from thin slaty beds in the dolomite. In a few places the dolomite has been slightly recrystallized; otherwise it appears virtually unmetamorphosed.

The quartzite layer is discontinuous and pinches out in the south half of sec. 27, T. 39 N., R. 37 E., and at the south edge of sec.33. It overlies the dolomite and is overlain by the slate at the north end and by the dolomite at the south end of its outcrop belt. For most of its 
length the quartzite is massive, very poorly bedded, moderately well sorted, medium grained, whitish to reddish gray, and relatively pure. The quartzite characteristically contains many randomly trending white quartz veins an inch to a foot thick. Throughout most of its exposures the quartzite forms good out crops, a characteristic that is in marked contrast to the dolomite.

The slaty layer in the Edna is present along a strike length of about $1 \frac{1}{2}$ miles at the north end of the quadrangle, where it overlies the quartzite and underlies the dolomite. The unit does not extend south of the southwestern part of sec. 27, T. 29 N., R. 37 E. It is typically a dark-gray to black, fine-grained, locally siliceous rock that is dominantly massive, but contains thin-bedded facies in most outcrops. In some places it has well-developed bedding-plane cleavage. Some of the rock could be called argillite; other parts are more properly termed slate. Outcrops are numerous on the side of a steep slope within onehalf mile of the north edge of the quadrangle, where the resistant quartzite member forms the crest of the ridge. The slate has undergone only low-grade metamorphism.

\section{McHALE SLATE}

The McHale slate conformably overlies the Edna dolomite, and forms a northeast-trending belt about $2 \frac{1}{2}$ miles long. Its average strike is about $\mathrm{N}$., $20^{\circ} \mathrm{E}$, and its dip ranges from $80^{\circ} \mathrm{W}$. to $80^{\circ}$ (overturned) E. Its calculated thickness ranges from 2,400 feet at the north end of the belt to 750 feet at the south end, where it has been thinned as a result of pre-Early Cambrian erosion.

Much of the McHale is very fine grained, thin bedded, and brownish to greenish gray and has well-developed slaty cleavage. Except for development of slaty cleavage, it has undergone very little metamorphism. The cleavage in the McHale dips eastward at a smaller angle than the bedding, and strikes $5^{\circ}$ to $50^{\circ} \mathrm{W}$. of the strike of the bedding. Locally the.McHale is strikingly banded; the bands are beds $1 / 2$ inch to $1 / 16$ inch thick that are alternately light greenish tan and dark green or greenish brown. In some places, however, the slate is poorly bedded. Weathered outcrops of the McHale are dark grayish brown. The $\mathrm{McHale}$ forms good outcrops along the ridge north of the Orazada mine, in secs. 22 and 27, T. 29 N., R. 37 E., and at the fork of Orazada Creek, in sec. 33, T. 29 N., R. 37 E. Elsewhere, outcrops are sparse or absent. In some places, as at the headwaters of Ferguson Creek, the $\mathrm{McHale}$ is covered by a reddish-brown residual soil that is very nearly the same color as the residual soil formed by the Edna dolomite, and as neither the Edna nor the McHale crops out along the upper reaches of Ferguson Creek, the contact between the two formations is difficult to locate. 
STENSGAR DOIOMITE

The Stensgar dolomite conformably o verlies the McHale slate north of the Turtle Lake quadrangle (Campbell and Loofbourow, 1957). No exposures of the Stensgar were found in the Turtle Lake quadrangle, but its presence in one small area is inferred on the basis of its distribution immediately to the north.

In an area $1 / 4$ to $1 / 2$ mile north of the Turtle Lake quadrangle, rocks believed to be upper part of the McHale slate, the Stensgar dolomite, and the lower few hundred feet of the overlying formation, the Addy quartzite, are exposed. In that area the upper part of the McHale contains a few calcareous to dolomitic beds about an inch thick, and these carbonate beds become thicker and more abundant closer to the top of the formation, forming as much as 55 to 60 percent of the rock. Above this, the rock changes abruptly to thin-bedded light-gray dolomite believed to be the Stensgar, which here appears to be about 400 feet thick. Overlying the dolomite is the Addy quartzite.

The noncarbonate-bearing parts of the $\mathrm{McHale}$ form conspicuous outcrops along the crest and west face of the ridge thet runs southwest and northeast from the Orazada mine in sec $27, T .29$ N., R. $37 \mathrm{E}$. To the west, the Addy quartzite also forms prominent, wellexposed outcrops along a southwest-trending belt. The Stensgar generally crops out only along the sides of steep hills capped by more resistant formations, as in the area immediately north of the Turtle Lake quadrangle. In the quadrangle, however, the area believed to be occupied by the Stensgar forms the floor of a small valley. The valley floor is relatively flat and covered with a heavy growth of small trees and brush. No outcrops of any kind are present. The east and west sides of the valley are formed by McHale slate and Addy quartzite, respectively. The valley narrows and steepens to the south, and about $1 \frac{1}{2}$ miles south of the north edge of the quadrangle, the McHale and Addy can be seen in contact. The narrow, wedge-shaped area of no outcrops that lies between the exposures of Addy and McHale is the area believed to be underlain by the Stensgar dolomite.

As the result of mapping in the Hunters quadrangle completed since this manuscript was written, another interpretation of the geology of this area is suggested by A. B. Campbell (oral communication, 1962). He suggests that much of the slate considered above to be McHale is actually slate in the Edna dolomite and that the thinbedded light-grey dolomite is the upper part of the Edna dolomite. Campbell believes that the McHale slate underlies the covered area in the small valley and that only a very thin remnant of Stensgar dolomite extends into the Turtle Lake quadrangle. 
GREENSTONE

Small, scattered dikes, sills, and irregular bodies of greenstone cut Precambrian rocks in many places in the Turtle Lake quadrangle. More than thirty intrusive bodies were found, but only a few were large enough to be shown at the scale of the map.

The greenstone is typically a dark-green, fine-grained, equigranular rock that weathers to a rusty brown and forms few outcrops. In many places it has been cut by randomly oriented shear zones, and where shearing has been intense, foliation has developed parallel to the plane of shearing. The dikes and sills are cut by a few joints, which generally are parallel to the joints in the surrounding country rock. Many of the intrusive bodies are less than 100 feet long, only 5 to 20 feet thick, and are parallel to the bedding of the enclosing rocks. Metamorphism of the country rock as a result of these bodies is confined to a zone generally only a few inches from their contact, where the host rock has become a hornfels.

The greenstone was originally a mafic igneous rock. It contains from 60 to 80 percent hornblende, about 20 to 25 percent plagioclase, and locally as much as 3 percent pyrite, together with small amounts of biotite, magnetite, and sphene. It has undergone the same lowgrade regional metamorphism as the enclosing metasedimentary rocks, and this metamorphism is evident under the microscope. The hornblende is typically partly altered to chlorite or locally to chlorite and biotite, magnetite or ilmenite. Plagioclase is also commonly somewhat altered to fine-grained aggregates of feldspar and sericite. Calcite is present locally. Some of the greenstone originally had a porphyritic texture, with abundant hornblende phenocrysts $1 / 2 \mathrm{~mm}$ to $2 \mathrm{~mm}$ long in a groundmass of plagioclase and hornblende. Metamorphism, which included some shearing and recrystallization, has given some of the rock a cataclastic texture, with only bent and ragged remnants of phenocrysts in a few places.

The age of the greenstone is not known. Campbell and Loofbourow (1957) report that in the magnesite belt to the north, similar greenstone dikes are confined to rocks of Precambrian age, as they are in the Turtle Lake quadrangle. This observation, together with the similarity in composition between the intrusive greenstone and the greenstone of the Huckleberry formation, the youngest known Precambrian formation in the magnesite belt, led Campbell and Loofbourow to assign the intrusive dikes to the Precambrian. Thus, the greenstone in the Turtle Lake quadrangle is also considered to be Precambrian in age. 


\section{CAMBRIAN ROCKS}

ADDY QUARTZITE

The Addy quartzite unconformably overlies the Precambrian rocks in the Turtle Lake quadrangle. The Addy forms a belt extending from the north edge of the quadrangle southward for about $2 \frac{1}{2}$ miles, where it is covered by flows of Gerome andesite. It forms prominent outcrops on both sides of the Spokane River, near the west boundary of the quadrangle, and covers nearly half a square mile on the top of Lilienthal Mountain, in secs. 22 and 23, T. 28 N., R. 36 E.

Weaver (1920) and Bennett (1941) describe the Addy as dominantly a relatively pure quartzite, but containing subordinate amounts of quartz-mica schist. In the Turtle Lake quadrangle, the Addy is dominantly a quartzite but also contains layers of argillite. Near the north margin of the Turtle Lake quadrangle the Addy consists of three quartzite layers and two argillite layers. The lowest quartzite layer, which forms the base of the formation, is approximately 2,600 feet thick; above it is an argillite layer about 700 feet thick, then in succession, quartzite about 150 feet thick, argillite 350 feet thick, and quartzite about 125 feet thick. Total thickness is about 3,900 feet. On Lilienthal Mountain about 5 miles to the southwest, an incomplete section, consisting of only the lower one-third to one-half of the formation, contains two quartzite layers and two layers that range from phyllite to impure quartzite in composition.

The quartzite layers are predominantly medium grained, moderately to well sorted, white, light yellowish gray, or reddish to purplish brown, massive, and well cemented. The lower (eastern) 100 to 200 feet of the basal quartzite laver lacks prominent sedimentary structures but the rest of the quartzite contains excellent graded bedding and graded crossbedding. Ripple marks are present in a few places. The quartzite is generally pure but locally contains a few widely scattered grains of feldspar and garnet and in places a small amount of iron oxide. All three quartzite layers north of the river form prominent outcrops throughout most of their length.

The argillite layers are predominantly fine-grained, laminated, thin-bedded, green to brown rocks, which locally have good to excellent bedding-plane cleavage. In places they contain thin, discontinuous lenses of quartzite.

No fossils were found in the Addy in the Turtle Lake quadrangle, but Okulitch (1951) identified Early Cambrian fossils in the Addy about 25 miles to the north.

OLD DOMINION LIMESTONE OF WEAVER, 1920

Weaver's Old Dominion limestone conformably overlies the Addy quartzite. In the Turtle Lake quadrangle the Old Dominion has an 
exposed thickness of about 4,400 feet. Its top is covered by flows of Gerome andesite.

The Old Dominion is fine- to coarse-grained limestone and ranges from white in some of the coarse-grained, recrystallized rock to black in some of the fine-grained rock. In most places it contains thin, easily recognized beds, but in some exposures bedding is difficult or impossible to recognize. Outcrops, which are scarce, are weathered to a gray or yellowish gray. The Old Dominion limestone strikes about N. $20^{\circ} \mathrm{E}$. and dips about $70^{\circ} \mathrm{W}$., parallel to the underlying Addy quartzite. A few hundred feet north of the quadrangle the Old Dominion is in contact with the Loon Lake granite. Within 1,000 feet of their contact, the Old Dominion is extensively recrystallized to a nearly pure calcite marble, with grains as much as $2 \mathrm{~mm}$ in diameter. A few beds 5 to 12 inches thick consist of 1 - to 3 -inch aggregates of radiating needles of tremolite.

\section{CAMBRIAN-PRECAMBRIAN UNCONFORMITY}

The Cambrian-Precambrian boundary in the Turtle Lake quadrangle is an unconformity. Little information on the nature of this boundary was previously available in most parts of northeastern Washington, principally because of poor exposure of late Precambrian and Early Cambrian rocks. Critical exposures are present in the Turtle Lake quadrangle, however.

The gap in the stratigraphic section is greatest at Lilienthal Mountain, in sec. 23, T. 28 N., R. 36 E., where Addy quartzite of Early Cambrian age unconformably overlies the Togo formation of Precambrian age with an angular discordance of about $15^{\circ}$ (pl. 1). About 4 miles to the northeast, on the north side of the Spokane River, the Addy unconformably overlies the younger McHale slate, also of Precambrian age. The intervening area is occupied by younger rocks. At the north edge of the Turtle Lake quadrangle, the Addy quartzite unconformably overlies the Stensgar dolomite, the next younger Precambrian formation. Eight miles north of the Turtle Lake quadrangle, along the Hunters-Springdale road, the Addy quartzite unconformably overlies the Huckleberry formation, the youngest formation of Precambrian age known in southern Stevens County. In the 16-mile interval between the Hunters-Springdale road and Lilienthal Mountain, the stratigraphic section has been thinned a maximum of 8,600 feet. This represents considerably more pre-Early Cambrian erosion than has been recognized previously in northeastern Washington.

Recognition of the extent of pre-Early Cambrian erosion in the Turtle Lake quadrangle hinges on the identity of the thick quartzite that overlies the Stensgar and McHale in the northern part, and 
the quartzite of the Togo formation in the westem part of the quadrangle. Campbell and Loofbourow (1957) had proviously identified the quartzite as Buffalo Hump formation of Precambrian age (fig. 2).

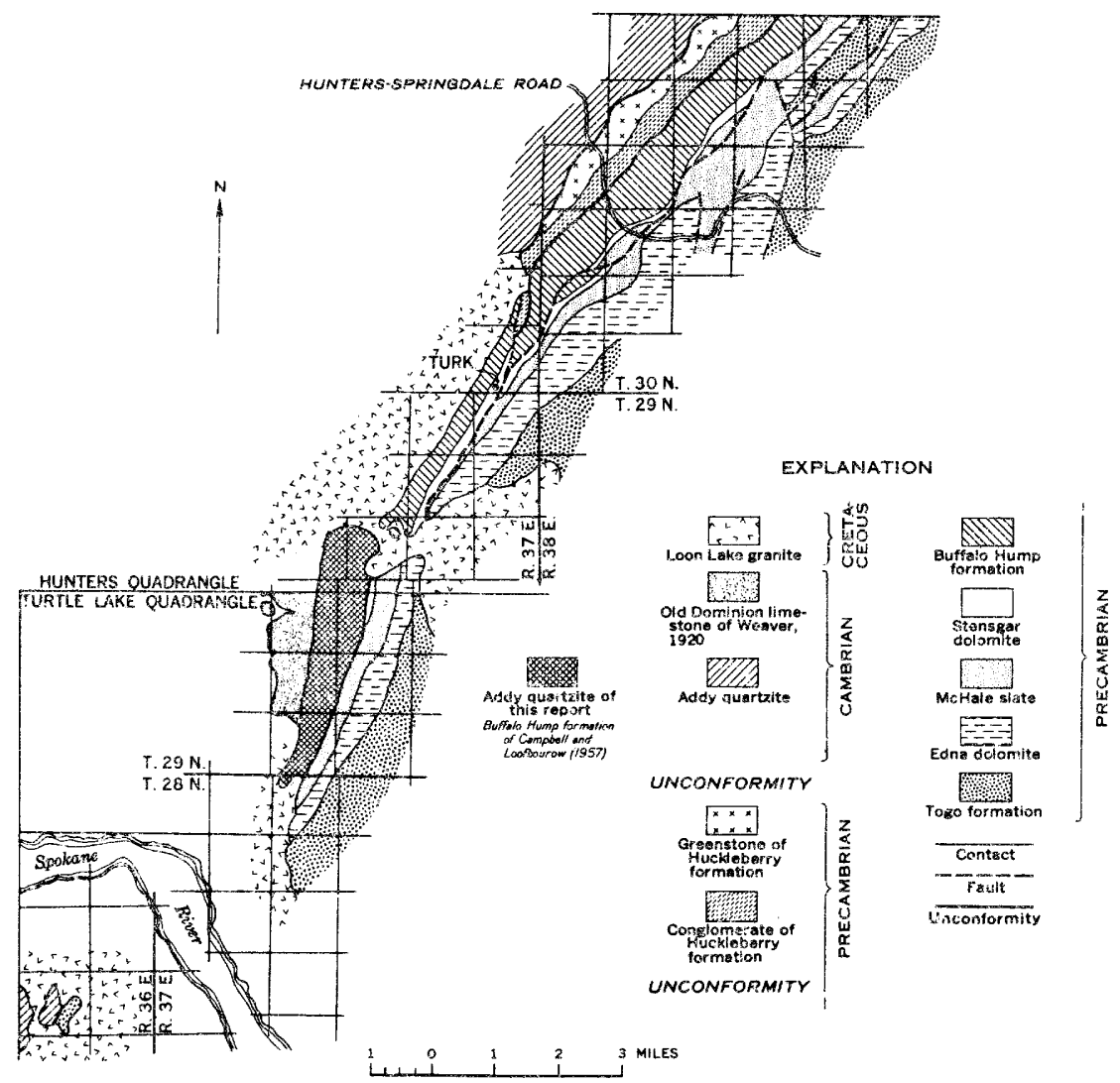

FIGURE 2,- Generalized geologic map of the southern part of the magnesite belt, Stevens and Lincoln Counties, Wash. (In part after Campbell and Loofbourow, 1957.)

However, west of the Orazada mine, in an area which they did not map, the writers found that the quartzite is overlain, with apparent conformity, by a very thick limestone formation. The limestone is considerably thicker than any Precambrian carbonate formations in Stevens County. The only thick limestone formation known in the area is the Old Dominion limestone of Weaver, of Early Cambrian age, which overlies the Addy quartzite farther north in Stevens County. The apparently conformable relation between the limestone and the underlying quartzite in the Turtle Lake quadrangle makes it probable that the quartzite is the Lower Cambrian Addy, rather than the Precambrian Buffalo Hump as Campbell and Loofbourow supposed. 
CORRELATION OF THE PRBCAMBRIAN AND CAMBRIAN ROCKS

The amount of pre-Early Cambrian erosior in the Turtle Lake quadrangle is in marked contrast to the amount of erosion recognized in adjacent areas in Washington and in parts of southern British Columbia. This contrast in pre-Cambrian geologic history raises the question as to the age and possible correlatives of the Precambrian rocks in the Turtle Lake quadrangle.

According to C. P. Ross (written communication, 1952), the term "Belt series" has come to be generally accepted for sedimentary rocks in Montana. northern Idaho, and adjacent parts of Washington that are older than recognized Cambrian strata and younger than rocks of Archean type. By this definition, the rocks of the magnesite belt that underlie the Addy quartzite are typical representatives of the Belt series.

A distance of about 20 miles separates the north limit of Campbell and Loofbourow's mapping in the magnesite belt from the southwest corner of the Metaline quadrangle, which was mapped by Park and Cannon (1943). This gap in available geologic information is a handicap to precise correlation of the two areas, but the stratigraphy of the areas is so similar in several respects that the correlation proposed below appears highly plausible. This correlation is summarized in a highly generalized and diagrammatic way in figure 3 .

The similarity between the Huckleberry greenstone and the conglomerate in the Huckleberry formation of the magnesite belt, and the Leola volcanics and Shedroof conglomerate of the Metaline quadrangle is so great that their correlation is immediately suspected. In each area a distinctive conglomerate is overlain by material consisting mainly of altered mafic volcanic rocks. In both areas, an unconformity is present at the base of the conglomerate and another is present at the top of the volcanic unit. In each area, rocks beneath the lower unconformity (the Deer Trail group of Campbell and Loofbourow, and the Priest River group of Park and Cannon) strongly resemble Belt rocks of adjacent areas in composition and degree of metamorphism. In both areas, Lower Cambrian rocks unconformably overlie the volcanic rocks. The only significant difference between the two areas is that in the Metaline quadrangle a nonfossiliferous unit consisting mainly of fine clastic material (the Monk formation) is the oldest formation thought to be of Cambrian age, and it is in turn overlain by the fossiliferous Lower Cambrian Gypsy quartzite; whereas in the magnesite belt the oldest Lower Cambrian unit is the fossiliferous Addy quartzite.

North of the Metaline quadrangle, in the Salmo area of British Columbia, Walker (1934) and Little (1950) found the Precambrian and Cambrian stratigraphy very similar to that of the Metaline 
SW LILIENTHAL NORTH EDGE OF
MOUNTAIN TURTLE LAKE TURTLE LAKE

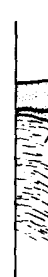

NORTH END OF
MAGNESITE BELT
INTERNATIONAL BOUNDARY

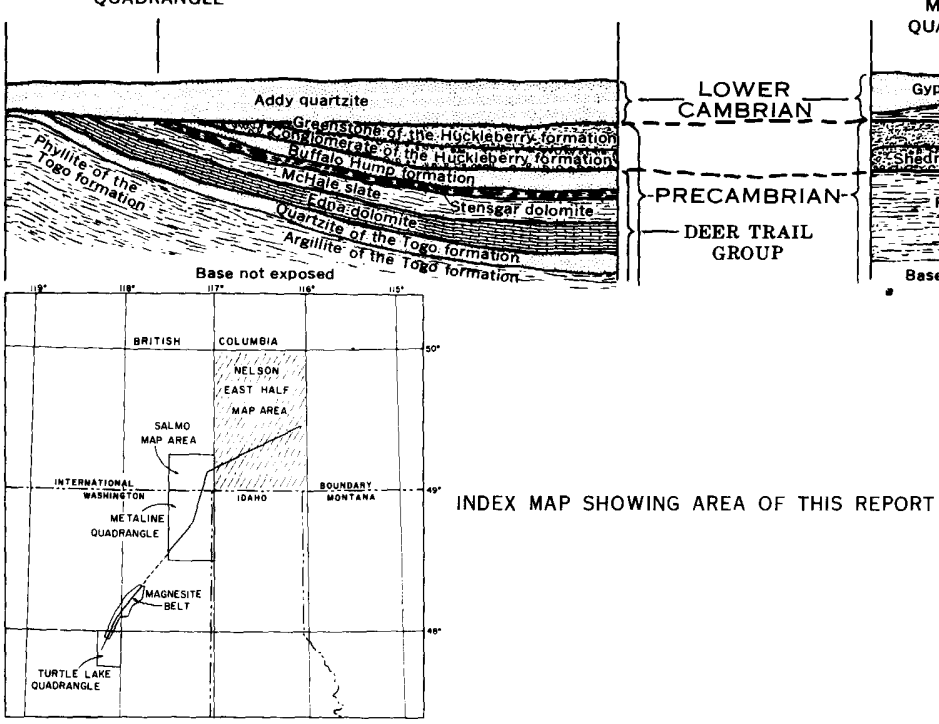

FigURE 3.-Generalized correlation diagram showing possible stratigraphic relations of Lower Cambrian and Precambrian rocks in parts of northeastern Washington and southeastern British Columbia. Rock units above the Lower Cambrian quartzite are not shown.

Data derived partly from Campbell and Loofbourow (Mag-

nesite Bitt-1957); Park and Cannon (Metaline quadrangle-

1941); Reesor in Gill (Proterozoic in Canada-1957)

Vertical Scaie Exaggerated 
quadrangle. A Lower Cambrian quartzite (the Quartzite Range formation) is the oldest fossiliferous Cambrian unit. It conformably overlies a thick sequence of clastic sediments which, like the Monk formation of the Metaline area, contains no fossils. Little subdivided the nonfossiliferous rocks into two formations. He considered the lower formation equivalent to the Monk formation of the Metaline quadrangle, and applied the same name to it. He named the upper unit the Three Sisters formation. The Monk formation conformably overlies the Irene volcanics, the equivalent of the Leola volcanics of the Metaline quadrangle, and the Irene in turn conformably overlies the Toby conglomerate. the equivalent of the Shedroof conglomerate in the Metaline quadrangle. The Toby conglomerate is the oldest formation recognized in the Salmo map area.

The Nelson map area, east half, lies immediately east of the Salmo map area. Rice (1941) described a number of units in the Nelson map area that can be correlated with formations in the Salmo and Metaline areas. The oldest rocks, his Upper and Lower Purcell groups, are Belt in age, and extend southwest through the northwestern corner of Idaho into the Metaline quadrangle, where Park and Cannon called them Priest River group. Unconformably above the Upper Purcell is a sequence that includes the Toby conglomerate, Irene volcanics, and Monk formation, which extend into the Nelson map area from the Salmo map area. The Three Sisters formation and the Quartzite Range formation of the Salmo map area also extend into the Nelson map area, where they are named the Horsethief Creek series and the Hamil series, respectively. Rice considered this entire group of sedimentary rocks above the Upper Purcell group to be of Precambrian (Windermere) age, but Reesor (1957) believed the Hamil series is Early Cambrian in age. The Hamil series is shown as Lower Cambrian in figure 4. It is an extension of the Quartzite Range formation of the Salmo map area. Farther east in the Nelson map area, east half, Lower Cambrian quartzite (the Cranbrook formation) unconformably overlies rocks of the Lower Purcell group.

The geologic history and stratigraphic relations in the Turtle Lake quadrangle, the central part of the magnesite belt, the Metaline quadrangle, the Salmo map area, and the Nelson map area, east half, can be summarized as follows:

1. The entire region was a basin of deposition during Belt (Purcell and its equivalents) time, when the Deer Trail series, the Priest River group, and the Purcell group were deposited. These rocks may or may not be exact time equivalents in their respective areas.

2. A periuc of erosion of unknown length followed the deposition of Belt (Purcell-Priest River-Deer Trail) rocks everywhere in the region. This period may well have been of different duration in 
different places, but probably was at least in part contemporaneous everywhere in the region.

3. After the period of erosion, sedimentation was renewed with the deposition of a conglomerate-the Huckleberry-Shedroof-Toby-which may have covered the entire region with the exception of the eastern part of the Nelson map area (Reesor, 1957, p. 164-165). The conglomerate in turn was overlain by a unit composed mainly of mafic volcanic rocks-the Huckleberry greenstone-Leola-Irene volcanics. After deposition of the volcanic rocks, the northeastern and southwestern parts of the area were again uplifted and eroded; simultaneously, between the two areas of uplift, additional sediments, consisting mainly of clastic material, were laid down in parts of the Nelson and Salmo map areas. The basin of sedimentation gradually expanded southward into the Metaline quadrangle (the Monk formation) in late Precambrian or Early Cambrian time.

4. In Early Cambrian time a fossiliferous sandstone (now quartzite) was laid down over the entire area-the Addy-Gypsy-Quartzite RangeHamil-Cranbrook. It lies conformably upon older rocks in the Salmo map area and parts of the Metaline quadrangle and Nelson map area, and is unconformable or disconformable on older rocks elsewhere.

5. Little is known of the subsequent geologic history of the southern part of the region (the magnesite belt) until the period of orogeny that folded the entire sequence of sediments. This period, possibly the Laramide orogeny, culminated with the intrusion of the Loon Lake granite and related rocks of probable Cretaceous age.

Precise correlation of the rocks that lie between the Toby conglomerate and the oldest recognizable Lower Cambrian rocks is not possible. Some Canadian workers have assigned the entire sequence to the Windermere series, which they consider to be post-Belt and pre-Cambrian in age. Other workers suggest that some of the upper Windermere is Early Cambrian in age, and some of the lower Windermere is Belt. The answers to these uncertainties are obviously far outside the scope of this report. The principal purposes for the correlations suggested above and in figure 3 are to point out the apparent geologic relations between the Turtle Lake quadrangle and adjacent areas, particularly with reference to the limits, distribution, and approximate time relations of the Belt rocks.

\section{PALEOZOIC(P) ROCKS}

The Paleozoic(?) rocks make up a metamorphic complex exposed in the southeastern part of the quadrangle. The complex is separated from the Precambrian and Cambrian rocks to the north by about 6 miles of Loon Lake granite; to the south and east the complex is com- 
pletely covered by Columbia River basalt and Palouse formation within less than 1 mile beyond the boundaries of the quadrangle.

The complex includes mica-bearing quartzite, calc-silicate hornfels, calc-silicate marble, and quartzose phyllite and fine-grained muscovite schist. The bedding in the rocks strikes generally north to northwest and dips steeply to the east and northeast. The stratigraphic relation of the quartzite to the other metamorphic rocks is not known because they were not observed in contact. The quartize is about 1 mile west of the nearest outcrop of calc-silicate hornfels; the intervening area is covered by Pleistocene sand deposits. The only suggestion of relative age is that the quartzite dips steeply eastward as do the other rocks in the complex; thus, possibly the quartzite dips under the calc-silicate hornfels and is older. The calc-silicate hornfels underlies the interbedded calc-silicate marble and phyllite sequence, but the actual contact is everywhere covered by soil and vegetation.

\section{QUARTZITE}

The quartzite is exposed only in the vicinity of the Lowley Lease in sec. 13 , T. 27 N., R. 37 E., where it forms low outcrops that stand above the Pleistocene sand deposits. The rock is fine to medium grained and generally impure. The color ranges from dark gray to light brown or purple. The bedding ranges in thickness from less than $1 / 4$ inch to more than 2 feet; crossbedding is sparse. The beds have a general north to northeast strike and dip steeply to the east. The quartzite is several hundred feet thick, but neither the top nor the bottom of the formation was observed. The contact with the granodiorite is a fault where it was exposed in bulldozed trenches; everywhere else the contact is covered.

Microscopic examination indicates that the quartz in the rock occurs as grains $0.2 \mathrm{~mm}$ to $0.4 \mathrm{~mm}$ in diameter. The quartz appears to have been completely recrystallized; the grains have uniform extinction, and no evidence of overgrowths on clastic grains was observed. Brown biotite and muscovite commonly occur as small, irregular, interstitial grains; in a few sections there is a slight tendency for preferred crientation of some of the mica grains. The mica also occurs as randomly oriented grains in thin, irregular layers from $0.1 \mathrm{~mm}$ to $1 \mathrm{~mm}$ in thickness. The amount of mica in the quartzite ranges considerably; it is commonly about 10 percent of the rock, but in some beds it makes up nearly 25 percent of the rock. The ratio of biotite to muscovite also ranges considerably, but biotite exceeds muscovite in amount. A few of the mica plates are partly replaced by a lightgreenish faintly pleochroic chlorite.

In bulldozer trenches at the Lowley Lease near the contact with the granodiorite, the rock contains sporadic small, irregular aggre- 
gates of randomly oriented, ragged grains of talc and small euhedral crystals of anthophyllite. The same rock contains abundant serpentine as a filling between quartz grains. A few very small and irregularly shaped grains of light-brown biotite are present in the rock. This rock and the adjacent granodiorite are cut by a fault zone about 5 to 30 feet thick that approximately follows the contact in the bulldozed area. Uranium minerals and pyrite have been deposited locally along this zone.

The mineralogy of the quartzite unit indicates that it was probably originally an argillaceous sandstone, and that the amount of argillaceous material varied considerably from one bed to another. The mica has probably been formed by recrystallization of an argillaceous matrix that surrounded the original quartz grains. Regional relations indicate that the argillaceous sandstone underwent low-grade regional metamorphism. The only suggestion of this metamorphism in the quartzite is the slight tendency for preferred orientation of some of the mica which is probably mimetic, and the thin irregular layers of mica. The layers of mica might have been concentrations of sericite and chlorite along $s$ planes in a phyllitic or slightly schistose quartzite. Recrystallization of the rock during static thermal metamorphism is indicated by the randomly oriented mica. The presence of biotite and the absence of chlorite (except the small amount replacing biotite and thereby indicating slight retrograde metamorphism) indicates that the rock probably was metamorphosed under the pressuretemperature conditions of the hornblende hornfels facies of Fyfe, Turner, and Verhoogen (1958, p. 206).

\section{HORNFELS}

Calc-silicate hornfels forms many bold outcrops in the areas northwest of Cayuse Mountain and south of the Spokane River. The rock is very hard and strikingly color-banded. The bands vary from white through shades of green to brown and range in thickness from less than an inch to several inches. The banding tends to be regular and is parallel to original bedding wherever the bedding could be be determined. Locally in the hornfels there are thin beds of marble and of fine-grained, mica-bearing quartzite generally only a few inches thick. The beds of marble appear to be more common in the upper part of the unit.

South of the Spokane River, the bedding and regular color banding strike generally northwest and commonly dip from $40^{\circ}$ to $70^{\circ} \mathrm{NE}$. Dips as low as $25^{\circ}$ and as high as $90^{\circ}$ were observed, and in a few places the beds are apparently overturned and dip $80^{\circ} \mathrm{SW}$. Northwest of Cayuse Mountain the layering strikes northeast and dips steeply to the southeast-commonly $65^{\circ}$ to $80^{\circ}$. 
The lower contact of the calc-silicate hornfels is covered by sand. On Cayuse Mountain the upper contact was placed approximately at the base of a unit consisting predominantly of marble. Although this contact is covered by soil and vegetation, it can be located within a few tens of feet. The relations south of the river are not so clear because of the thick soil and tree cover and because of the many sills and dikes of Gerome andesite cutting the metamorphic rocks in the vicinity of this contact. The intrusive rocks are more resistant to erosion than the marble and phyllite, and andesite float covers much of the slope in the vicinity of the contact.

The actual thickness of the hornfels unit is not know, but based on an average attitude and width of exposure of the unit, the thickness appears to be on the order of a few thousand feet.

Microscopic examination indicates that the rocks of this unit consist largely of quartz and calc-silicate minerals and commonly contain muscovite, biotite, untwinned plagioclase, and potassium feldspar. The calc-silicate minerals include diopsidic pyroxene, amphiboles, epidote, and clinozoisite. The relative abundance of the calc-silicate minerals varies in different sections; some sections contain all of the calc-silicate minerals listed, but others contain only amphiboles or diopsidic pyroxene and epidote.

The brownish layers commonly consist of small grains of quartz, potassium feldspar, and untwinned plagioclase, plates of biotite about $0.02 \mathrm{~mm}$ long, and a few large poikiloblastic grains of actinolitic hornblende. Many of the grains of quartz are slightly elongated parallel to the layering in the rock, and the biotite plates are commonly also alined parallel to the layering; however, in some beds much of the biotite is randomly oriented. The large grains of amphibole are randomly oriented.

The greenish layers consist of quartz, untwinned plagioclase, epidote, and clinozoisite; some have diopsidic pyroxene and tremolitic amphibole. Sparse, small, irregular grains of calcite also occur in some of the greenish layers. The epidote, clinozoisite, and diopsidic pyroxene appear to be contemporaneous. The tremolitic amphibole is alined about parallel to the layering and appears to have formed earlier than the other calc-silicate minerals. Commonly cummingtonitic hornblende occurs in a thin zone about $0.2 \mathrm{~mm}$ wide at the compositional interface between the different layers. The thinness of this zone indicates that transfer of elements between the compositional layers took place on only a very small scale.

The markedly different mineral assemblages in different layers of the hornfels unit indicate a considerable range in original composition. Layers rich in biotite and hornblendic amphibole were probably 
originally argillaceous dolomite; layers rich in epidote, diopsidic pyroxene, and tremolitic amphibole were originally largely sandy dolomite.

The parallel alinement of small biotite plates in some layers, the alinement of tremolitic amphibole, and the alinement of the elongated quartz grains strongly suggest that the original sedimentary rocks underwent regional metamorphism. Biotite and tremolitic amphiboles are probabiy mimetic after alined minerals (perhøps chlorite or sericite of the earlier regional metamorphism), as suggested by their preferred orientation. Calc-silicate minerals are clearly later than the biotite and tremolitic amphiboles, as shown by their random orientation and replacement textures. The later, randomly oriented minerals suggest that a period of static thermal metamorphism followed the regional metamorphism. The apparently stable assemblage of diopsidic pyroxene, epidote, and clinozoisite, as well as the composition of the plagioclase $\left(\mathrm{An}_{30-35}\right)$, indicate that the rocks were metamorphosed under hornblende hornfels facies conditions. The presence of rocks of the hornblende hornfels facies several miles from the exposed contacts between the metamorphic complex and the Loon Lake granite suggests that the granitic rocks underlie the complex at a rather shallow depth throughout much of the area.

\section{MARELE AND PHYLZTTE}

Overlying the hornfels is a sequence of marble and phyllite. It is best exposed on Cayuse Mouritain. In this area the rocks are cut by three large steeply dipping faults of unknown displacement and are best exposed between the western and middle faults (pl. 1). There, the sequence consists of a marble unit overlain by a phyllite unit, a second marble, a second phyllite, and a third marble. The phyllite may be lenticular because the upper phyllite unit appears to thin toward the southeast before it is cut off by the middle fault on Cayuse Mountain. South of the Spokane River, individual marble and phyllite units could not be mapped because of poor exposures, and the entire sequence was therefore mapped as undifferentiated.

Locally the bedding in the marble layers is extremely contorted, but generally the attitude of the bedding is consistent over large areas and is parallel to the bedding in the phyllite. Near the southeastern exposures of the sequence, the bedding generally strikes northwest and dips steeply to the northeast. Near the west end of Cayuse Mountain the strike of the bedding swings to the north and northeast.

The marble generally forms isolated outcrops. It is thin bedded to massive and fine to coarse grained. The grain size is commonly different in adjacent beds and is markedly coarser at a few places along the contact with the granodiorite. The color of the rock 
ranges from white to dark gray, and composition ranges from calcsilicate to almost pure marble. The rocks consist predominantly of calcite but commonly contain diopsidic pyroxene, wollastonite, scapolite, vesuvianite, grossularite, forsterite, serpentine, orthoclıse, and plagioclase (about $\mathrm{An}_{70-30}$ ) in varying amounts.

The mineralogy of this unit indicates that it was probably originally a slightly argillaceous sandy dolomite. The amount of impurities in the dolomite varies considerably but is less than in the lower calcsilicate hornfels unit described earlier. The mineral assemblage of the calc-silicate marble indicates that it was metamorphosed under pressure-temperature conditions of the pyroxene hornfels facies. Areal relations indicate that, like the associated rocks, the marble underwent regional metamorphism, but within the marble any evidence of this metamorphism has been destroyed by the later static thermal metamorphism.

The phyllite unit contains rocks varying from quartzose phyllite to fine-grained muscovite schist. It forms scarce, low, rubbly outcrops and is nowhere well exposed. 'The rocks are thin bedded; the schistosity generally parallels the bedding. The rocks are light to dark gray and wenther to a reddish brown. They consist predominantly of fine-grained quartz (usually 60 to 90 percent) and muscovite (usually 10 to 40 percent) and contain minor amounts of tourmaline, zircon, apatite, and magnetite. Some beds contain a small amount of biotite.

Microscopic examination of the rocks of this type from Cayuse Mountain reveals that they are layered, and the relative abundance of muscovite and quartz varies considerably in adjacent layers. The quartz grains are irregular in shape and are commonly slightly elongated parallel to the compositional layering. They show no evidence of cataclasis or overgrowths. The mica ranges considerably in grain size from sericite to muscovite grains $1 \mathrm{~mm}$ long. Most of the mica plates are randomly oriented, particularly the larger ones, but some are alined parallel to the layering. The phyllite on the north slope of Cayuse Mountain in sec. 20 is unusually rich in tourmaline. This tourmaline is brown and forms irregular grains; elsewhere, the tourmaline is faintly bluish green and eubedral. Possibly the abundance of tourmaline on Cayuse Mountain indicates the addition of boron during the intrusion of the granodiorite.

South of the river in sec. $34, T .27$ N., R. 38 E., there are a few small isolated outcrops of fine-grained mica schist consisting of quartz and alined muscovite and including ovoid masses of chlorite and quartz. The chlorite forms very small randomly oriented grains and also coarser grains that are approximately parallel to the alined muscovite plates.

The mineralogy of this rock indicates that it was probably originally an argillaceous, quartzose sedimentary rock. The ratio of quartz 
to argillaceous material varied considerably from one bed to another. The alinement of muscovite suggests that the rocks were regionally metamorphosed. The muscovite may be mimetic after sericite. On Cayuse Mountain the rocks were later thermally metamorphosed under static conditions and much of the mica was recrystallized, producing the randomly oriented grains. Recrystallization was slight south of the river, and the mica is mostly alined parallel to the compositional layering. The masses of chlorite and quartz in the fine-grained mica schist suggest that incipient recrystallization did occur under static thermal metamorphism. Possibly poikilitic porphyroblasts of cordierite were formed; if so, later retrograde metamorphism altered the cordierite, as well as the mica included in the porphyroblasts, completely to chlorite.

No diagnostic minerals indicating the grade of thermal metamorphism are present in this rock type on Cayuse Mountain; however, because the calc-silicate marble was metamorphosed under proxene hornfels facies conditions, it seems likely that the phyllite was metamorphosed under similar conditions. As indicated earlier, this rock type south of the river was only slightly thermally metamorphosed. This suggests that these rocks are farther from the granodiorite contact than most of the complex.

AGE

The age of the original sedimentary rocks of the metamorphic complex is not definitely known, but they predate the Loon Lake granite. No fossils were found in the rocks. The stratigraphic section can not be matched with any part of the Precambrian section farther north in the quadrangle nor with any other known Precambrian rocks north of the quadrangle. The Paleozoic rocks in the region are not well enough known to permit a direct correlation with the units here described, but there is a similarity between these metamorphic rocks and the Addy quartzite and Weaver's Old Dominion limestone. The Addy is generally a clean, vitreous quartzite containing almost no impurities, but in places it does contain beds of argillite and rather impure quartzite. Thus, it is possible that the mica-bearing quartzite near the Lowley Lease could be the Addy. The Old Dominion limestone is commonly a pure limestone or dolomite, but locally it contains a large amount of silt. In the northern part of the Turtle Lake quadrangle the formation is a relatively pure marble, but about 15 miles to the north in the Hunters quadrangle the formation is an argillaceous to sandy limestone and dolomite. In the Hunters quadrangle the impure limestone and dolomite appears to be several thousand feet thick. The similarity in composition between these rocks and the metamorphic rocks in the southeastern part of the 
Turtle Lake quadrangle is apparent; thus, the Turtle Lake rocks are considered to be Paleozoic(?) in age.

\section{CRETACEOUS ROCKS}

\section{LOON LAKE GRANITE}

The Loon Lake granite was named by Weaver (1920, p. 87-89) who stated that it occupied the entire eastern part of Stevens County. He described the formation as being dominantly granitic but including syenite, monzonite, and diorite. This formation is the dominant rock in the Turtle Lake quadrangle.

Five main rock types including granodiorite, porphyritic quartz monzonite, equigranular quartz monzonite, fine-grained equigranular quartz monzonite, and fine-grained quartz monzonite rich in mafic minerals were mapped in the quadrangle. The relative ages of these rock types are in general uncertain, but in at least one small area the granodiorite is slightly older than the adjacent porphyritic quartz monzonite. In sec. 33 , T. 27 N., R. 37 E., small dikes of the quartz monzonite extend into the granodiorite for a few tens of feet. Aplite, alaskite, pegmatite, granite porphyry, and lamprophyre occur as dikes, generally with sharp boundaries, in the granodiorite, porphyritic quartz monzonite, and equigranular quartz monzonite and are definitely younger than the enclosing rocks, although the age difference may not be great.

\section{GRANODIORITE}

Granodiorite underlies much of the southeastern part of the quadrangle and is a massive, medium-grained, and medium-gray rock containing abundant biotite and hornblende relative to the other rocks of the Loon Lake granite. It is very well exposed in glaciated outcropls north of the Spokane River in secs. 15, 21, and 22, T. 27 N., R. 38 E. (fig. 7), and also in sec. 34 , T. 27 N., R. 37 E., south of the river. The granodiorite is deeply weathered along its northwestern contact with the porphyritic quartz monzonite north of the river and does not crop out in this area. This contact was not observed and is mapped mainly on the differences in the soil over the two rock types. The soil over the porphyritic quartz monzonite commonly contains abundant large potassium feldspar crystals and very little biotite, whereas the soil over the granodiorite contains no potassium feldspar crystals and commonly contains abundant small ragged biotite grains. In the stream valley northwest of the Big Smoke mine in sec. 11, T. 27 N., R. 37 E. the contact can be located within a few feet, but no dikes of the porphyritic quartz monzonite were observed cutting the granodiorite similar to those south of the river mentioned earlier. The contact between the granodiorite and the Paleozoic(?) rocks in the vicinity of Cayuse Mountain, and south of the river in the vicinity 
of Harker Canyon is sharp. Although the actual contact was observed in only a few places, it can generally be located within a few feet. The granodiorite is not commonly finer grained near the contact with the older rocks, but in one locality southeast of Cayuse Mountain near the section line between secs. 21 and 28 , the grain size is slightly finer within a few feet of the contact.

Inclusions of the adjacent metamorphic rocks are extremely sparse in the granodiorite and were observed only within a few feet of the contacts with the older rocks. Small irregular masses of mafic-rich granodiorite are common and may be intensely altered inclusions, but this is not certain. Some of the mafic-rich masses have only slightly more hornblende than the surrounding granodiorite, but some are almost entirely hornblende with sparse biotite.

The rock is cut by many small aplite, alaskite, and pegmatite dikes, most of which are too small to be shown on plate 1. A few larger dikes occur along the county road north of Benjamin Lake near the eastern boundary of the quadrangle. In the vicinity of the Lowley Lease the granodiorite is cut by several dikes of granite porphyry.

The granodiorite contains 25 to 30 percent quartz, 35 to 40 percent plagioclase $\left(\mathrm{An}_{40-55}\right), 10$ to 15 percent potassium feldspar, 7 to 15 percent biotite, 7 to 12 percent hornblende, and 1 to 2 percent accessory minerals including sphene, apatite, magnetite, and zircon. The average grain size of the rock is about $3 \mathrm{~mm}$. The plagioclase is subhedral and faintly zoned - the core usually has an anorthite content only a few percent higher than the rims. Albite rims are uncommon and where present adjacent to potassium feldspar grains are very thin. Myrmekite is cornmon along contacts with potassium feldspar. Most of the plagioclase is slightly sericitized, and commonly a few crystals in each section are almost completely altered to sericite. The quartz is anhedral and unstrained. The potassium feldspar is interstitial. Some grains have the typical grid twinning of microcline, but many other grains are untwinned. Hornblende is subhedral to euhedral and is commonly unaltered, but locally some crystals are partly altered to epidote. Many hornblende crystals, some of which are as much as $7 \mathrm{~mm}$ long, contain small plagioclase grains. The biotite is commonly in well formed laths from 2 to $5 \mathrm{~mm}$ long, but in places the rock contains aggregates a few millimeters in diameter made up of randomly oriented small crystals of biotite. Most of the biotite grains contain small crystals of zircon surrounded by dark halos. Locally much of the biotite is partly to completely altered to chlorite.

Chemically the granodiorite differs markedly from the other rocks of the Loon Lake granite. The chemical analysis given in table 1 indicates that the granodiorite is considerably higher in total iron, magnesium, and calcium and lower in total alkalies. 
TABLE 1.-Chemical analyses (in weight percent) and calculated norms of rocks of the Loon Lake granite

\begin{tabular}{|c|c|c|c|c|c|c|c|}
\hline Field No. ${ }^{3}$. & $\begin{array}{r}\mathrm{K} \lg 24 \\
6 \mathrm{~B}-499\end{array}$ & $\begin{array}{l}\text { Klp } 14 \\
7 B-258\end{array}$ & $\begin{array}{c}\text { Klp } 24 \\
6 W-501\end{array}$ & $\underset{6 W-500}{\mathrm{Klq}^{24}}$ & $\underset{7 W-107}{K l q}$ & $\begin{array}{l}\text { Kla } 14 \\
7 \text { B-260 }\end{array}$ & $\underset{7 \mathrm{~W}-121}{\operatorname{R}}$ \\
\hline Lab. No.. & 150049 & 152010 & 150053 & 150052 & 151986 & 152012 & 152009 \\
\hline $\begin{array}{l}\mathrm{SiO} \\
\mathrm{Al}_{2} \mathrm{O}_{32} \\
\mathrm{Fe}_{2} \mathrm{O}_{32} \\
\mathrm{FeO} \mathrm{MgO} \\
\mathrm{CaO} \\
\mathrm{Na}_{2} \mathrm{O}_{2} \\
\mathrm{~K}_{2} \mathrm{O}_{2} \\
\mathrm{TiO}_{2} \\
\mathrm{P}_{2} \mathrm{O}_{5} \\
\mathrm{MnO}_{2} \\
\mathrm{H}_{2} \mathrm{O}_{2} \\
\mathrm{CO}_{2}\end{array}$ & $\begin{array}{l}64.2 \\
15.4 \\
1.4 \\
3.7 \\
2.0 \\
4.6 \\
2.4 \\
3.3 \\
.71 \\
.19 \\
.10 \\
1.3 \\
.46\end{array}$ & $\begin{array}{l}69.6 \\
14.3 \\
1.6 \\
1.8 \\
.88 \\
2.9 \\
3.3 \\
3.5 \\
.56 \\
.32 \\
.10 \\
.75 \\
.13\end{array}$ & $\begin{array}{l}73.3 \\
14.5 \\
.9 \\
.84 \\
.54 \\
1.4 \\
3.2 \\
4.7 \\
.24 \\
.05 \\
.06 \\
.65 \\
<.05\end{array}$ & $\begin{array}{l}76.9 \\
13.5 \\
.24 \\
.27 \\
.03 \\
.39 \\
3.3 \\
4.7 \\
.02 \\
.00 \\
.01 \\
.74 \\
<.05\end{array}$ & $\begin{array}{c}76.4 \\
13.1 \\
1.1 \\
.9 \\
.12 \\
.41 \\
3.4 \\
4.8 \\
.01 \\
.01 \\
.04 \\
.59 \\
<.05\end{array}$ & $\begin{array}{l}70.7 \\
15.5 \\
.5 \\
1.0 \\
.45 \\
1.2 \\
3.1 \\
5.8 \\
.21 \\
.12 \\
.06 \\
.78 \\
<.05\end{array}$ & $\begin{array}{l}72.6 \\
14.5 \\
.8 \\
.69 \\
.33 \\
.92 \\
2.6 \\
6.1 \\
.24 \\
.06 \\
.08 \\
.66 \\
<.05\end{array}$ \\
\hline Sum & 99.76 & 95.74 & 100.43 & 100.15 & 100.93 & 99.47 & 99.63 \\
\hline $\begin{array}{l}\text { Quartz } \\
\text { Orthoclase } \\
\text { Albite } \\
\text { Anorthite... } \\
\text { Corundum }\end{array}$ & $\begin{array}{l}23.30 \\
20.00 \\
21.00 \\
22.00\end{array}$ & $\begin{array}{l}30.50 \\
20.80 \\
28.40 \\
13.40\end{array}$ & $\begin{array}{r}33.70 \\
27.80 \\
27.30 \\
3.30 \\
1.50\end{array}$ & $\begin{array}{r}40.00 \\
28.40 \\
28.40 \\
.02 \\
2.40\end{array}$ & $\begin{array}{r}35.90 \\
29.26 \\
29.72 \\
2.04 \\
1.57\end{array}$ & $\begin{array}{r}23.85 \\
36.84 \\
27.55 \\
6.14 \\
2.14\end{array}$ & $\begin{array}{r}32.38 \\
36.20 \\
22.08 \\
4.80 \\
-.--\end{array}$ \\
\hline Diopside. & .30 & & & & .31 & & $-2-20-1$ \\
\hline $\begin{array}{l}\text { Hypersthene. } \\
\text { Magnetite. }\end{array}$ & $\begin{array}{l}9.50 \\
2.10\end{array}$ & 3. 22 & $\begin{array}{l}2.60 \\
1.40\end{array}$ & .37 & 40 & $\begin{array}{r}2.39 \\
.73\end{array}$ & $\begin{array}{r}.93 \\
1.16\end{array}$ \\
\hline Apatite & .30 & .34 & 1.30 & & $\cdots$ & 31 & -36 \\
\hline Hematite. & & & & & .84 & & \\
\hline Sum .... & 99.90 & 100.00 & 99.40 & 99.83 & 100.04 & 99.95 & 98.01 \\
\hline
\end{tabular}

1 Analysts: Paul L. D. Elmore, Samuel D. Botts, and Marvin D. Mack, U.S. Geol. Survey.

2 Analysts: Paul L. D. Elmore and Samuel D. Botts, U.S. Geol. Survey.

3 Sample locations are shown in pl. 1.

6B-499, sec. 22 , T. 27 N., R. 38 E.

7B-258, sec. 17, T. 27 N., R. 37 E.

$6 \mathrm{~W}-501$, sec. 9 , T. 28 N., R. $38 \mathrm{E}$.

$6 \mathrm{~W}-500$, sec. 23, T. 29 N., R. $37 \mathrm{E}$.

$7 \mathrm{~W}-107$, sec. 35, T. 29 N., R. $37 \mathrm{E}$.

7B-260, sec. 9, T. 27 N., R. 37 E.

7 W-121, sec. 32 , T. 28 N., R. 37 E.

4 6B-499: granodiorite.

7B-258, 6W-501: porphyritic quartz monzonite.

$6 \mathrm{~W}-500,7 \mathrm{~W}-107$ : equigranular quartz monzonite.

7B-260: alaskite.

$7 \mathrm{~W}-121$ : fne-grained equigranular quartz monzonite.

\section{PORPHYRITIC QUARTZ MONZONITE}

Porphyritic quartz monzonite is the most abundant intrusive rock in the Turtle Lake quadrangle. It underlies an area of about 35 square miles in the southwest, central and northeast parts. The porphyritic quartz monzonite has a gradational contact with the equigranular quartz monzonite of the Loon Lake granite south of the Spokane River and has a sharp contact with the granodiorite. Its northwest boundary is a sharp intrusive contact with the Togo phyllite; elsewhere its boundary is formed by a cover of younger rocks. The quartz monzonite is cut by a few widely scattered dikes of alaskite and pegmatite.

The rock is massive, coarse grained, pinkish to light yellowish gray and contains abundant phenocrysts. It weathers to light gray, but disintegrates rapidly at the surface, and is generally covered by a 
thin mantle of mixed gruṣ and soil that characteristically contains abundant large fragments of potassium feldspar.

The porphyritic quartz monzonite typically contains 35 to 40 percent quartz, 25 to 35 percent potassium feldspar, 25 to 35 percent plagioclase $\left(\mathrm{An}_{10-15}\right), 3$ to 5 percent biotite, and less than 1 percent accessory minerals including apatite, magnetite, sphene, zircon, and muscovite. Table 1 includes norms and chemical analyses of the rock.

Potassium feldspar makes up most of the phenocrysts, but plagioclase and quartz phenocrysts are also present in a few places. The phenocrysts are from 15 to $55 \mathrm{~mm}$ long and are surrounded by a groundmass containing grains from 4 to $6 \mathrm{~mm}$ in diameter. Within a few feet of intrusive contacts the rock commonly is nonporphyritic and locally finer grained.

In places much of the biotite is altered to chlorite. Plagioclase typically is slightly to considerably sericitized. Myrmekitic intergrowths of quartz and plagioclase are common. Inclusions of older rocks are extremely sparse except in a small area in the SW $1 / 4$ sec. 28 , T. 28 N., R. 38 E., where the porphyry contains numerous mafic-rich inclusions 1 inch to 3 inches in diameter.

One small area northeast of Lilienthal Mountain in sec. 18, T. 28 N., R. $37 \mathrm{E}$., is underlain by porphyritic quartz monzonite that contains phenocrysts of salmon-pink microcline. This rock also originally contained from 10 to 12 percent biotite, which is now entirely altered to chlorite. Sphene makes up about 1 percent of the rock.

\section{EQUIGRANULAR QUARTZ MONZONTTE}

Three relatively large bodies and several scattered, small bodies of equigranular quartz monzonite were mapped. One irregular body underlies about 7 square miles south of the river, in the west-central part of the quadrangle, where it is in gradational contact with the porphyritic quartz monzonite. Two somewhat smaller masses intrude phyllite of the Togo formation along the northern border of the map. The rocks are finer grained near their contacts with the phyllite, and the contacts where exposed are sharp, with no apparent difference in the composition of the quartz monzonite at the contact. No inclusions of older rocks were seen. The equigranular quartz monzonite is light yellowish gray and coarse grained. It is typically massive and poorly jointed. It disintegrates rapidly and forms few outcrops. The rock is cut by at least six small, generally east-striking, pyrite-bearing quartz veins.

The equigranular quartz monzonite contains 35 to 40 percent quartz, 28 to 31 percent potassium feldspar, 28 to 30 percent plagioclase $\left(\mathrm{An}_{10}\right)$ and 1 to 5 percent biotite. Apatite, magnetite, muscovite, and sphene 
are present locally as sparse accessories. The quartz monzonite is typically coarse grained; grain size ranges from 3 to $8 \mathrm{~mm}$. Much of the potassium feldspar is perthitic, and has grid-twinning. Most of the plagioclase is sericitized. Norms and chemical analyses of the equigranular quartz monzonite are shown in table 1.

\section{FINE-GRAINED EQUIGRANULAR QUARTZ MONZONITE}

Fine-grained equigranular quartz monzonite underlies an area of about $1 \frac{11}{2}$ square miles in parts of secs. 30,31 , and 32 , T. 28 N., R. 37 E., and secs. 4, 5, and 6, T. 27 N., R. 37 E., south of the Spokane River. A similar, smaller body is in secs. 35 and 36, T. 28 N., R. 36 E. The rock in the larger body has a gradational contact with other rocks of the Loon Lake granite except along the northeastern side, where the contact is covered by Pleistocene sediments. The rock is light gray to yellowish gray, and fine grained. It forms extensive outcrops on Pitney Butte and the hill to the west. Most outcrops are cut by widely spaced, eastward-striking joints.

The fine-grained quartz monzonite contains about 30 percent quartz. 35 percent potassium feldspar, 29 percent plagioclase $\left(A n_{10}\right.$ to $\left.A n_{15}\right)$, 2 percent muscovite, 3 percent biotite, and 0.5 percent magnetite. Traces of apatite are present. The potassium feldspar contains abundant grid twinning. Plagioclase is generally considerably sericitized, and poikilitic intergrowths of quartz in plagioclase are common. Biotite is generally completely or almost completely altered to chlorite. Except for the quartz inclusions in plagioclase, grain size of the rock is remarkably uniform, with more than 95 percent of the individual grains between about $1 / 2 \mathrm{~mm}$ and $2 \mathrm{~mm}$ in diameter. A norm and chemical analyis are given in table 1 .

Contacts between the fine-grained quartz monzonite and the adjacent rocks of the Loon Lake granite are gradational over distances of 50 to 300 feet. They are marked by a gradual increase in grain size, gradual decrease in muscovite content, and in places a somewhat erratic mixture of coarse- to fine-grained rock.

\section{FINE-GRAINED QUARTZ MONZONITE RICH IN MAFIC MINERALS}

A small body of intrusive rock, less than $1 / 4$ square mile in area, crops out along the north side of Blue Creek at the common corner of secs. $22,23,26$ and 27, T. 28 N., R. 37 E. The rock varies considerably in composition, but except for a few, very widely scattered phenocrysts, it is uniformly very fine grained (1 mm or less) and is dominantly a quartz monzonite.

This type of quartz monzonite is light to medium gray, very fine grained, and massive. It is cut by widely spaced, randomly oriented joints. This rock appears more resistant to weathering than the adjacent porphyritic quartz monzonite and is generally fresh and un- 
altered in surface exposures. It grades into porphyritic quartz monzonite over distances of 50 feet to 100 feet.

Modes of two representative specimens are listed below. These illustrate the considerable variation in composition that is characteristic of this rock.

Specimen No.

Quartz

Potassium feldspar

Plagioclase

Biotite

Hornblende

Magnetite

Muscovite

Accessories (apatite, zircon, sphene)
$6 \mathrm{~W}-\mathrm{S17} \mathrm{A}$

27. 4

19. 9

36. 5

13. 1

1. 4

.1

.5

1. 2
$6 W-317 B$

27. 7

33. 8

30. 5

5. 3

.3

.6

1. 8

.1

Potassium feldspar is typically slightly kaolinized. Plagioclase ranges from fresh to highly altered. Sericite, clay minerals, and locally, calcite are the alteration products. Most of the biotite and hornblende are altered to chlorite and magnetite or ilmenite.

\section{ALASKITE, APLITE, AND PEGMATITE}

Many small dikes of aplite, alaskite, and pegmatite cut the granodiorite, porphyritic quartz monzonite, and equigranular quartz monzonite, and a few dikes also cut the pregranitic rocks in the vicinity of Cayuse Mountain and in the northern part of the map area. The dike rocks are generally more resistant to erosion than the enclosing rocks and commonly crop out in low ridges. The rocks weather in angular blocks which form abundant float below outcrops on hillslopes. The contacts with the enclosing rock are sharp in most places, and the rocks show no indication of chilling along the contacts. Generally the rôck in the dikes ranges considerably in grain size and texture. Commonly aplite, alaskite, graphic granite, and pegmatite occur in a single narrow dike. Some pegmatite dikes have cores of milky quartz and a few dikes are almost entirely milky quartz. An example of this is a dike, too small to show on figure 2 , in the $\mathrm{SW} / 4$ sec. 31 , T. $28 \mathrm{~N}$., R. $38 \mathrm{E}$., about 800 feet north of where the gravel road crosses the creek. The dike consists of a milky quartz core about 40 feet in diameter bounded by pegmatite and aplite a few feet thick. The quartz contains a few large potassium feldspar crystals near the pegmatite contact, and sparse, small crystals of pyrite.

The alaskite, aplite, and pegmatite consist of quartz, potassium feldspar and locally albite or oligoclase and small amounts of muscovite, biotite, and magnetite. The composition is quite varied and, as indicated above, some of the dikes are composed almost wholly of quartz. Most of the potassium feldspar is microcline, but some 
crystals do not have grid twinning and are probably orthoclase. Graphic intergrowths of quartz and potassium feldspar are common.

The large dike south of the river near the mouth of Green Canyon in $\mathrm{SW} 1 / 4$ sec. 9 . T. 27 N., R. 37 E., is slightly different from most of the alaskite, aplite, and pegmatite. It has an aplitic texture but contains slightly more biotite and plagioclase than most of the rocks included in this group. However it resembles these rocks more closely chemically and mineralogically than the enclosing quartz monzonite porphyry and thus has been mapped as alaskite.

A chemical analysis and norm of the alaskite from the dike in Green Canyon are given in table 1 .

\section{GRANITE PORPHYRY}

A few small outcrops of granite porphyry extend above the glacial sand and gravel west and southwest of the Big Smoke mine, and three dikes of granite porphyry cut the granodiorite in the vicinity of the Lowley Lease. The rock is light gray to pink, medium to coarse grained, and porphyritic. The rock consists dominantly of quartz and potassium feldspar with a small amount of oligoclase and biotite. Locally the oligoclase makes up 10 to 15 percent of the rock. The only common accessory mineral is magnetite. Quartz forms equant phenocrysts as much as $2 \mathrm{~cm}$ in diameter and equant grains about 2 to $5 \mathrm{~mm}$ in diameter in the groundmass. The boundaries between quartz and potassium feldspar grains are commonly sutured. Potassium feldspar also forms both large phenocrysts and small irregular grains in the groundmass. Some of the larga feldspar phenocrysts are perthitic and some have grid twinning. The phenocrysts of quartz and potassium feldspar in some places make up 50 to 60 percent of the rock and in others only a few percent. The relation of this rock to the aplite and pegmatite is unknown, but the similarity of composition and occurrence suggests a close genetic relationship for these rocks.

\section{LAMPROPHYRE}

Three lamprophyre dikes were mapped in the vicinity of Wellpinit Mountain near the east-central part of the map area-two in granodiorite and one in porphyritic quartz monzonite, Undoubtedly more. dikes are present, but the dike rock normally weathers more rapidly than the enclosing granitic rocks, so that the dikes are concealed under a thick cover of soil and vegetation. The rock is medium to dark greenish gray and consists of phenocrysts of pyroxene (probably augite) and biotite in a groundmass of small laths of plagioclase (probably labradorite), subhedral to euhedral crystals of pyrocene and biotite. Magnetite and apatite are abundant accessory minerals. The rock mapped as lamprophyre at the top of Wellpinit Mountain differs 
considerably from one part of the dike to another. Locally, it contains large phenocrysts of labradorite as well as pyroxene and biotite. The groundmass of some of this rock contains a mineral that appears to be a feldspathoid. It is uniaxial negative, has low positive relief, and its birefringence is about .009. Much of the rock is considerably altered and contains abundant chlorite and calcite.

\section{RHYOLITE}

Two bodies of rhyolite, each about 600 feet in length, are present in the northern part of the quadrangle. In the west-central part of sec. 26 , T. 29 N., R. 37 E., rhyolite has intruded Togo phyllite; in the center of sec. 27 , T. 29 N., R. 37 E., rhyolite intruded Edna dolomite. Neither intrusive body crops out; both are mapped entirely from float.

The rhyolite is a white to very light yellowish gray rock that contains gray euhedral quartz phenocrysts 1 to $2 \mathrm{~mm}$ in diameter in an aphanitic groundmass. Under the microscope, euhedral to subhedral feldspar phenocrysts about $1 / 2 \mathrm{~mm}$ in length can be seen; the feldspar is now completely kaolinized. Anhedral muscovite crystals are also present. Most of the rock is made up of a very finely crystalline intergrowth of quartz and altered feldspar. Quartz appears to make up more than 75 percent of the groundmass.

The rhyolite is similar in composition to some of the alaskite dikes found in the Loon Lake granite, and like the granite rocks, the rhyolite has undergone no regional metamorphism. These similarities between the rhyolite and the granitic rocks led Campbell and Loofbourow (written communication, 1957) to state that the two rocks are probably related in age and origin. In this view, we concur.

TABLE 2.-Lead-alpha age determinations of zircon from the Loon Lake granite

\begin{tabular}{|c|c|c|c|c|}
\hline $\begin{array}{l}\text { Field No. } \\
\text { (see Pl. 1) }\end{array}$ & Rock type & $\alpha / \mathrm{mg}-\mathrm{hr}$ & $\mathrm{Pb}(\mathrm{ppm})$ & $\begin{array}{l}\text { Calculated } \\
\text { age } 1 \text { (in } \\
\text { millions of } \\
\text { years) }\end{array}$ \\
\hline $6 B 499$ & Granodiorite & 453 & $2(18.5,17.0)^{17.7}$ & $100 \pm 10$ \\
\hline $8 \mathrm{~W} 1 \ldots \ldots \ldots$ & Granodiorite... & 389 & 15 & $95 \pm 10$ \\
\hline $8 \mathrm{~W} 2$ & Granodiorite. & 392 & 16.5 & $105 \pm 10$ \\
\hline $6 \mathrm{~W} 501$ & Porphyritic quartz monzonite... & 1097 & $\begin{array}{r}32.3 \\
32.35\end{array}$ & $75 \pm 10$ \\
\hline $8 \mathrm{~W} 3$ & $\begin{array}{l}\text { Porphyritic quartz monzonite } \\
\text { Porphyritic quartz monzonite }\end{array}$ & $\begin{array}{l}1089 \\
1365\end{array}$ & $\begin{array}{r}346 \\
16.3 \\
3(16,16.5)\end{array}$ & $\begin{array}{r}105 \pm 10 \\
95 \pm 10\end{array}$ \\
\hline
\end{tabular}

1 From the following equation: $t=\frac{C \mathrm{~Pb}}{\alpha}$
$t=$ calculated age in millions of years

$C=$ a constant, 2485 , based upon assumed $\mathrm{Th} / \mathrm{U}$ ratio of 1.

$\mathrm{Pb}=$ lead, in parts per million

$\alpha=$ alpha coun ts per milligram per hour

Errors yuoted here are those due only to uncertainties in analytical techniques.

2 Lead determinations by H. J. Rose, Jr., and H. W. Worthing.

3 Lead determinations by Nola B. Sheffey. 
AGE

The Loon Lake granite is one of many similar large intrusive bodies in northeastern Washington none of which previously had been dated precisely. These bodies cut late Paleozoic rocks and are overlain by rocks of Tertiary age. Weaver (1920, p. 87) considered the Loon Lake granite to be of Mesozoic age.

Lead-alpha ages of zircon from the porphyritic quartz monzonite and the granodiorite, as calculated by T. W. Stern, U.S. Geological Survey (table 2), indicate that the Loon Lake granite is Cretaceous in age.

\section{TERTIARY ROCKS}

GEROME ANDESITE

The Gerome andesite was first described by. Weaver (1920), who stated that it consists of flows, breccias, tuffs, and interbedded sandstones and carbonaceous beds that unconformably overlie the granitic and older rocks.

In the Turtle Lake quadrangle, the Gerome andesite occurs only in a fairly well defined belt a few miles wide along the Spokane River and extending through Enterprise Valley, a northwest-trending extension of the Spokane River valley. We mapped two units in the formation: flow rocks and pyroclastic rocks that locally contain intercalated sandstone, conglomerate, and carbonaceous shale beds. Where differentiation was impractical at the scale of mapping, the rocks are grouped together and shown as Gerome undivided (pl. 1). Intrusive rocks that form the many dikes shown on plate 1 along the belt mentioned above are considered intrusive equivalents of the Gerome andesite.

\section{FLOW ROCKS}

Most of the Gerome andesite in the map area is flow rock. The flows form prominent, extensive outcrops in the south-central part of the quadrangle and along the north side of the Spokane River from the mouth of Blue Creek northwest to Enterprise Valley (fig. 4). The flows are dark gray, and weather to a reddish brown, purplish or greenish gray. The rock is cut by a multitude of closely spaced, irregular joints that result in a very rough, irregular surface on most outcrops.

The thickness of individual flows could not be determined; flow tops and bottoms were generally recognizable only where they were in contact with other rock types. In a few places, individual flows appeared to be 75 feet to 100 feet thick. Weaver $(1920$, p. 99) states that the total thickness of flows and interbedded sedimentary and pyroclastic rocks is at least 700 feet. Estimates of the apparent thickness along the east side of Enterprise Valley suggest that there the formation may be greater than 1,500 feet thick. 


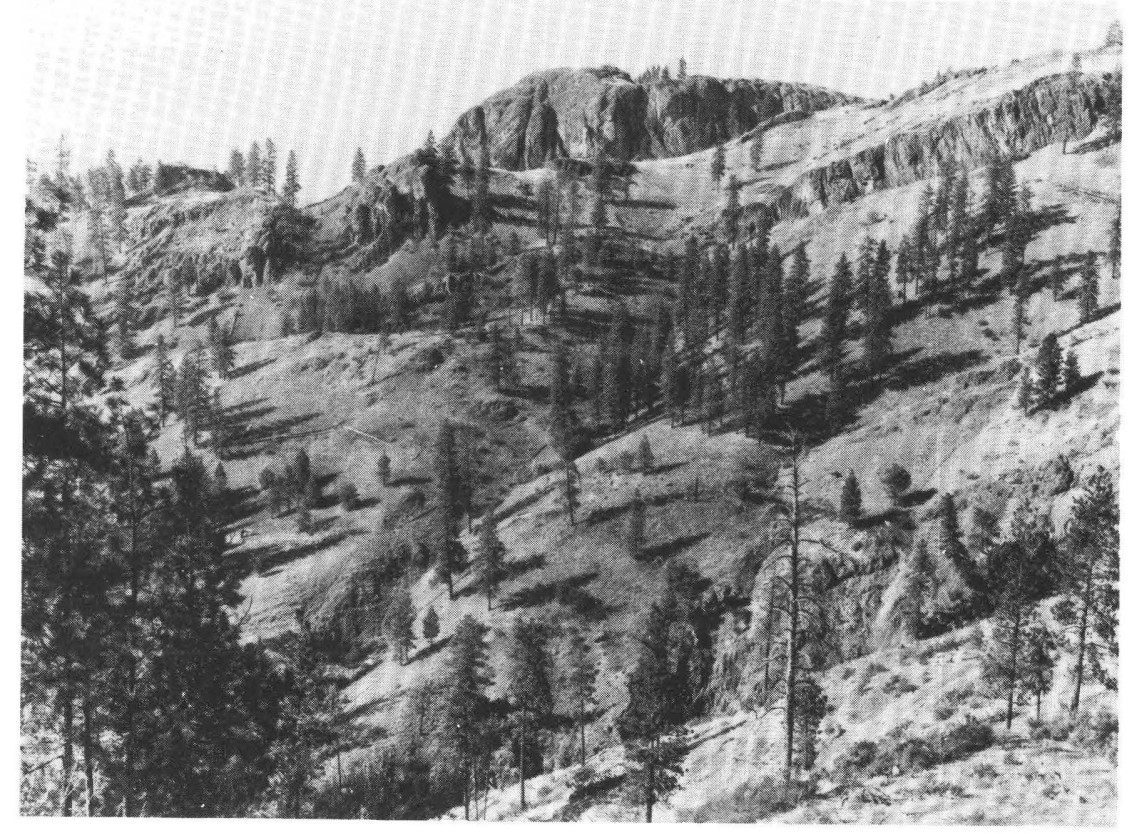

FIGURE 4.-Flows of Gerome andesite near the mouth of Sand Creek, Spokane Indian Reservation.

The flows are typically porphyritic, with lustrous black hornblende or augite phenocrysts (or rarely both) 2 to $10 \mathrm{~mm}$ long, scattered through a dense, medium-gray to dark-gray groundmass. In a few places, plagioclase phenocrysts are also present. The groundmass is a mixture of randomly oriented plagioclase laths $\left(\mathrm{An}_{40}\right.$ to $\left.\mathrm{An}_{45}\right)$, biotite, hornblende, and augite crystals, in an aphanitic to glassy matrix.

The plagioclase is generally fresh, but in places it is slightly sericitized. Much of the hornblende is altered to chlorite, with rims of magnetite. Augite is present in some of the rock and is unaltered. Hypersthene occurs in the flow rocks near the mouth of Harker Canyon. Quartz is present locally in trace amounts. The feldspar laths and hornblende needles are randomly oriented except locally where they show subparallel alinement. Analyses and calculated norms of samples $6 \mathrm{~W}-502 \mathrm{~A}$ and $6 \mathrm{~W}-502 \mathrm{~B}$, shown in table 3 , indicate that the flow rocks are rhyodacite.

\section{PYROCLASTIC AND SEDIMENTARY ROCKS}

Tuff, lapilli tuff, tuff-breccia, and intercalated tuffaceous sandstone, arkose, conglomerate, and impure carbonaceous shale beds are interlayered with the flow rocks in several places. Excellent exposures of unbedded crystal tuff are present along the north side of McCoy Lake and in places along Orazada Creek. Tuffaceous sandstone, 
TABLE 3.-Chemical analyses and calculated norms of Gerome andesite

\begin{tabular}{|c|c|c|c|c|c|}
\hline Field No. ${ }^{3}$ & $7 \mathrm{~B}-25924$ & $6 \mathrm{~B}-50014$ & $7 \mathrm{~W}-120^{24}$ & $6 \mathrm{~W}-502 \mathrm{~A} \quad 1 \quad 4$ & $6 \mathrm{~W}-502 \mathrm{~B}^{14}$ \\
\hline Lab. No & 152011 & 150050 & 152008 & 150054 & 150055 \\
\hline $\begin{array}{l}\mathrm{SiO}_{2} \\
\mathrm{Al}_{2} \mathrm{O}_{3} \\
\mathrm{Fe}_{2} \mathrm{O}_{3} \\
\mathrm{FeO} \mathrm{O} \\
\mathrm{MgO} \mathrm{O} \\
\mathrm{CaO} \\
\mathrm{Na}_{2} \mathrm{O}_{2} \\
\mathrm{~K}_{2} \mathrm{O}_{2} \\
\mathrm{TiO}_{2} \mathrm{O}_{2} \\
\mathrm{P}_{2} \mathrm{O}_{5} \\
\mathrm{MnO} \mathrm{O} \\
\mathrm{H}_{2} \mathrm{O}_{2} \\
\mathrm{CO}_{2}\end{array}$ & $\begin{array}{l}63.2 \\
13.9 \\
2.2 \\
3.1 \\
3.2 \\
4.0 \\
2.8 \\
4.2 \\
.78 \\
.42 \\
.12 \\
2.0 \\
.05\end{array}$ & $\begin{array}{r}64.7 \\
14.6 \\
1.8 \\
2.2 \\
2.3 \\
2.9 \\
3.3 \\
4.3 \\
.55 \\
.20 \\
.07 \\
2.0 \\
1.1\end{array}$ & $\begin{array}{l}61.6 \\
14.5 \\
2.7 \\
1.5 \\
2.3 \\
4.8 \\
2.1 \\
2.0 \\
.64 \\
.22 \\
.08 \\
7.8 \\
.05\end{array}$ & $\begin{array}{c}61.0 \\
16.5 \\
2.4 \\
3.0 \\
2.8 \\
5.4 \\
3.7 \\
1.7 \\
.81 \\
.31 \\
.10 \\
2.0 \\
.06\end{array}$ & $\begin{array}{c}61.0 \\
16.6 \\
4.6 \\
.88 \\
2.3 \\
4.6 \\
3.1 \\
3.3 \\
.82 \\
.33 \\
.10 \\
1.8 \\
.05\end{array}$ \\
\hline Sum. & 99.97 & 100.02 & 100.29 & 99.78 & 99.48 \\
\hline $\begin{array}{l}\text { Quartz } \\
\text { Orthoclase } \\
\text { Albite } \\
\text { Anorthite. } \\
\text { Corundum. } \\
\text { Diopside. } \\
\text { Hypersthene } \\
\text { Magnetite } \\
\text { Apatite } \\
\text { Ilmenite } \\
\text { Hematite. }\end{array}$ & $\begin{array}{r}19.30 \\
25.10 \\
23.65 \\
13.65 \\
3.16 \\
9.44 \\
3.25 \\
1.01 \\
1.37\end{array}$ & $\begin{array}{r}20.00 \\
26.10 \\
28.80 \\
12.80 \\
1.13 \\
6.80 \\
2.80 \\
.34 \\
1.20\end{array}$ & 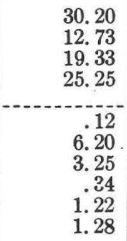 & $\begin{array}{r}18.60 \\
10.00 \\
32.00 \\
24.20 \\
7.93 \\
3.70 \\
.70 \\
1.50\end{array}$ & $\begin{array}{r}18.60 \\
20.00 \\
27.00 \\
21.40 \\
.10 \\
5.80 \\
.90 \\
.67 \\
1.50 \\
4.00\end{array}$ \\
\hline Sum_-_. & 99.93 & 99.97 & 99.92 & 99.53 & 99.97 \\
\hline
\end{tabular}

1 Analysts: Paul L. D. Elmore and Samuel D. Botts, U.S. Geol. Survey.

2 Analysts: Paul L. D. Elmore and Marvin D. Mack, U. S. Geol. Survey.

3 Sample locations are shown on pl. 1.

7B-259, sec. 17,T. 27 N., R. 37 E.

6 B- 500 , sec. 28 , T. 27 N., R. $38 \mathrm{E}$.

$7 \mathrm{~W}-120$, sec. 36 , T. 29 N., R. $36 \mathrm{E}$.

$6 \mathrm{~W}-502 \mathrm{~A}$, sec. 17, T. 28 N., R. $37 \mathrm{E}$.

$6 \mathrm{~W}-502 \mathrm{~B}$, sec. 16, T. 28 N., R. 37 E.

$47 \mathrm{~B}-259.6 \mathrm{~B}-500$ : intrusive rocks equivalent to the Gerome andesite.

$7 \mathrm{~W}-120$ : tuff of the Gerome andesite.

$6 \mathrm{~W}-502 \mathrm{~A}, 6 \mathrm{~W}-502 \mathrm{~B}$ : flow rocks of the Gerome andesite.

arkose, conglomerate, and carbonaceous shale are present at the Northwest Uranium mine, sec. 35, T. 28 N., R. 37 E. Lapilli tuff and tuff-breccia are well exposed on the east wall of Harker Canyon in sec. 1 , T. 26 N., R. 37 E.

The pyroclastic and associated sedimentary rocks weather readily and do not form extensive outcrops. Their color ranges from gray to light tan or nearly white. The tuff generally is not bedded or is very poorly bedded. The sedimentary rocks are well bedded. In many places they dip $20^{\circ}$ to $30^{\circ}$ toward the Spokane River, undoubtedly the result of postdepositional tilting.

The pyroclastic and related rocks exhibit a wide range of textures and compositions. All contain erystals or crystal fragments large enough to be identified under the microscope and, also, all contain a large proportion of volcanic glass and unidentified fine-grained material. Unstratified crystal tuff, typified by the exposures along the north side of McCoy Lake, contains abudant euhedral to subhedral crystals of zoned plagioclase $\left(\mathrm{An}_{35}\right.$ to $\left.\mathrm{An}_{65}\right)$, together with less abundant 
hornblende, augite, biotite, and magnetite. The minerals are surrounded by a groundmass composed mainly of devitrified glass, together with remnants of glass shards in places. A chemical analysis and calculated norm of this rock are shown in table 3 .

Bedded tuff in sec. 7, T. 28 N., R. 37 E., appears to be typical crystal tuff similar in composition to the unstratified tuff at McCoy Lake, but in places draping of shard remnants around some of the crystals suggests a slight degree of welding. The hornblende of the bedded tuff, unlike that in the unstratified tuff near McCoy Lake, is commonly slightly altered.

At the Northwest Uranium mine, some of the rocks are arkosic; other layers contain carbonaceous material in amounts ranging from a trace to 60 percent. Two carbonized tree stumps were exposed in bulldozer trenches, and one layer of tuffaceous sandstone contained well-preserved plant fossils. (See p. 37.)

\section{INTRUSIVE ROCKS}

In the general area where the Gerome andesite is exposed many small dikes cut the Loon Lake granite and the older metamorphic rocks, and a few such dikes cut flow rocks and pyroclastic rocks of the Gerome andesite. Many of the dikes are only a few feet wide and a few tens of feet long, but others are as much as a mile long, and one stock in Harker Canyon has a diameter of about $1 / 3$ mile.

The dike rock is commonly more resistant to weathering than the enclosing rock and in many places forms elongated outcrops. Many of the dikes have a general northwestward trend and dip steeply.

The rock is commonly medium to light gray and has light gray to white phenocrysts of feldspar and lustrous black biotite and greenish hornblende phenocrysts. Chilled margins were observed in some of the dikes. In these dikes the groundmass is dense and black to dark greenish gray at the contact and grades into a medium-gray crystalline groundmass toward the center of the dike. The chilled margin is only a few inches to a few feet wide. A dike with a chilled margin is well exposed in Green Canyon near the northeastern corner of sec. 17, T. 27 N., R. 37 E.

The rock mapped as Gerome andesite undivided east of the mouth of Mill Creek in the southwestern corner of sec. 32, T. 27 N., R. 38 E., appears to grade upward from typical gray, porphyritic intrusive rock at the level of the lake to a black, dense rock, which resembles the flows of the Gerome farther west, at the top of the ridge. This suggests that some of the dikes were feeders for the flows.

The older rocks adjacent to the dikes do not generally appear to have been altered during the intrusion; however, in a few places where the dikes cut the Loon Lake granite most of the joint surfaces 
in the granitic rocks near the dikes are coated with a very thin layer of chlorite. The spatial relationship suggests that the deposition of the chlorite took place during the intrusion of the dikes.

The intrusive rocks are typically porphyritic with zoned, lath-shaped phenocrysts of plagioclase $\left(\mathrm{An}_{40-50}\right)$ commonly as much as $12 \mathrm{~mm}$ in length, biotite and hornblende phenocrysts commonly 5 to $10 \mathrm{~mm}$ long, equant phenocrysts of pyroxene (probably augite), and rarely equant phenocrysts of quartz in a groundmass made up of small laths of plagioclase, grains of biotite and hornblende and probably potassium feldspar and quartz. Magnetite and apatite are common accessory minerals. The plagioclase phenocrysts are generally slightly rounded and are locally embayed by the groundmass. Most are partly sericitized and some are almost entirely replaced by sericite. The biotite is largely unaltered in many sections, but in some it is partly to almost completely altered to chlorite. Hornblende is green, euhedral to subhedral, and locally it is altered to chlorite. The pyroxene is usually in anhedral color'ess grains and is fresh. Some of the sections examined contain secondary calcite in irregular grains.

Chemical analyses and norms of two samples of the intrusive rocks are given in table 3 . These analyses indicate a moderate range in composition of the rocks, particularly in total iron, magnesium and calcium, and both analyses are notably higher in potassium than the flow rocks or tuff of the Gercme andesite.

AGE

The flow rocks, pyroclastic rocks, and associated sedimentary rocks of the Gerome andesite unconformably overlie the Precambrian and Paleozoic metasedimentary rocks, and the Cretaceous Loon Lake granite. They are in turn overlain by the Columbia River basalt of Miocene age. Plant fossils found in tuffaceous sandstones of the Gerome at the Northwest Uranium mine were identified by Roland Brown (written communication, 1956) as Metasequoia occidentalis (Newberry) Chaney (fig. 5) and ?Sequoia affinis Lesquereux, and described as being most probably of Oligocene age. Samples of carbonaceous material, also from sedimentary rock of the Gerome at the Northwest Uranium mine, contain pollen grains identified as Betula, Alnus, cf. Picea, cf. Engelhardtia, cf. Pterocarya, cf. Ulmaceae, cf. Zelkova, and cf. Sequoia (Estella Leopold, written communication, 1956). According to Leopold, the pollen grains represent a postPaleocene, pre-Miocene flora. The Gerome andesite is clearly older than the Columbia River basalt, and the fossil assemblages suggest that the interbedded sedimentary rocks are most probably Oligocene in age. 


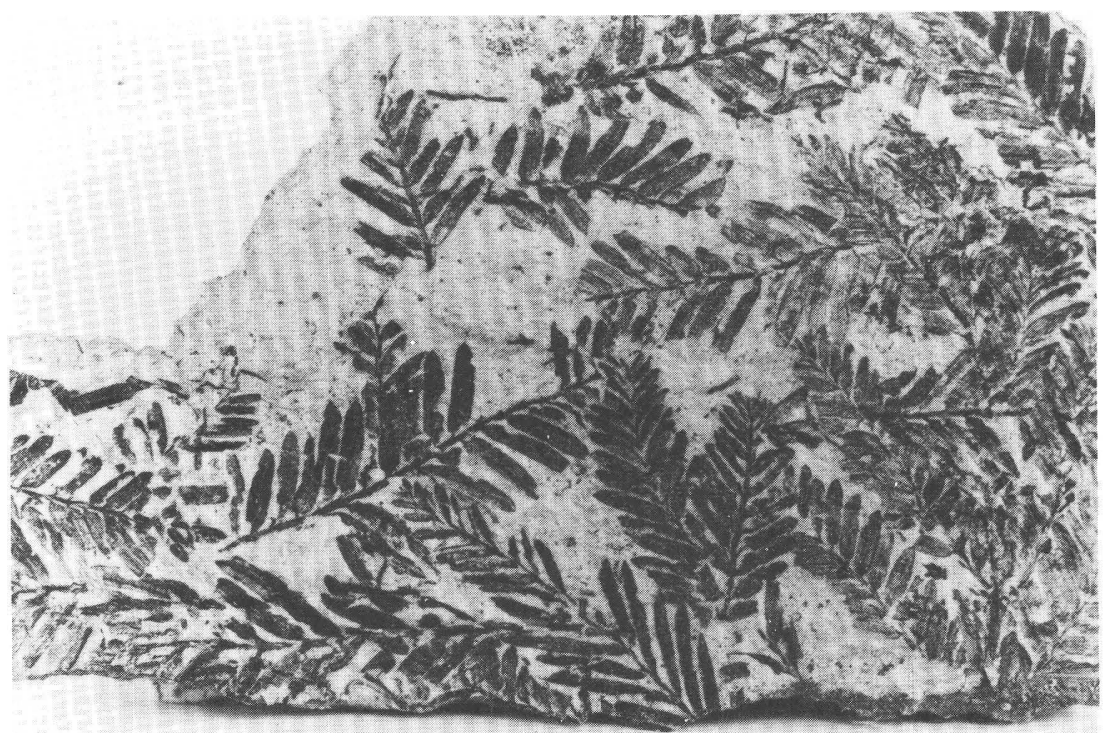

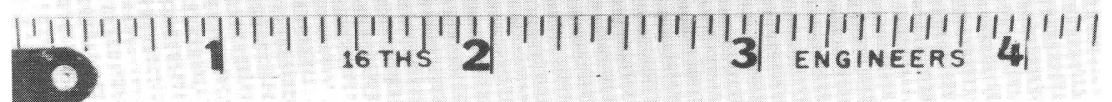

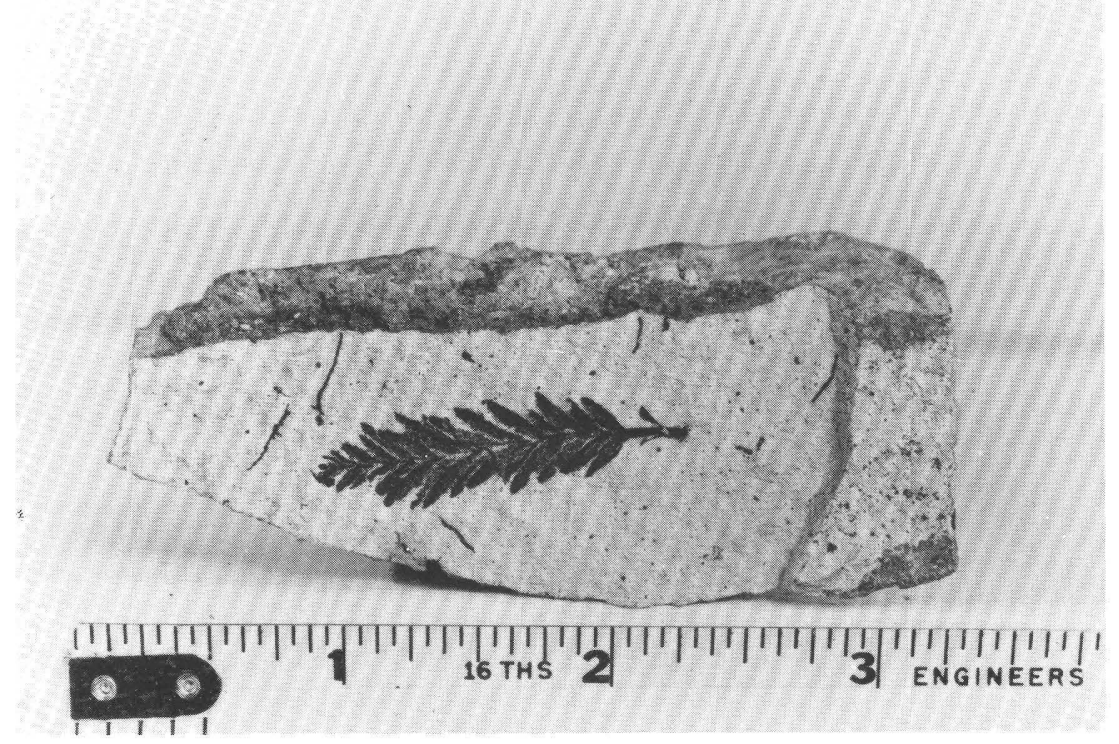

FIGURE 5.-Metasequoia occidentalis (Newberry) Chaney. From tuffaceous sandstones of the Gerome andesite, Northwest U ranium mine. 


\section{COLUMBLA RIVER BASALT}

Much of the southern part of the Turtle Lake quadrangle is underlain by basalt that is part of the great volume of Columbia River basalt in eastern Washington, Oregon, and southern Idaho. I. C. Russell (1893) originally named the basalt Columbia lava and stated (p. 20-21): "The Columbia lava is not one vast flow, but is composed of many separate flows, sometimes separated by land surfaces $* * *$ or sheets of lapilli. The sheets of which it is composed overlap and supplement each other, so as to form one continuous but highly compound system." Later he changed the name of the formation to Columbia River lava (1901, p. 28). Subsequently, other geologists have indicated the formation can be divided into rocks of different ages. G. O. Smith (1901) proposed the name Yakima basalt for the Miocene lavas of eastern Washington, but because of the lack of precise dating in the Turtle Lake quadrangle the formation is given the more general name Columbia River basalt.

\section{DISTRIBUTION AND GENERAL CHARACTER}

The Columbia River basalt flowed out on an area of considerable relief, and the upper flows are much more extensive in the quadrangle than the lower ones, which are exposed in the deeper canyons such as Indian Creek Canyon near the southwestern corner of the quadrangle. In the vicinity of Harker Canyon, the horizontal flows unconformably overlie the Paleozoic(?) metasedimentary rocks. South of Lilienthal Mountain the basalt lies on an erosion surface cut on granodiorite and quartz monzonite of the Loon Lake granite. Locally, the basalt unconformably overlies the Oligocene Gerome andesite.

The Palouse formation overlies the basalt south of the Spokane River, except where the basalt is exposed along valley walls and in late Pleistocene scabland channels. Locally the basalt has also been covered by glacial outwash.

In addition to the large area of basalt in the southern part of the quadrangle, Columbia River basalt occurs east of Turtle Lake in the northeastern part of the quadrangle and as small remnants north of the Spokane River near the center and in the northwestern corner of the map area. The basalt originally covered a much greater part of the quadrangle but much has been removed by erosion.

In the southwestern corner of the quadrangle the formation is at least 900 feet thick, but the base is not exposed, and the total thickness in this area may be considerably greater. Several individual horizontal flows can be recognized along the steep canyon walls in this area, but because of a considerable soil cover, none can be traced very far. The upper surface of the formation is at approximately 2,500 feet elevation and does not vary more than 100 feet from this 
elevation for many miles east, south, and west of the quadrangle except where broad channels have been eroded in the top of the formation.

The rock is commonly vesicular in the top few feet of the flows, and locally pillow structures are developed. Pillow basalt is particularly well exposed in road cuts along Indian Creek road, along State Highway 22 near Egypt Church, and along the county road in NE/4 sec. 10 , T. 26 N., R. 38 E. At the last locality, small, intensely altered fragments of the underlying metasedimentary rocks are included in the weathered rock between the pillows.

The rock is highly jointed, and columnar jointing is moderately well developed in the flows in a few places, but throughout most of the area the the jointing would be better described as irregularly blocky. Individual joint surfaces are commonly curved and discontinuous, and the abundant talus below all outcrops consists of small irregular blocks of basalt.

\section{PETROGRAPHY}

The basalt is dark grayish black and is made up of almost microscopic laths of plagioclase in a dense groundmass. It has intersertal to subophitic textures. Randomly oriented laths of plagioclase are separated by grains of pyroxene, olivine, and magnetite in brown glass. Some of the glass contains variolitic feldspar. The plagioclase is labradorite ranging from $A_{50}$ to $A_{n}$ and averaging about $\mathrm{An}_{60}$. It is fresh, commonly twinned after the albite law, and a few laths are faintly zoned near their margins. Most of the pyroxene appears to be pigeonite $\left(2 \mathrm{~V}_{\mathrm{Z}} 10^{\circ}-30^{\circ}\right)$. It occurs as granules and subhedral crystals that average about $0.2 \mathrm{~mm}$ in length. The olivine is remarkably unaltered-only a few grains are very slightly altered along their edges to a yellowish-brown isotropic material. The olivine occurs as round grains and subhedral crystals, which are as much as $0.7 \mathrm{~mm}$ in diameter and average about $0.2 \mathrm{~mm}$. The olivine makes up about 1 percent to almost 10 percent of the rock in the sections examined. Magnetite is abundant and occurs as discrete granules and in rods. The high titanium content indicated in the two chemical analyses (table 4) indicates that ilmenite is present also. The amount of glass is variable from one thin section to another.

Aaron C. Waters (1961) states that the two samples cited in table 4 are texturally and mineralogically very close to flow rocks of the Yakima-Columbia Gorge region. These rocks, which he refers to as "Late Yakima (Early Ellensburg) flows," contain considerably more olivine and feldspar than the "normal" Yakima basalt. 
TABLE 4.-Chemical analyses, in weight percent, of the Columbia River basalt [Analysts: P. L. D. Elmore, S. D. Botts, and M. D. Mack, U.S. Geol. Survey]

\begin{tabular}{|c|c|c|}
\hline No. ${ }^{1}$ & $7 \mathrm{~B} 261$ & $6 \mathrm{~B} 501$ \\
\hline Lab. No & 152013 & 150051 \\
\hline 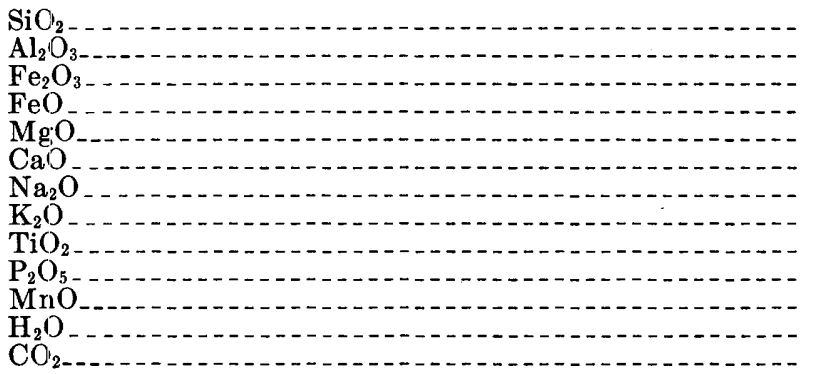 & $\begin{array}{r}\text { 50. } 0 \\
\text { 14. } 1 \\
2.1 \\
\text { 11. } 6 \\
4.3 \\
8.1 \\
2.8 \\
1.4 \\
3.2 \\
.79 \\
.24 \\
\text { 1. } 8 \\
<.05\end{array}$ & $\begin{array}{r}\text { 49. } 6 \\
12.8 \\
1.9 \\
13.2 \\
4.4 \\
8.4 \\
2.5 \\
1.3 \\
\text { 3. } 4 \\
.81 \\
.27 \\
1.0 \\
.31\end{array}$ \\
\hline Sum & 100.48 & 99.89 \\
\hline
\end{tabular}

1 Sample locations shown on pl. 1 .

7B261, from a quarry north of State Highway 22 near the eastern boundary of sec. 19, T. 27 N., R. $37 \mathrm{E}$.

6B501, from small knob in SE1/4 sec. 34, T. 28 N., R. 37 E.

\section{AGE}

The Columbia River basalt elsewhere includes rocks from Miocene to Pliocene (?) in age. East of the quadrangle near Spokane, Pardee and Bryan (1926) indicate that the Columbia River basalt overlies the Latah formation which contains flora of Middle or Late Miocene age. Kirkham and Johnson (1929) found fine-grained sediments containing Latah flora over a much wider area than Pardee and Bryan had studied, and these sediments were actually interbedded with the basalt flows at several different horizons. Therefore they concluded the Latah formation is a series interbedded with the Columbia River basalt, rather than underlying it.

Although no direct correlation of the basalt in the Turtle Lake quadrangle and the basalt in the vicinity of Spokane can be made on the basis of existing information, the continuity of the basalt outcrops, the horizontal attitude of the flows with no indication of folding or major faulting in the basalt, and the similarity of elevation of the upper surface of the basalt in the area between Spokane and the Turtle Lake quadrangle, suggest that the basalts are of the same age. An age of Miocene is assigned to the Columbia River besalt in the Turtle Lake quadrangle.

\section{QUATERNARY DEPOSITS}

\section{GENERAL FEATURES}

The Quaternary deposits in the Turtle Lake quadrangle consist of (1) the Palouse formation, (2) glacial deposits including glacio- 
fluvial and glaciolacustrine deposits and moraine, (3) alluvium; and (4) landslide deposits. To enable the reader to follow the detailed discussion of the Quaternary deposits, a general interpretation of the relations between them is presented first.

The Palouse formation consists chiefly of loess deposited during the Pleistocene before the last glacial epoch. No evidence of glaciation prior to the deposition of the Palouse was observed in the Turtle Lake quadrangle; this of course does not mean that such glaciation might not have occurred, but simply that if it did, no record remains in the area. Also no till nor glaciofluvial deposits were observed similar to those southeast of the quadrangle described by Flint (1937, p. 216-217) as underlain by "Palouse soil" and overlain by a "superficial loess." Bretz (1923) and Bryan (1927) describe some of the same localities discussed by Flint and believe the till is older than the latest glaciation in the area. Flint disagrees and states (1937, p. 222):

It is possible that the drift on the plateau dates from a glaciation earlier than the one responsible for the valley fill. [The valley fill refers to the stratified fill in the deep valleys north of the Columbia plateau.] It is even possible that all three bodies [two different tills on the plateau and the valley fill] are of different ages. Such difference, however, is not demonstrated by the facts now known, which point to a single common age for them all-namely, Wisconsin.

Flint includes two small scale maps (1937, pl. 5 and fig. 1) showing that ice covered most of the Turtle Lake quadrangle (fig. 6). Of course Flint's maps are considerably generalized because of the large area of his study, which includes the study of glaciation of most of northeastern Washington from Chelan on the west to the WashingtonIdaho boundary on the east. Flint also states that the drift border is distinctly lobate in detail; the present study indicates that in the vicinity of the Turtle Lake quadrangle it is more lobate than he indicated.

As evidence of ice having covered the area, Flint uses two criteria: till and erratic stones, and ice-modified topography. The explanation given by Flint for his belief that the topography developed on the Palouse indicated modification by ice seems to be inadequate to prove, or even strongly suggest, glaciation. Flint states (1937, p. 211),

South of the glaciated region, the topography of the "Palouse Soil" is very regular, with a systematic drainage pattern. Individual hills have steep slopes, ranging up to 20 degrees. But in the Creston-Spokane district, the regularity and system are modified. Slopes are reduced so that few are as steep as $\mathbf{1 0}$ degrees, relief is reduced, minor interfluves become irregular, and divides between two opposing stream heads are locally cut through. The topography is not quite the swell-and-swale of typical ground moraine, but it is clearly abnormal. It lacks the lateral scarps and the continuity of slope that characterize stream- 


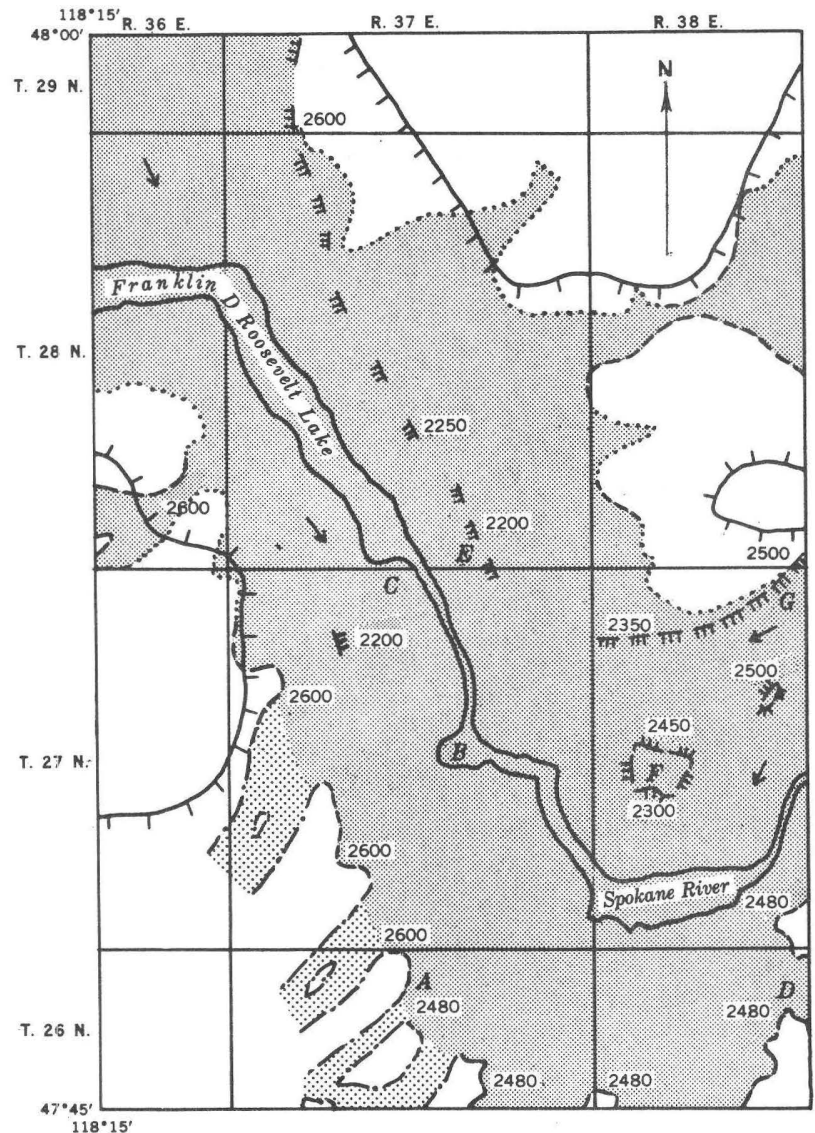

EXPLANATION

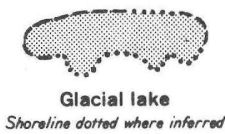

$\pi m \pi m \pi m \pi$

Upper limit of ice

Hechures on ice side

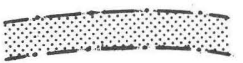

Meltwater channels cut through Palouse formation exposing bedrock

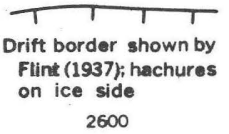

Elevation above sea level

A

Locality referred to in text

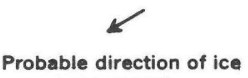

movement

FigurE 6.-Sketch map of the Turtle Lake quadrangle showing Pleistocene lake, upper limit of ice erosion and melt-water channels

erosional topography in the "Palouse soil" beyond the glaciated region, and cannot, therefore, be a product of stream erosion.

These modefications become more apparent northward, vertically downward, and immediately adjacent to the larger north-south streamways on the plateau. Most important of all is that the region in which the surface is thus modified corresponds closely with the region in which till and erratic stones are present. The facts already cited point to the conclusion that the topographic modification is the result of direct glacial erosion of the preglacially dissected "Palouse soil."

It seems improbable that glaciers could have moved over the loessic hills in the southern part of the Turtle Lake quadrangle, which correspond in form with Flint's "abnormal topography," and left no gravel whatsoever on the Palouse. No gravel was observed mixed with the loess except on the north- and northeast-facing slopes which drain into the Spokane River. This gravel was apparently deposited along shores of ice-dammed lakes in the Spokane River valley. Flint 
(1937, p. 214) points out that loess has accumulated to a depth of 9 feet over glacial deposits at one locality southeast of Spokane, but states that elsewhere the capping of loess rarely exceeds 3 feet. No evidence of such accumulation of late- and post-glacial loess was found in the Turtle Lake quadrangle. The soil cover in the scabland channels formed by glacial melt water $n$ the southern part of the quadrangle is rarely more than a few inches thick. Locally thicker soil in the channels can be accounted for by wash from the low hills of Palouse adjacent to the channels. Possibly conditions were more favorable for deposition of postglacial loess on the hills of Palouse than in the channels, but even if as much as 3 feet had accumulated over till, some pebbles or boulders certainly would be exposed by frost-heaving or erosion in stream valleys cut in the Palouse. Some of the Palouse is deepy gullied by runoff during severe thundershowers, but no gravel was observed in these gullies. Another feature that suggests that very little loess has accumlated in late- and post-glacial time is the presence of the pebbles, cobbles, and boulders, as mentioned earlier, mixed with the Palouse on the north- and northeast-draining slopes. These pebbles, cobbles, and boulders, now exposed probably would have been covered by about the same thickness of loess as any till that might have been deposited over the Palouse on the plateau. No evidence of any such cover was observed. Had it been present, certainly it would not have been removed only in the areas covered by the lake. Thus the "abnormal topography" mentioned by Flint as evidence of glaciation must have some origin other than ice modification.

Glacial scouring, which removed all the weathered material and exposed fresh granitic rock, indicates that ice extended into the quadrangle from the northwest and east (fig. 6). A lake, possibly more than one, occupied the Spokane River valley and spilled out through channels to the southwest. Though the detailed history of the lake stage in unknown certain observations can be made. The lake apparently did not remain long at its maximum level because no evidence of strand lines were observed; however, ice-rafted boulders, cobbles, and pebbles indicate the presence of at least one lake. Northwest of point A (fig. 6) the ice-rafted boulders extend up to an elevation of 2,600 feet; east of this point they extend up to only 2,480 feet.

After the retreat of the glaciers that formed the lake, the Spokane River was again dammed but at a much lower level. The extenisive stratified sand, silt, and gravel deposits in the Spokane River valley, which extend many miles east and west of the quadrangle, were deposited in this lake. Flint (1936) traces these deposits as far west as Grand Coulee and states that they are graded to a rock threshold in Grand Coulee. 
After the removal of the last ice dam, the Spokane River cut broad terraces at several levels in the valley fill and removed much of it. The surfacès of some of the terraces have been modified by eolian deposits. Several landslides have occurred in the fill since the construction of Grand Coulee dam forming Franklin D. Roosevelt Lake.

\section{PALOUSE FORMATION}

The Palouse formation, which overlies much of the Columbia plateau in eastern Washington, was named by Treasher (1925) but was first described much earlier by Russell (1897). Calkins (1905, p. 44-49) appears to have been the first to suggest that the Palouse was deposited by wind and not derived by weathering of the underlying basalt. He also held that the formation was once a continuous layer and has since been dissected. Treasher believed that the formation was deposited by glacial melt water during the retreat of the glaciers from eastern Washington, but subsequent work has indicated that although some water-laid deposits are present locally, almost all of the deposit is wind-laid. For further discussion of the origin, source, and age of the Palouse formation, the reader is referred to reports by Bryan (1927), Krynine (1937), Culver (1937), Rieger, ${ }^{1}$ and McCreery. ${ }^{2}$

In the Turtle Lake quadrangle the Palouse is restricted to the relatively flat surface of the Columbia plateau where the plateau has not been dissected by late Pleistocene and Recent erosion. The formation almost certainly covered most of the area south of the Spokane River, but much of the original deposit was removed by glacial melt.water during the time that glacially dammed lakes in the Spokane River valley drained southwestward.

Exact thickness of the Palouse in the area is unknown; probably the formation is generally thinner than the 100 to 150 feet reported by Bryan $(1927$, p. 21$)$ in southeastern Washington. In road cuts near Egypt in $\mathrm{NE}_{1 / 4}^{1}$ sec. 24, sec. 12, and in $\mathrm{SW} / 4$ sec. 1, T. $27 \mathrm{~N}$., R. $36 \mathrm{E}$., the Palouse is only 2 to 5 feet thick. In each of these road cuts the Palouse rests on hills of quartz monzonite that protrude through the basalt. South of the Turtle Lake quadrangle, the Palouse is also much thinner on, or absent from, hills of older rocks that extend above the basalt. Whether this indicates that the loess was not deposited on these higher hills or was deposited and then removed by erosion is not known. In the Turtle Lake quadrangle where the Palouse overlies the apparently nearly flat surface of the basalt in secs. 1, 2, and 13, T. 26 N., R. $36 \mathrm{E}$., in the southwestern

\footnotetext{
${ }_{1}$ Rieger, Samuel, Development of the $\mathrm{A}_{2}$ horizon in soils of the Palouse area: Washington State Univ. Pullman, Wash., Ph. D. thesis in agronomy, 1952.

${ }^{2}$ McCreery, Robert A., Mineralogy of Palouse and related series: Washington State Univ., Pullman, Wash., Ph. D. thesis in agronomy, 1954.
} 
corner of the map area, it forms hills that are about 100 feet above the basalt surface. Thus, it appears that the Palouse thins rapidly toward the north and east where the hills formed by rocks older than the basalt rise above the basalt surface. If the Palouse was deposited in the Spokane River valley, it has been removed later by erosion. No Palouse was recognized north of the Spokane River in the nonglaciated areas.

The Palouse in the Turtle Lake quadrangle consists largely of silt; no evidence of bedding was seen in the few exposures that were observed. It forms soil here that is ideally suited to wheat farming, as it does throughout its entire extent in eastern Washington. As a result, even the smallest remnants of Palouse are cultivated. This cultivation makes the precise location of boundaries between the Palouse and sandy glacial deposits, or locally even between the Palouse and deeply weathered granitic rocks, difficult. The contact between the Palouse and the underlying Columbia River basalt is generally easily located within a few tens of feet because of the difference in resistance to erosion of the two formations. The Palouse erodes easily and produces gentle slopes, whereas the Columbia River basalt is quite resistant and forms steep slopes; for example, see the slopes along Indian Creek (pl. 1). Thus, there is commonly a sharp break in slope at the contact. However, the actual contact with older rocks is usually covered by vegetation and is well exposed only in the road cuts mentioned above and in a shallow road cut in the southeastern corner of the map area, along the boundary line between sec. 10 and 15, T. 26 N., R. 38 E. No section of the Palouse where it overlies the basalt or where it is more than 5 feet thick was observed, and thus no comprehensive description of the composition of formation has been attempted.

Along the northern margin of the Palouse formation south of the Spokane River, pebbles, cobbles, and boulders are mixed with silt of the Palouse. All the mixed silt and gravel deposits are on the north side of the drainage divide south of the Spokane River. East of point A (fig. 6) the upper elevation of the deposits is within a few feet of the 2,480-foot contour line. Northwest of this point the mixed silt and gravel extend up to an elevation of almost exactly 2,600 feet. The belt of mixed deposits, everywhere it has been recognized, is under cultivation at present or has been cultivated in the past; so the true relation between the silt and gravel is not known. It now consists of sparse well-rounded pebbles, cobbles, and subrounded boulders of metamorphic rocks, granitic rocks, and, locally, basalt mixed with the silt. The pebbles, cobbles, and boulders make up only a rather small part of the deposit-commonly only a few are exposed per hundred square feet. North of the river, 
many isolated unweathered boulders similar to those described earlier rest on deeply weathered granitic rocks below 2,600 feet in elevation, but none have been observed above this elevation. The exact correspondence of the upper level at which the boulders are found and the lack of evidence of glacial erosion in the deeply weathered granitic rocks north of the river suggest that the pebbles cobbles, and boulders were ice-rafted in a lake rather than deposited directly by a glacier.

Several channels that appear to have served as outlets for the lakes have been cut through the Palouse formation and into the underlying basalt a few feet. These are best shown east of Indian Creek in secs. 5, 8, and 17, T. 26 N., R. 37 E. (pl. 1 and loc. A, fig. 6). Reconnaissance south and west of the Turtle Lake quadrangle indicates that the drainage from the southeastern lake flowed into Indian Creek, then northwestward to the large scabland channel west of Davenport; none of the channels extend southwestward beyond the Indian Creek basin (for a detailed discussion of the scabland channels and their development, see Bretz and others, 1956, p. 957-1049).

On the south slope of Lilienthal Mountain are three small areas of silt that contains angular fragments of quartzite and phyllite. The silt appears to be the same as that making up the Palouse formation farther south, and the metasedimentary rocks are fragments of the rocks exposed on the top of Lilienthal Mountain. These are the only areas in the quadrangle where colluvium was observed mixed with silt of the Palouse. Below 2,600 feet elevation rounded pebbles and cobbles of many rock types are mixed with the silt and colluvium. These pebbles and cobbles are part of the glacial lake deposits described earlier.

\section{GLACLAL DEPOSITS UNDIVIDED}

A tremendous amount of sand and gravel has been deposited along the valley of the Spokane River by glacial melt water. No attempt was made to divide this deposit into subunits, although some subdivision could be made from an intensive study of this and surrounding areas. The details of the sand and gravel deposit are well exposed in landslide scarps at several places along the steep banks of Franklin D. Roosevelt Lake. The deposit is well bedded with beds ranging in thickness from a few inches to many feet. Some of the beds are well-sorted clay, silt, or sand, and others are poorly sorted sand and gravel, commonly with cobbles as much as 6 inches in diameter and including a few boulders, some several feet in diameter. A few of the gravel beds along the river valley are crossbedded. The crossbedding is quite regular and not the highly irregular festoon-type crossbedding common along stream channels. 
The deposit is well exposed along the west side of Mill Canyon in $\mathrm{SE} 1 / 4$ sec. 7, T. 26 N., R. 38 E. Mill Canyon was first partly filled by well-bedded sand and gravel. Later, a steep-walled valley about 50 feet deep was cut in the deposit and subsequently filled with similar well-bedded sand and gravel. Finally, the present Mill Canyon was cut through both deposits.

Along the shores of Franklin D. Roosevelt Lake from the eastern map boundary to about point B (fig. 6), the deposit appears to consist largely of beds of clay and sand. Farther north along the west shore of the lake between points $\mathrm{B}$ and $\mathrm{C}$ (fig. 6), it includes many beds of poorly sorted gravel and sand. Farther northwest the deposit appears to be predominantly beds of sand with subordinate gravel and clay beds.

In the valley of the Spokane River the deposit has a minimum thickness of about 300 feet. It may have been as much as 200 feet thicker, but post- or late-Pleistocene erosion by water and wind has considerably modified the top of the deposit, and thus the actual thickness is not known.

The sediments at the top of the deposit have been considerably reworked by wind. Stationary dunes are well displayed near the mouth of Harker Canyon in the N1/2 sec. 36, near the south end of Sand Flat in the NW1/4 sec. 26 and NE $y_{4}^{\prime}$ sec. 27 , and north of the Lowley Lease in S 12 sec. 12 and N1/2 sec. 13, T. 27 N., R. 37 E. The small hills shown by closed contour lines southwest of Cayuse Mountain in the SW corner sec. 19 and NE corner sec. 20, T. 27 N., R. 38 $\mathrm{E}$., are also windblown sand deposits. The wind-deposited sand is well exposed in bulldozer cuts at several places north of the river, where it includes sparse, well-polished ventifacts, some of which are as much as $2 \frac{1}{2}$ inches long. The thickness of the windblown sand deposit excluding the dunes ranges from less than 1 foot to about 10 feet.

A poorly sorted deposit of coarse gravel, sand, and clay at least 20 feet thick is exposed in a small valley near the southeast corner of the map area (point $\mathrm{D}$ in fig. 6 ) in the $\mathrm{SE}^{1 / 4} \mathrm{sec}$. 4, T. 26 N., R. $38 \mathrm{E}$. Similar material appears to underlie most of the area shown as glacial deposits undivided on plate 1 in this vicinity. The boulders include many different rock types, both igneous and metamorphic, but basalt appears predominant. The boulders are mostly less than 1 foot in diameter and most are subangular. Very few are well rounded. This area is at the southwest end of a broad but rather shallow channel cut through the Palouse into the underlying metamorphic rocks and basalt. The channel appears to have been cut by melt water, probably from an ice lobe northeast of the map area, and the gravel, 
sand, and clay may have been deposited where these melt waters emptied into a glacial lake.

Also near point D (fig. 6) in the southeastern corner of the map area $\left(\mathrm{NW}_{1 / 4}\right.$ sec. 10) a rather broad ridge of poorly exposed material that appears to be dominantly sand, silt, and small angular rock fragments with a few large boulders of Gerome intrusive rock, dams a small valley forming an undrained depression large enough to be shown by the contour lines on plate 1 . This may be a moraine, and if so, it is the only moraine recognized south of the Spokane River in the map area.

North of the Northwest Uranium mine (point E, fig. 6) in sec. 35 and NE corner sec. 34, T. $28 \mathrm{~N}$., R. 37E., is another deposit of sand and coarse gravel. The deposit is at least 12 feet thick as exposed in bulldozer cuts, and might be considerably thicker in places. A typical section as exposed in one trench has 6 to 12 inches of light-brown silt and sand at the surface; this is underlain by 3 feet of crossbedded gravel and sand; underlying this is moderately well sorted, fine to coarse sand in horizontal beds. The pebbles and cobbles are subangular to subrounded and as much as 6 inches in diameter. They include granitic rocks, aplite, tuff, and quartzite. The crossbedding dips consistently toward the northwest. The sand grains are not well rounded and consist of rock fragments and broken mineral grains. The sediments appear to have been deposited by an ice marginal stream that may have been flowing northwesterly, but more exposures would be necessary to be certain of the direction that the stream flowed.

Glacial erosion is evident northeast and east of Cayuse Mountain (point F, fig. 6). The soil and weathered granitic rock have been removed and fresh granodiorite is exposed in elongate outcrops along numerous northeast-trending ridges (fig. 7). Many small ponds occupy narrow closed depressions, some of which are as much as 40 feet deep, between these ridges. The ice did not extend over the top of Cayuse Mountain, and a relatively deep residual soil covers the Paleozoic(?) metamorphic rocks above an elevation of about 2,450 feet. Nor did the ice override the small hill northeast of Cayuse Mountain in the northeast corner of sec. 15, T. 27 N., R. 38 E., but apparently it extended up to about 2,500 feet in elevation on the northeast and southeast side of the hill. Below this elevation are a few unweathered outcrops of bedrock, but none were observed above this elevation. Northwest of this area at point G (fig. 6) a remarkably sharp line of demarkation between deeply weathered granodiorite and relatively fresh, scoured-appearing outcrops of granodiorite extends southwestward across secs. 3, 4, and 8. At the edge of the quadrangle in sec. 3 the line is at an elevation of about 2,500 feet and 


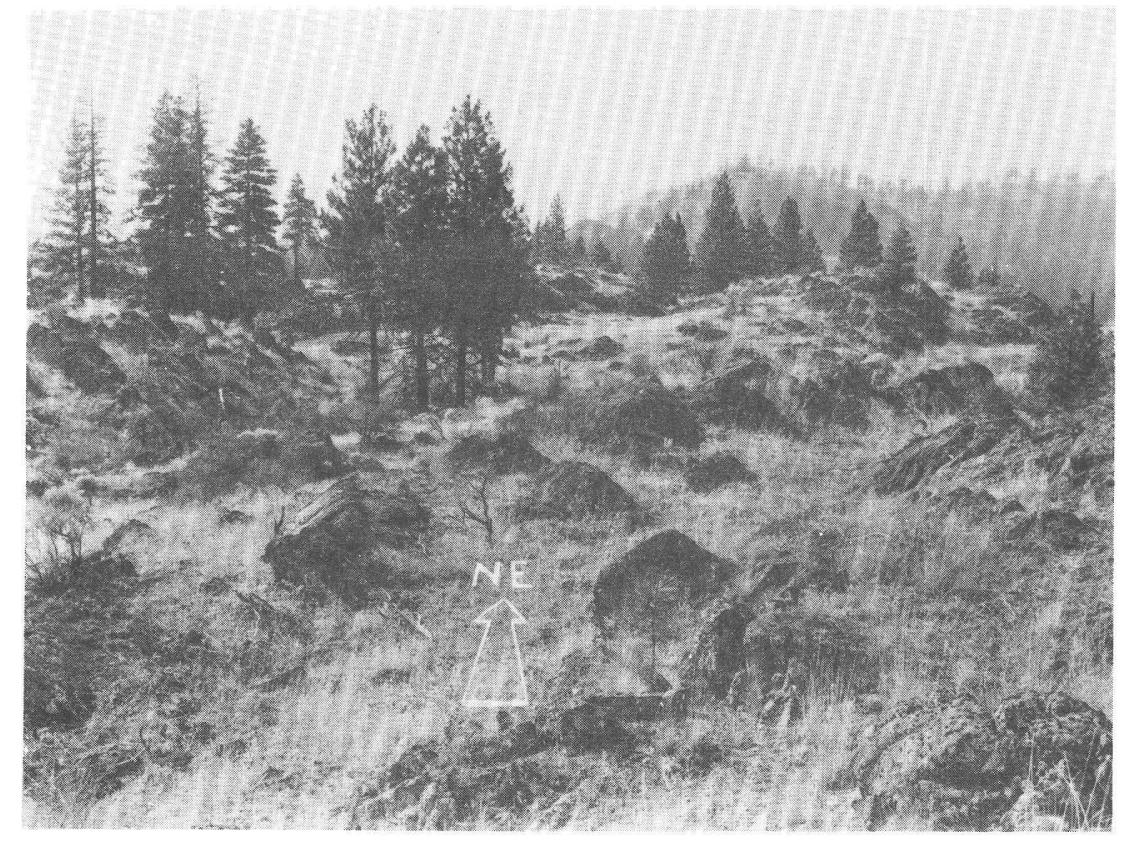

FIGURE 7.-Glaciated outcrops of granodiorite northeast of Cayuse Mountain. The granodiorite has been scoured by glacial ice leaving fresh rock and elongate depressions which show that the ice moved across the area from the northeast.

it descends to an elevation of about 2,350 feet in the $\mathrm{NE} / 4$ sec. 8 . This line is apparently the margin of the ice in this area.

Flint (1936, p. 1856-57) states that channels near Benjamin Lake (south of point G, fig. 6) in secs. 2 and 3, T. 27 N., R. 38 E., have been stream plucked and stream scoured and were probably outlets of a lake lying north of this area. These may have been outlets, but the evidence of glacial deposition and erosion farther south and west strongly suggests that these channels were formed by glacial erosion. They may have been slightly modified later by drainage from the lake.

\section{GLACLAL MORAINE}

North of the Spokane River, poorly sorted to unsorted and poorly stratified to unstratified deposits of gravel, sand, and silt that are probably largely moraine have been mapped in four areas. The deposits are very poorly exposed and appear generally quite thin.

The deposits are composed of a wide range of igneous and metamorphic rocks, including some rock types that do not crop out in the Turtle Lake quadrangle. The material ranges from silt sized fragments to boulders as much as 4 feet in diameter. The coarser rocks are generally rounded to subangular. In places, lenses a few 
feet thick and 20 to 30 feet long are moderately well sorted and stratified.

\section{GLACIAL LAKE SIIT}

Lacustrine silt covers about $3 \frac{1}{2}$ square miles along the northeastern edge of the quadrangle. The silt was deposited in the Pleistocene lake named Lake Wellpinit by Flint (1936, p. 1856). The silt is ash gray and is generally well sorted and unconsolidated. It contains a few widely scattered boulders that were probably ice-rafted to their present positions. The maximum thickness of the silt is not known but probably does not exceed 100 feet. The area underlain by the silt is densely brush-covered, and outcrops are extremely sparse, thus the margins of the silt are extremely difficult to trace. The silt appears to thin and disappear against the higher hills to the west and north at an elevation of about 2,600 feet. This is higher than the maximum elevation of 2,500 feet given by Flint for the deposit. The actual lake deposits may have been below 2,600 feet, and the silt at 2,600 feet may have been deposited by wind. After the lake was drained by destruction of the ice dam, the silt from the broad, flat lake basin almost certainly would have been reworked by the wind and some of it was probably redeposited along the margins of the lake basin. An alternative explanation might be that the lake originally reached a level of 2,600 feet and began to overflow westward through the Turtle Lake-Blue Creek valley. The outlet in the vicinity of Turtle Lake may have been cut down relatively rapidly to about 2,500 feet, leaving a thin veneer of silt above that elevation. Downcutting would have stopped when the outlet was cut down to 2,500 feet, if the lower Spokane River and Columbia River valleys were filled at the same time by a lake at the 2,500 foot level.

\section{QUATERNARY ALLUVIUM}

Quaternary alluvium covers small areas in some of the valleys that are tributary to the Spokane and Columbia Rivers. The most extensive deposits are those along parts of Indian Creek, Oyachen Creek, Blue Creek, Little Chamokane Creek, and Sand Creek. Most of the alluvium consists of coarse sand and gravel. The alluvium east of the Big Smoke mine in sec. 7, T. 27 N., R. 38 E., appears to have been deposited partly in a shallow lake dammed by windblown sand. Alluvium has also been deposited in a small closed depression in secs. 21 and 22 , T. 28 N., R. 37 E. The depression was apparently formed in basalt by Pleistocene floodwater.

\section{LANDSLIDES}

The construction of Grand Coulee Dam on the Columbia River formed Franklin D. Roosevelt Lake and raised the water table consid- 
erably above its former level along the Spokane River valley. The elevated water table caused movement in unconsolidated Pleistocene sediments in several places (Jones, Embody, and Peterson, 1961). This resulted in three landslides in the Turtle Lake quadrangle that are large enough to be seen from great distances. They are near the mouth of Harker Canyon in sec. 36, T. 27 N., R. 38 E., west of Lowley Lease in sec. 15 , T. 28 N., R. 36 E., along the south side of the river, and north of the mouth of Sand Creek in sec. 17, T. 28 N., R. 37 E., on the north side of the river. Each of the three slides has moved many tens of thousands of cubic yards of sand, silt, and gravel. Movement on at least one, the slide on the north side of the river, was continuing through the spring of 1957 .

\section{STRUCTURE}

FOLDS

The metasedimentary rocks in the northern part of the Turtle Lake quadrangle form the southwestern end of the Deer Trail anticline, a north-northeast-trending structure about 30 miles long that was first recognized by Weaver (1920, p. 108). Only the west limb of the anticline is present in the quadrangle. This limb dips steeply to the west in much of the quadrangle, but in places, as at the Midnite mine in secs. 1 and 12, T. 28 N., R. 37 E., it is overturned, and its dips range from $55^{\circ}$ to $75^{\circ} \mathrm{E}$. The trend of the anticline in most of the map area ranges from about N. $10^{\circ}$ E. to N. $20^{\circ}$ E. Irregular, small-scale folds are present in only a few places, where they are superimposed on the generally regular trends of the major structure.

\section{FAULTS}

Metamorphic rocks in the northern part of the quadrangle are cut by several faults (pl. 1). A zone of intensely sheared phyllite of the Togo formation about 200 feet thick is exposed in a road cut in the SE $1 / 4$ sec. 30 , T. 29 N., R. 38 E. In the road cut the shear zone strikes about $\mathrm{N} .15^{\circ} \mathrm{W}$. and dips about $80^{\circ} \mathrm{E}$., nearly parallel to the regional strike and dip of the metamorphic rocks; about three quarters of a mile to the north the strike changes to a northeasterly direction. The zone does not extend south of Sand Creek. The amount and direction of displacement could not be measured.

A similar shear zone extends for about $1 \frac{11}{4}$ miles northeast from the southwest edge of sec. 25 , T. 29 N., R. 37 E. It is at least 10 feet wide in places. It strikes N. $5^{\circ}$ to $40^{\circ} \mathrm{E}$. and dips steeply. Direction and amount of displacement along this shear zone is not known. The shear zone appears to terminate against bodies of Loon Lake granite at both ends, and we saw no evidence of postgranite movement. 
The metasedimentary rocks in the southeastern part of the map area appear to be part of the southwest limb of a southeastward- or eastward-plunging syncline. In general the bedding south of the river and near the southeastern part of Cayuse Mountain has a northwest strike and dips toward the northeast. Northwest of Cayuse Mountain the strike of the bedding changes to a general northnortheast direction and the dip is toward the southeast. Local differences in the structure are probably due to later faults or minor folds superimposed in the regional structure.

Emplacement of the Loon Lake granite caused deformation of the metamorphic rocks in places. Strikes and dips of metamorphic rocks are divergent from regional trends locally near the intrusive contact, but apparently the intrusion did not cause widespread, large-scale deformation of the older rocks.

Three north-striking faults were mapped in secs. 1 and 12, T. 28 N., R. $37 \mathrm{E}$., in the igneous and metamorphic rocks along the east side of the Midnite mine. Two could be traced only a few hundred feet from the point where they offset the contact between the quartz monzonite and the Togo formation near the south boundary of sec.12. Both of these faults strike nearly north, and dip steeply. The east side has been downthrown on both faults. The third fault is exposed in a bulldozer cut near the north edge of sec. 1 . The fault strikes N. $5^{\circ} \mathrm{W}$., and dips vertically. Movement along this fault has brought argillite on the east side into juxtaposition with thermally metamorphosed phyllite on the west. The vertical component of displacement along this fault is inferred to be at least 300 feet (east side down), the minimum thickness of the thermally metamorphosed aureole surrounding the porphyritic quartz monzonite in this vicinity.

Faults having small displacement cut quartzites in the Edna dolomite and Togo formation in several places in secs. 22, 27, 33, and 34, T. 29 N., R. 37 E. The faults have a general westward strike and dip steeply. The north sides of the faults in secs. 22, 27, and 34 have been offset 25 feet to 250 feet to the east.

The metasedimentary rocks on Cayuse Mountain are cut by three conspicuous faults. The direction of movement and amount of displacement along these faults are unknown, but almost certainly the movement has been several hundred feet. The western fault is covered at each end by Pleistocene sand and gravel. The middle and eastern faults extend at least to the contact between the granodiorite and the metamorphic rocks; whether they extend into the granodiorite is not known because of lack of exposures in the vicinity. The middle fault possibly displaced the contact a short distance, but 
poor exposures leave this uncertain. The middle fault dies out southward in the marble, and the southern part of the eastern fault is covered by sand deposits.

At the Northwest Uranium mine pyroclastic and sedimentary rocks of the Gerome andesite are cut by a north-trending nearly vertical fault (fig. 8). The west block moved downward about 300 feet.

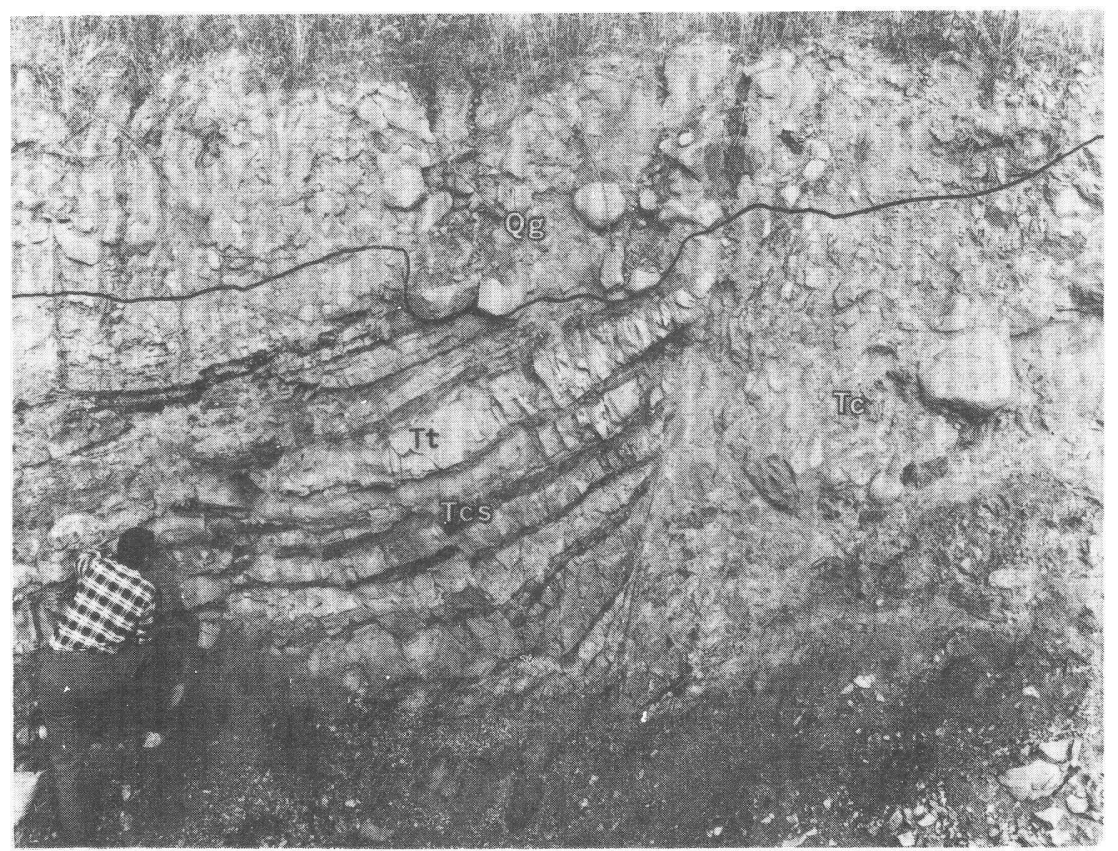

Figure 8.-Fault in the Gerome andesite, Northwest Uranium mine. Tc, conglomerate; Tt, tuffaceous sandstone; Tcs, carbonaceous shale; Qg, glacial deposit

Faults also were observed at the Big Smoke mine and Lowley Lease but could not be traced beyond the margins of the mine workings because of lack of bedrock exposures.

\section{JOINTS}

Joints cut all of the igneous and metamorphic rocks in the Turtle Lake quadrangle, but in most places they form no discernible pattern. Joints in intrusive igneous rocks are generally widely spaced and of random orientation. Metamorphic rocks are typically cut by joints that make a considerable angle with bedding, but which could not be related to any major structure. The Gerome andesite and Columbia River basalt flows are typically cut by great numbers of closely spaced, irregular cooling joints. 
Prominent cleavage was noted in two formations in the northern section-the phyllite of the Togo formation and the McHale slate.

The phyllite of the Togo has fair to good bedding cleavage in almost all exposures. Locally, the rock is also cut by cleavage at an angle to the bedding. The McHale contains fair to good cleavage in all exposures in the quadrangle.

\section{GPOKANE RIVER VALLEY-ENTERPRISE VALLEY LINEAMENT}

The Spokane River valley-Enterprise Valley lineament ${ }^{3}$ extends diagonally across the entire Turtle Lake quadrangle along a line that trends about $\mathrm{N} .30^{\circ} \mathrm{W}$. At the south end, the lineament is filled by volcanic rocks of the Gerome and Columbia River; to the north it continues for about 2 miles beyond the Turtle Lake quadrangle to the valley of the Columbia River. The fact that the Gerome andesite is almost entirely confined to this 2- to 4-mile-wide trough suggests that the valley may have existed at least as early as Oligocene time.

Certain features suggest that the lineament is a fault or a fault zone. The Cambrian-Precambrian boundary on Lilienthal Mountain is more than a mile west of where it would be expected if its strike were projected from exposures north of the Spokane River. Also the Addy quartzite-Old Dominion limestone of Weaver contact is displaced westward at least a mile on the southwest side of the Spokane River valley-Enterprise Valley lineament. The dikes of Gerome andesite, which are largely restricted to the area of this lineament, and which have a dominantly northward to northwestward trend, may bave been intruded along fractures associated with the major fault. No exposures of a fault were found along the axis of the lineament, but most of the area is covered with Pleistocene sand and gravel or is below the level of Franklin D. Roosevelt Lake. The extension of the valley to the north has not been mapped, but no evidence of faulting was noted there during brief reconnaissance. No evidence of faulting was found in exposures of Gerome rocks along the north bank of the Spokane River at the point where the river swings west to leave the axis of the lineament.

\section{GEOLOGIC HISTORY}

Precambrian stratigraphic history has been discussed briefly (p. 15). The Precambrian rocks in the Turtle Lake quadrangle resemble in appearance, composition, and degree of metamorphism the rocks of Belt age in adjacent parts of Washington and Idaho. Features indicating shallow-water deposition are rare. Some of the quartzite shows sparse crossbedding, and ripple marks were found in one place.

${ }^{3}$ Lineament is used in the sense of a topographic line that is structurally controlled. 
Facies changes or sedimentary features that would indicate the direction from which the sediments came were not detected in the rocks exposed in the map area.

The Precambrian rocks were slightly deformed before the deposition of the Addy quartzite. Local, small-scale folding is present in a few places, and faults with as much as 250 feet of horizontal displacement cut Precambrian rocks, but cannot be traced into younger rocks (pl. 1).

The Lower Cambrian Addy quartzite appears to have been deposited on a virtually flat surface. The quartzite contains abundant crossbedding and a few ripple marks; evidently it was formed partly in shallow water. Weaver's Old Dominion limestone was laid down on the Addy with no apparent break in deposition.

The folding that produced the Deer Trail anticline may have taken place during late Mesozoic time, although dating of the orogeny is not possible on the basis of present knowledge. After the major period of folding the Loon Lake granite was emplaced. The granite is generally considered Cretaceous in age, but again precise dating is not possible based on present data.

Following a period of considerable erosion, the Gerome andesite was deposited-probably during Oligocsne time. The rocks of the Gerome andesite are now confined to the Spokane River and Enterprise valleys, but may have originally covered a considerably larger area. Faulting probably took place along the Spokane and Enterprise valleys before the deposition of the Gerome. The faulting continued after the Gerome was deposited, as indicated by the fault at the Northwest Uranium mine. Later in the Tertiary, probably during Miocene time, Columbia River basalt was deposited, covering much of the southern part of the quadrangle and extending northward in the area of the present Spokane River valley beyond the center of the map. Basalt flows also extended up large valleys east and west of the quadrangle. The Columbia River basalt in the vicinity of Turtle Lake in the northeast part of the map is part of one of these flows. The present course of the Spokane River was probably developed at this time.

During Pleistocene time the loess of the Palouse formation was deposiied over much of the southern part of the quadrangle. Later in the Pleistocene, continental glaciers extended into the quadrangle and dammed the Spokane River, forming lakes in the Spokane River Valley that drained southwestward for a short time, cutting channels in the Palouse formation. The river was later dammed at least one more time, at a lower level, by ice farther downstream west of the quadrangle, and gravel, sand, and silt at least 300 feet thick were 
deposited. Subsequent erosion by the Spokane River has removed much of this fill.

\section{MINERAL DEPOSITS}

\section{GENERAL STATEMENT}

The TCurtle Lake quadrangle contains a variety of mineral deposits. Ore has been produced from only a few, and except for the recently discovered uranium mines, the deposits appear to be small. The deposits are listed below and shown on plate 1:

1. Midnite mine. Secs. 1 and 12, T. 28 N., R. 37 E.

2. Northwest Uranium mine. Sec. 35 , T. 28 N., R. 37 E.

3. Big Smoke mine. Sec. 11, T. 27 N., R. 37 E.

4. Lowley Lease. Sec. 13, T. 27 N., R. 37 E.

5. Deer Mountain prospect. Sec. 21, T. 29 N., R. 38 E.

6. O-Lo-Lim mine. Sec. 9 , T. 28 N., R. 37 E.

7. Spokane Molybdenum mine. Sec. 32 , T. 28 N., R. 37 E.

8. Orazada mine. Sec. 27, T. 29 N., R. 37 E.

9. Valley View mine. Sec. 32 , T. 28 N., R. 37 E.

10. Fouress (4-S) mine. Sec. 32, T. 28 N., R. 37 E.

11. Matherly prospect. Secs. 4 and 9 , T. 27 N., R. 37 E.

12. Turtle Lake prospect. Sec. 16, T. 28 N., R. 38 E.

13. Germania Consolidated mine. Secs. 23 and 26, T. 29 N., R. 37 E.

14. Silica deposit. Sec. 6, T. 27 N., R. 37 E.

15. Barite prospect. Sec. 22 , T. 29 N., R. 37 E.

16. Coal prospect. Sec. 8 , T. 28 N., R. 37 E.

Most of the mines and prospects in the quadrangle were worked before 1920, and most underground workings are now inaccessible. Huntting (1956) and Valentine (1949) have compiled all available information on such properties, and much of the following information on individual properties is from their compilation.

Mining activity began in southern Stevens County about 1900, and by 1910 several deposits were being worked in the area immediately north of the Turtle Lake quadrangle.

Early prospecting in the quadrangle concentrated on base and precious metal lode deposits in an effort to dicover deposits similar to those north of the Spokane Indian Reservation. As a result, almost every sulfide-bearing quartz vein exposed was explored, at least slightly.

Exact dates of the first mining operations in the quadrangle are not known, but Patty (1921, p. 160) states that the O-Lo-Lim mine was first worked in 1917. Exploration at the Germania Consolidated mine probably began about this time. Between 1917 and 1954 prospecting was active, but only four deposits report any production, and only two, the Germania Consolidated and O-Lo-Lim mines, report production values in excess of $\$ 5,000$. Neither deposit was mined continuously for more than a few years. 
The uranium deposit at the Midnite mine was discovered in the spring of 1954, and the announcement of its discovery was followed by intensive prospecting throughout the area. As a result of this renewed prospecting activity, four additional deposits of uranium have been found.

\section{URANIUM}

\section{GENERAL FEATURES}

Three of the uranium deposits in the Turtle Lake quadrangle-- the Midnite mine, Lowley Lease, and a small prospect near Deer Mountain in the northeastern corner of the map-are in metasedimentary rocks along contacts with the Loon Lake granite, and two depositsNorthwest Uranium and Big Smoke mines-are in pyroclastic and sedimentary rocks of the Gerome andesite. Although the rest of the quadrangle has been extensively prospected, no other uranium has been found except traces at the Spokane Molybdenum mine. Much of the following information on the uranium minerals at the Midnite mine is based on work done by Robert G. Coleman of the U.S. Geological Survey.

\section{MIDNTTE MINE}

The Midnite mine (pl. 1, No.1) is in secs. 1 and 12, T. 28 N., R. $37 \mathrm{E}$., along the contact of the Togo formation and porphyritic quartz monzonite of the Loon Lake granite. The mine was mapped as part of the present study during August 1957 and was visited occasionally until June 1958. In 1957, five ore bodies were being mined by open pit (pl. 3), and other ore bodies were known but were not completely outlined by diamond drilling. Individual ore bodies are as much as 700 feet long, 200 feet wide, and more than 150 feet deep (Sheldon, 1959). All of the ore came from the oxidized zone and only a minor amount of unoxidized ore was observed but more was indicated at depth by diamond drilling.

In the oxidized zone, the uranium has been redistributed by ground water, and the secondary uranium minerals are ubiquitous, the greatest concentration being along fractures. Almost all of the uranium is in the metasedimentary rocks, and only in the ore body at the Adit pit (pl. 3) were secondary uranium minerals sufficiently abundant in the quartz monzonite to constitute ore. Elsewhere along the contact, the quartz monzonite contains only sparse amounts of secondary minerals adjacent to ore bodies in the metasedimentary rocks.

The metasedimentary rocks range considerably in composition and grain size. They are principally thin-bedded, spotted schist and phyllite containing spongy andalusite xenoblasts, quartzose phyllite, and mica schist, and a few thin beds of relatively pure quartzite. The schist contains abundant muscovite, much of which is oriented parallel to the schistosity, but some large muscovite porphyroblasts 
have a random orientation, partcularly near the contact with the granitic rocks. The matrix of the rock is fine grained and consists largely of quartz and muscovite. Accessory tourmaline and rutile are abundant. Near the granite contact in Hill No. 3 pit, large potassium feldspar porphyroblasts occur in the schists. These are restricted to a zone less than a foot wide adjacent to the contact. The quartzite is almost entirely equigranular quartz, but some of it contains a small amount of mica. Near the contact with the granitic rocks the quartzite has been so thoroughly recrystallized that it resembles quartz veins, but the granular texture preserved locally indicates that they were originally sandstone lenses in the sediments.

Dikes of mentamorphosed mafic igneous rocks are also present in the mine area. The dikes are probably Precambrian greenstone that has been thermally metamorphosed. The dike rocks are somewhat coarser grained in the vicinity of the mine than they are farther away from the contact and consist largely of plagioclase and hornblende. The largest dikes are shown on plate 3 in the Boyd No. 1 pit. No uranium ore was observed in these dike rocks.

An extremely fine grained hornblende-quartz rock occurs near the southeast margin of Hill No. pit. The rock consists of hornblende crystals of poorly developed orientation set in a groundmass that is largely quartz. This hornblende-quartz rock does not have a typical hornfels texture, but some of the schistosity of the original rock has been destroyed by metamorphism apparently related to the intrusion of the granitic rock.

The metasedimentary rocks have a general northward strike and dips range from about $35^{\circ} \mathrm{E}$. (overturned) to vertical. East of the westernmost fault on the road east of Pit No. $2 \mathrm{E}$ (pl. 3) the beds dip from $35^{\circ}$ to $80^{\circ} \mathrm{W}$., suggesting that there has been considerable movement along the fault. The direction and amount of the movement is unknown. The rocks are cut by many other small faults, most of which are nearly vertical except where they pass into bedding plane faults that have more shallow dips. Some of the faults are later than the emplacement of the granite and offset the Togo formation porphyritic quartz monzonite contact, but most are probably older than the granite.

The porphyritic quartz monzonite in the mine area is coarse grained and contains large potassium feldspar phenocrysts except within a few feet of the contact. Locally along the contact the rock is finer grained. The contact is sharp and in detail is extremely irregular. It commonly crosscuts the bedding of the metasedimentary rocks but locally parallels the bedding. The dip of the contact ranges considerably but in general the dip is eastward and relatively steep in the Hill No. 3 pit area, and relatively shallow in the Adit pit area. Many 
small granitic dikes extend into the metasedimentary rocks in Hill No. 3 pit and Pit No. 2W, but none were observed in the Adit or Boyd No. 1 pits.

The highest grade ore is localized along zones in which the bleached metasedimentary rocks are altered to a rock consisting largely of clay, quartz, and sericite. These zones are generally at or within a few feet of the contact between the quartz monzonite and metasedimentary rocks. Some smaller zones are along faults at a considerably greater distance from the contact, particularly in Hill No. 3 pit. The quartz monzonite adjacent to these zones is largely unaltered except for the plagioclase, which is altered to sericite and clay. The biotite and potassium feldspar are generally fresh.

Only sparse secondary uranium minerals along fractures have been observed in the unaltered rocks outside these zones, except for some ore in the unaltered quartz monzonite that lies beneath the altered metasedimentary rock in the Adit pit. There meteoric water moving downward apparently leached uranium from the ore body in the metasedimentary rocks and deposited it in many fractures in the underlying quartz monzonite.

The secondary uranium minerals in the oxidized zone are generally associated with iron oxide films and coatings. In most places the deposits are a mixture of several secondary minerals, but local monomineralic concentrations are found along some fractures. The individual crystals are commonly very small; the maximum size is generally less than $0.5 \mathrm{~mm}$. Locally along fractures, particularly in the southwest part of Hill No. 3 ore body, some meta-autunite crystals are as much as $5 \mathrm{~mm}$ in diameter, but crystals of this size are uncommon.

Meta-autunite is by far the most abundant secondary mineral at the mine. In the ore bodies it commonly forms thin films made up of overlapping plates on closely spaced fractures; also in ore bodies and in the surrounding rock it forms discrete greenish crystals on iron oxide. In most specimens there appear to be several generations of meta-autunite.

The next most abundant secondary uranium mineral is uranophane. It is in extremely fine, fibrous crystals forming thin films on fracture surfaces and is easily distinguished from meta-autunite by its lack of fluorescence. In some specimens uranophane is intergrown with phosphuranylite.

Phosphuranylite commonly forms very thin orange-yellow coatings on fractures, intimately intermixed with iron oxide. This mode of occurrence is a handicap in the indentification of the mineral because a pure concentrate is difficult to obtain. The relative abundance is also difficult to determine for the same reason. 
Associated with uranophane are small pincushion-like clumps of a yellow-brown prismatic mineral that is most probably sklodowskite. Liebigite was identified in one specimen from Pit No. $2 \mathrm{~W}$ by Jerome Stone (written communication, 1956), U.S. Geological Survey.

In the few specimens of unoxidized ore that we observed the uranium minerals are uraninite and coffinite. These minerals are intimately associated with pyrite and marcasite in fractures. The uraninite is principally the fine-grained, sooty variety; wellcrystallized, dense uraninite was observed in only one specimen. X-ray and spectrographic determinations confirmed the identification of uraninite and indicated the presence of coffinite. Most of the uraninite and coffinite observed in the mine during the present study was in a vein about 2 feet wide near the center of Hill No. 3 pit. The vein was bounded on each side by faults containing from $1 / 2$ to 2 inches of gouge. Not enough unoxidized material was available during the present study to make a complete evaluation of the primary ore.

For additional information on the mineralogy of the ore at the Midnite, the reader is referred to a detailed discussion by Barrington and Kerr (1961), which was published after this report was completed.

Total reserves at the Midnite mine are unkown. Some idea of the size of the deposit can be gained, however, from production figures given by Sheldon (1959). He states that mining began in the spring of 1957, and during that year 592,000 tons of waste was stripped, 164,000 tons of ore was mined, and 151,000 tons of lowgrade ore was stockpiled. Mining continued at about the same rate through 1958. The ore is trucked 22 miles to Ford, Washington, where it is treated at the 440-ton Dawn Mining Company mill (Hargrove, 1958).

Determinations of $\mathrm{Pb}^{206} / \mathrm{U}^{238}$ and $\mathrm{Pb}^{207} / \mathrm{U}^{235}$ ratios were made by Loren Stieff and Thomas Stern of the U.S. Geological Survey, using unweathered uraninite-bearing ore from the Midnite mine. The lead: uranium ratios suggest ages of 102 million years and 108 million years, respectively, for the deposit. Because the uraninite occurs in fractures and is dominantly the sooty variety, some of the uranium might have been leached by ground water. If so, the deposit is younger than these suggested ages (Thomas Stern, oral communication, 1960).

The history of the deposit appears to be as follows: Shortly after emplacement of the granitic rock, uranium-bearing hydrothermal solutions deposited uraninite, coffinite, pyrite, and marcasite along structurally favorable zones in the metasedimentary rocks adjacent to the contact. The metasedimentary rocks were altered to a rock 
consisting mainly of clay, quartz, and sericite. Some of the solutions also followed faults in the metasedimentary rocks and deposited uranium at a considerable distance from the contact. Later, meteoric water redistributed the uranium slightly in the zone of oxidation, and secondary uranium minerals and iron oxide were deposited in the rocks adjacent to the original veins.

\section{NORTHWEST URANIUM MINE}

The Northwest Uranium mine is in gently dipping pyroclastic and sedimentary rocks of the Gerome in SW $1 / 4$ sec. 35, T. 28 N., R. 37 E. (pl. 1, No. 2). The uranium deposit was discovered in 1955 during an airborne scintillation-counter survey of the area. The original ground discovery was of outcrops of thin, slightly radioactive, carbonaceous shale beds that were not of ore grade. The mine area was mapped in 1956 by Weis and Donald F. Kellum, U.S. Geological Survey, as part of an examination for a Defense Minerals Exploration Administration contract (Docket 4125). The geologic map (pl. 4) was completed by Becraft in 1958.

In 1957 the mine area had been explored by many bulldozer trenches, percussion-drill holes, and diamond-drill holes. As a result of the drilling, most of which was done as part of the Defense Minerals Exploration Administration contract No. IDM-E964, a large lowgrade uranium ore body was outlined. The ore consists of uraninite intimately associated with carbonaceous material near the base of a conglomerate that makes up the basal unit of the Gerome andesite in this vicinity. The ore body consists of the part of the conglomerate that contains the uraninite-bearing carbonaceous material. The maximum thickness of the ore body is believed to be as much as 30 feet. It lies from a few feet to as much as 80 feet below the surface.

Early in the summer of 1958 , open-pit mining operations were begun. A pit extending northeastward from the steep wall of the Spokane River valley intersected the southwest margin of the large low-grade ore body about 90 feet below the surface (pl. 4). Ore from this pit was shipped by truck to the Dawn Mining Company's uranium mill at Ford, Wash.

In the mine area the Gerome andesite consists of interbedded tuffaceous sandstone, arkose, and carbonaceous shale overlying a thick, poorly sorted conglomerate. In the upper part of the sequence the beds are generally less than 1 foot thick, but some of the arkose beds are as much as 6 feet thick. The basal conglomerate, which appears to be about 100 feet thick on the east side of the open pit, has only a faint suggestion of bedding in most places, but it does contain a few thin lenses of arkose containing much carbonaceous material. The conglomerate contains many cobbles and boulders as much as a foot 
in diameter and a few boulders as much as 8 feet in diameter in an arkosic matrix. The matrix generally makes up only a small part of the rock. The boulders are subangular to rounded and range considerably in composition but are mainly quartzite or types of Loon Lake granite. The conglomerate is very poorly cemented, and except for the large boulders that must be broken before removal, the rock can be mined without blasting. Compilation of drill-hole information by D. F. Kellum indicates the conglomerate occupies a shallow northwest-trending trough in the underlying porphyritic quartz monzonite (pl. 4). This trough may be a pre-Gerome andesite stream valley.

In the open pit, the uranium ore is bounded on the west by the large, steeply dipping, north-trending fault and on the south by an older east-trending fault (pl. 4). Drilling information indicates the ore body pinches out to the north, east, and probably to the south except in the vicinity of the pit. West of the north-trending fault, a few feet of uranium-bearing rock was cut by two diamond-drill holes at depths of about 365 feet in one hole and 425 feet in the other,

The only radioactive material in the ore zone is intimately associated with the abundant carbonaceous material. The carbonaceous material occurs both in small arkosic lenses and in irregular masses distributed sporadically throughout the conglomerate. All the carbonaceous material in the ore zone is highly radioactive. The ore zone extends from the bottom of the pit to about 30 feet above the bottorn. No carbonaceous material was observed in the conglomerate above the ore zone.

Three samples of highly radioactive coalified wood from the ore zone were analyzed by the U.S. Geological Survey. Much of the following information is summarized from a report by Irving A. Breger, U.S. Geological Survey (written communication, 1958).

All three samples exhibited excellent coalified woody structure, and all the samples included quartz, potassium feldspar, clay, and calcite. Two of the samples were from small lenses of arkosic sandstone and the other from an isolated piece of coalified wood in the ore zone. The samples were handpicked to remove as much as possible of the arkosic sandstone. Sample 8B39a was split into two samples; one of which had a brilliant bituminous luster and the other a dull black. The four samples were analyzed for equivalent uranium; they were then ashed and the amount of uranium in the ash was determined. Table 5 indicates that the equivalent uranium values are about onehalf the chemical values, but it is not possible to determine whether this represents disequilibrium because of relatively recent introduction of uranium, whether circulation of ground water has removed daughter 
products, or whether the counting technique, in which coal is compared to a rock standard, is not properly calibrated at the high uranium values.

TABLE 5.-Equivalent uranium and uranium analyses of carbonized wood from the Northwest Uranium mine

[In percent by weight]

\begin{tabular}{|c|c|c|c|c|}
\hline Sample No. & $e \mathrm{U}$ & $\mathrm{U}($ calc. $)$ & Ash & $\mathrm{U}$ in ash \\
\hline - & 0.74 & 1. 2 & 8. 82 & 13 \\
\hline 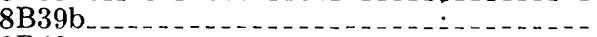 & 1. 7 & 3.5 & 13.8 & 25 \\
\hline & 1. 7 & 3. 7 & 12.2 & 30 \\
\hline $10-1-1$ & 2.8 & 5.6 & 14. 0 & 40 \\
\hline
\end{tabular}

Semiquantitative spectrographic analyses and X-ray analyses were carried out on the four samples. Cubic X-ray patterns were reported for samples $8 \mathrm{~B} 40$ and $8 \mathrm{~B} 39 \mathrm{ad}$. In view of the spectrographic analyses (table 6), the cubic patterns indicate the uranium mineral present is uraninite. Samples $8 \mathrm{~B} 39 \mathrm{~b}$ and $8 \mathrm{~B} 39 \mathrm{ab}$ did not give a cubic pattern, but since coals containing uraninite do not show the cubic

TABLE 6.-Semiquantitative spectrographic analyses ${ }^{1}$ of carbonized wood ash from the Northwest Uranium mine

[Figures are reported to the nearest number in the series $7,3,1.5,0.7,0.3,0.15$, etc., in percent. These numbers represent midpoints of group data on a geometric scale. Analyst: Katherine V. Hazel, U.S. Geol. Survey]

\begin{tabular}{|c|c|c|c|c|}
\hline & $8 B 39 a^{\prime}$ & $8 B 39 b$ & $8 B 40$ & 8B39ad \\
\hline $\mathrm{Si}_{\ldots} \ldots \ldots \ldots$ & $>10$ & 3.0 & 3.0 & 7.0 \\
\hline $\mathrm{Al}$ & .7 & .7 & .7 & 7 \\
\hline $\mathrm{Fe}_{-}$ & 3.0 & 10. & 7. 0 & 7. 0 \\
\hline $\mathrm{Mg}$ & .3 & 3 & 3 & .3 \\
\hline $\mathrm{Ca} \ldots \ldots \ldots$ & 3.0 & 7. 0 & 7. 0 & 3. 0 \\
\hline $\mathrm{Na}_{\ldots} \ldots \ldots$ & .015 & .015 & .015 & 015 \\
\hline $\mathrm{K}$ & .03 & .03 & .015 & 015 \\
\hline $\mathrm{Ti}$ & 7 & 03 & 03 & 03 \\
\hline$M_{n} \ldots \ldots \ldots$ & .015 & 07 & 03 & 03 \\
\hline $\mathrm{Ag}$ & 00015 & .00015 & 00015 & 00015 \\
\hline $\mathrm{As}_{\ldots} \ldots$ & 1. 5 & 3. 0 & 3. 0 & 3.0 \\
\hline $\mathrm{B}_{-}$ & .007 & 015 & .03 & 007 \\
\hline $\mathrm{Be}_{\ldots}$ & .003 & .007 & .007 & 003 \\
\hline $\mathrm{Ba}_{\ldots} \ldots \ldots$ & .03 & .015 & 015 & 015 \\
\hline $\mathrm{Cr}_{\ldots} \ldots \ldots \ldots \ldots$ & .007 & 007 & 007 & 007 \\
\hline $\mathrm{Cu}$ & .0015 & .0015 & 003 & 003 \\
\hline Ge & .007 & 0 & 0 & 0 \\
\hline $\mathrm{Li}_{\ldots}$ & .0015 & 0007 & 0003 & 0007 \\
\hline Lu & .007 & .007 & .007 & 015 \\
\hline Mo $\ldots \ldots$ & 3 & .15 & 0 & 3 \\
\hline $\mathrm{Nb}_{\ldots} \ldots \ldots$ & 03 & .03 & .03 & 03 \\
\hline $\mathrm{Ni}_{-\ldots \ldots} \ldots \ldots \ldots \ldots$ & .0015 & 0 & 0 & 003 \\
\hline Pb_ $\ldots \ldots$ & .0015 & .0015 & .0015 & 0015 \\
\hline $\mathrm{S}_{\ldots} \ldots \ldots \ldots$ & .0015 & .003 & .003 & 0015 \\
\hline $\mathrm{Sr}_{\ldots} \ldots \ldots \ldots$ & .07 & 0 & 0 & 0 \\
\hline $\mathrm{U}_{-\ldots} \ldots \ldots \ldots$ & $>10$ & 10 & & $\Omega ?$ \\
\hline$V_{1} \ldots \ldots$ & .03 & .03 & .03 & .03 \\
\hline$Y$ & .07 & 03 & .03 & .03 \\
\hline $\mathrm{Yb} \ldots \ldots$ & .007 & .003 & .003 & 003 \\
\hline $\mathrm{Zn}_{\ldots} \ldots$ & .015 & 03 & .7 & 7 \\
\hline $\mathrm{Z} r$ & .007 & .03 & .03 & 015 \\
\hline
\end{tabular}

1 Looked for but not found: P, Au, Cd, Ce, Co, Cs, Ga, Gd, Hf, Hg, Ho, In, La, Nd, Os, Pd, Pr, Pt, Rb, Re, Ru, Rh, Sn, Sm, Ta, Tb, $w$. 
pattern for samples containing less than about 3 to 5 percent, it seems likely that uraninite is present in these samples also. The X-ray analyses also indicated the presence of pyrite in the coalified wood.

The spectrographic analyses indicate concentrations of arsenic, molybdenum, and zinc. According to Rankama and Sahama (1950), these elements are commonly concentrated in coal, and thus the amounts in these samples are not unusual.

Sparse metatorbernite occurs in the conglomerate exposed in a bulldozer trench at the extreme east margin of the ore body as outlined by drilling. The rock in this trench is considerably below ore grade. Metatorbernite also occurs locally in a few of the beds of carbonaceous shale, most of which are slightly radioactive in the mine area. Except for these sparse crystals of metatorbernite, no uranium minerals have been identified from the carbonaceous shale beds in the upper part of the section in the mine area.

No veins nor evidence of hydrothermal alteration was observed in the rocks in the mine area. The intimate association of uranium and carbonaceous material and the lack of uranium in the enclosing. rocks suggests the carbonaceous material caused the uranium to be precipitated from solutions passing through the rock. Since there is no evidence of hydrothermal activity - veins, alteration, or unusual concentrations of sulfide minerals-the solution that transported the uranium was probably ground water.

Uranium deposits occur in Montana in a somewhat similar geologic setting (Becraft, 1958). The uranium in the Montana deposits was clearly leached from glassy tuffs during bentonitization of the tuffs and deposited in adjacent interbedded carbonaceous shale by ground water. At the Northwest Uranium mine such a source for the uranium in the ground water is not as clearly demonstrable. In the Montana deposits the tuffs were made up of 50 to 90 percent pumice, which apparently contained most of the uranium. The unaltered tuffs assayed 0.009 percent uranium. At the Northwest Uranium mine the tuffaceous sandstone consists largely of unaltered mineral fragments and contains no unusual radioactivity. Also the greatest concentration of uranium at the Northwest Uranium mine is near the base of a conglomerate that is about 100 feet thick and not in the carbonaceous shale that is interbedded with overlying tuffaceous sandstones. This, of course, does not eliminate the tuffs-or similar tuffs containing more glass that may have been removed by erosionas the source of the uranium, but such a source cannot be satisfactorily demonstrated locally with present data. Among other possible sources of the uranium in the ground water are: (1) uranium released during weathering of the porphyritic quartz monzonite (2) uranium from deposits along contacts of the granite and earlier metamorphic 
rocks similar to the Midnite deposit and (3) uranium from veins in the porphyritic quartz monzonite or Gerome andesite, although no such veins are known. Serious objections are apparent to each of these, and thus the source of the uranium in the ground water is unknown.

The age of the deposit is also unknown, except that it is younger than the Gerome formation.

Middle Tertiary pyroclastic and sedimentary rocks similar to the Gerome at the Northwest Uranium mine are common in several places in northeastern Washington and should be prospected carefully for similar uranium deposits. Any slight radioactivity anomaly should be examined thoroughly because at the Northwest Uranium mine slight radioactivity observed at the surface led to the discovery of the large, low-grade ore body which did not crop out.

\section{LOWLEY LFASE}

The Lowley Lease (pl. 1, No. 4) is in SW1/4 sec. 13, T. 27 N., R. 37 E., along the contact between Paleozoic(?) impure quartzite and granodiorite of the Loon Lake granite (pl. 5). The geology in the vicinity of the lease was mapped by Becraft in 1957 on a topographic base map made by geologists of the U.S. Atomic Energy Commision. The lease has been explored by several shallow diamond-drill holes and by extensive bulldozing along the contact. In 1957 an inclined shaft was sunk 60 feet on the most radioactive area along the contact and two drifts totaling 400 feet in length were driven from the shaft at a depth of 50 feet to the northwest and southeast along the contact. Both the quartzite and granodiorite along the contact are intensely sheared over a zone that ranges from a few feet to more than 20 feet in width. The radioactive rock is confined to local areas along this sheared zone over a distance of several hundred feet.

Uranium minerals reported from the sheared zone by geologists of the U.S. Atomic Energy Commission are meta-autunite, uranophane, coffinite(?), and uraninite (Donald L. Hetland, oral communication, 1959).

About 285 tons of uranium-bearing rock were shipped from the lease in 1956. In 1958 diamond drilling as part of Defense Minerals Exploration Administration contract IDM-E1203 was in progress to determine whether a uranium ore body existed at depth along the contact.

\section{BIG SMOKE MINE}

The Big Smoke mine (pl. 1, No. 3) is in sec. 11, T. 27 N., R. 37 E., in pyroclastic and sedimentary rocks of the Gerome. The radioactive rock is exposed in a bulldozer cut along a faulted contact between the Gerome and granodiorite of the Loon Lake granite. The mine area 
has been explored by several shallow, percussion-drill holes and extensive bulldozing.

The uranium occurs in and adjacent to carbonaceous shale that has been intensely sheared along the fault. Only minor amounts of uranium have been discovered, and the only uranium mineral identified from the deposit is metatorbernite, which occurs as sparse, small crystals in sandstone near the carbonaceous shale.

\section{DEeR MOUNTAIN PRospect}

Secondary uranium minerals are present in the rock on a small nose on the west side of Deer Mountain (pl. 1, No. 5) in sec. 21, T. 29 N., R. $38 \mathrm{E}$., where a bulldozer trench exposes the contact between schist of the Togo formation and porphyritic quartz monzonite of the Loon Lake granite. The schist at the contact strikes N. $40^{\circ}$ E., and dips $63^{\circ} \mathrm{W}$. The contact is marked by a zone of intensely sheared rock about 5 feet thick that strikes about N: $5^{\circ} \mathrm{W}$., and dips $45^{\circ} \mathrm{W}$.

Small, sparse flakes of secondary uranium minerals, probably metaautunite and uranophane, occur in a few places in the sheared rock along the intrusive contact. Shearing is too intense to permit certain identification of the rock containing the uranium minerals, but most of it is probably Togo formation. No ore-grade material was seen at the deposit.

\section{COPPER: O-LO-IIM MINE}

The O-Lo-Lim mine (pl. 1, No. 6) is near the center of sec. 9, T. 28 N., R. 37 E., about a mile north of Sand Creek. The property was mined between 1917 and 1920. Production was valued at about $\$ 18,000$.

The deposit is a quartz vein 2 feet to 6 feet thick, in argillite of the Togo formation. The vein strikes N. $20^{\circ} \mathrm{E}$. and dips about $70^{\circ} \mathrm{E}$. It was explored by a vertical shaft 200 feet deep, and another 100 feet deep with 15-foot and 35-foot drifts at the bottom. All workings are now inaccessible.

Ore minerals are chalcopyrite, pyrite, bornite, malachite, and tenorite, in a gangue of quartz and tremolite.

\section{MOLYBDENUM: SPOKANE MOLYBDENUM MINE}

The Spokane Moly bdenum mine (pl. 1, No. 7) is on the north side of Pitney Butte in sec. 32, T. 28 N., R. 37 E. The country rock is fine-grained quartz monzonite of the Loon Lake granite, which is cut by a dike of Gerome (fig. 9). Veins are of two types: milky quartz, and gray, massive quartz segregations that are a part of small muscovite-rich pegmatites. Some of the gray quartz contains traces of fluorite. 

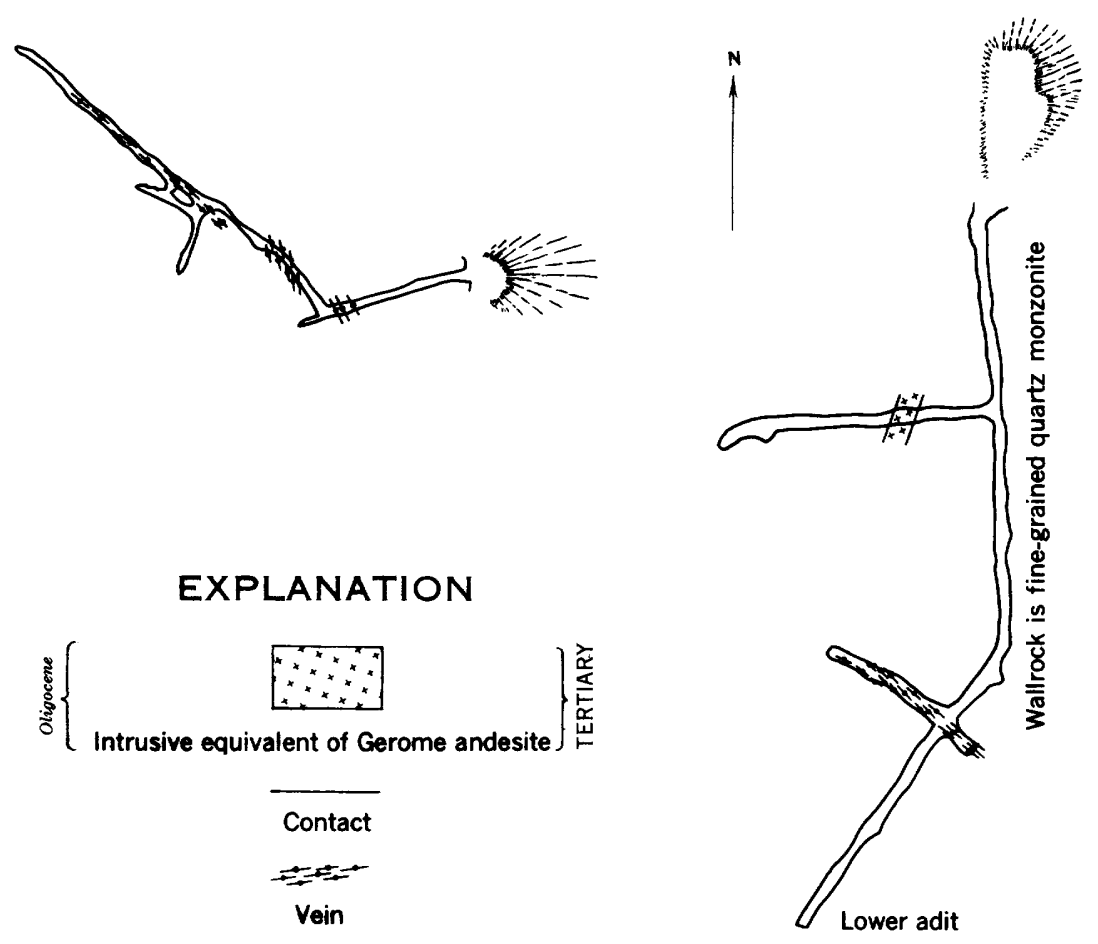

\section{EXPLANATION}
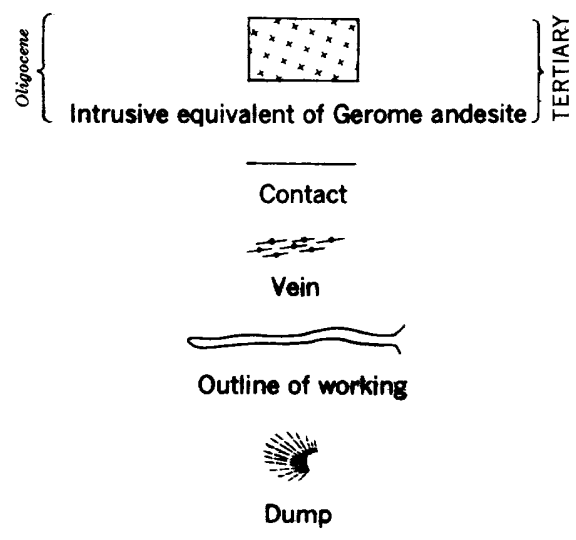

Geology by P. L. Weis and F. C. Armstrong, 1953

100

100 200 FEET

FigUre 9.-Geologic map of the underground workings, Spokane molybdenum mine.

The principal vein, which is of milky quartz, is as much as 8 feet thick. It strikes about N. $40^{\circ} \mathrm{W}$. and is nearly vertical. The vein consists of molybdenite, pyrite, chalcopyrite, and sphalerite in a quartz gangue. The molybdenite occurs as sparse flakes and flattened masses as much as 3 inches wide, scattered through the quartz.

A small stringer of pitchblende was identified cutting the milky quartz vein in the lower tunnel (J. S. Vhay, written communication, 1950), but no additional occurrences of radioactive material are known at the property. Underground workings consist of two adits and several crosscuts (fig. 9). F. C. Armstrong, U.S. Geological . Survey, and Weis mapped the underground workings that existed in 
1953, and in 1957 Weis mapped an extension of the lower adit that had been driven in 1956 .

No production is known from the mine.

\section{LEAD-ZINC}

\section{ORAZADA MINE}

The Orazada mine (pl. 1, No. 8) in sec. 27 , T. 29 N., R. 37 E., is in a narrow brecciated zone in Edna dolomite. The zone is characterized by heavy gossan at the surface. Development consisted of a 2,400-foot adit, another adit of unknown length, and several trenches. Underground workings are now inaccessible.

The mineralized rock consists of jamesonite, pyrite, arsenopyrite, galena, and sphalerite, in a gangue of quartz, calcite, and barite. A test shipment was made in 1940 , but no production is reported.

\section{VALLEX VIEW MINE}

The Valley View mine (pl..1, No. 9) on the north side of Pitney Butte in sec. 32 , T. 28 N., R. 37 E., is on a quartz vein containing scattered pods of sphalerite, galena, and pyrite. The vein cuts fine-grained quartz monzonite of the Loon Lake granite. Development consists of two adits, a drift, and a shaft. The lower adit is 100 feet long, and the upper is 80 feet long and has a 60 -foot drift. A 50-foot shaft was sunk at the portal of the upper adit. No production from the deposit is known.

\section{FOURESS (4-8) MINE}

The Fouress (4-S) mine (pl. 1, No. 10) is on the northwest side of Pitney Butte in sec. 32, T. 28 N., R. 37 E. The exploration work, which consists of one 500 -foot adit and three 100 -foot shafts, has been done on a quartz vein 1 to 4 feet thick that cuts fine-grained quartz monzonite of the Loon Lake granite. The vein is traceable underground for about 100 feet, and for about 40 feet of this length it contains scattered sphalerite, pyrargyrite, and native silver. The ore reportedly assayed 7 percent zinc, 0.87 ounce silver, and 0.04 ounce gold. No production is reported from the deposit.

\section{MATHERLY PROSPECT}

The Matherly prospect (pl. 1 No. 11) in secs. 4 and 9, T. 27 N., R. $37 \mathrm{E}$., is in equigranular quartz monzonite of the Loon Lake granite. The prospect explores a quartz vein $1 \frac{1}{2}$ to $3 \frac{1}{2}$ feet thick that is exposed in an adit for a distance of about 60 feet. The vein contains pyrite, galena, and arsenopyrite in quartz gangue. Development consists of a 90 -foot adit, and a winze of unknown depth that is now flooded (fig. 10). No production is known from this deposit. 


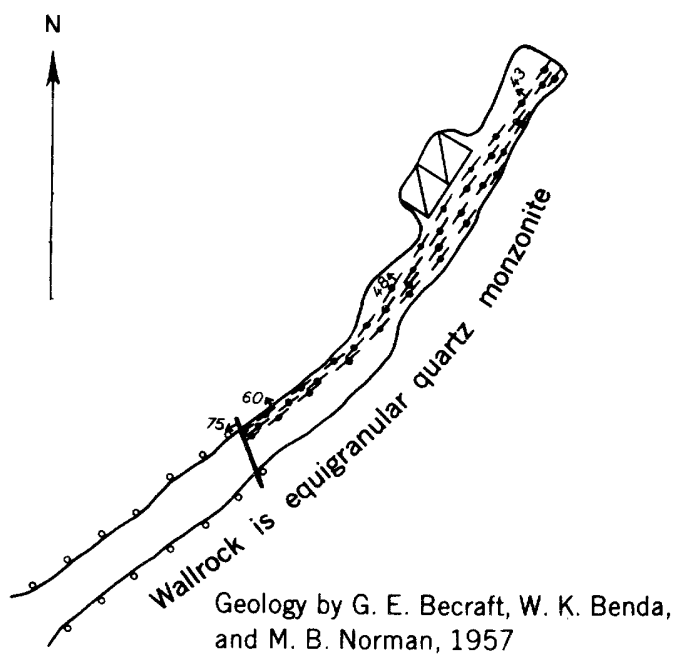

\section{EXPLANATION}
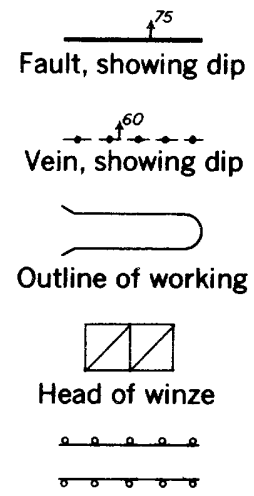

Timbering along drift

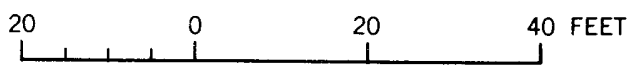

F1GURE 10.-Geologic map of the underground workings, Matherly prospect.

\section{MANGANESE: TURTLE LAKE PROSPECT}

An area about 300 feet wide and 250 feet long in the SW1/4 sec. 16, T. 28 N., R. 38 (pl. 1 No. 12), is underlain by disaggregated quartz monzonite that has been cemented by manganese oxides. Bulldozer trenches in the cemented material show it to be from 1 to 3 feet thick. No attempt has been made to mine the material. Grade is estimated to be 15 to 20 percent manganese oxide.

\section{TUNGSTEN: GERMANIA CONSOLIDATED MINE}

The Germania Consolidated mine (pl. 1, No. 13) is in secs. 23 and 26, T. 29 N., R. 37 E., near the head of Owl Creek, a south-flowing tributary of Sand Creek, near the north edge of the Spokane Indian Reservation. The deposit consists of three parallel northeast-striking, steeply dipping, quartz veins that cut equigranular quartz monzonite of the Loon Lake granite. The principal ore mineral is ferberite, but the veins also contain minor amounts of molybdenite, scheelite, pyrite, magnetite, chalcopyrite, and bismuthinite. The maximum thickness of the veins is about 15 inches. The maximum strike length of the veins is reported to be about 1,300 feet (Huntting, 1956, p. 348). Workings on three levels (pl.6) include more than 3,000 feet of opencuts, stopes, shafts, adits and crosscuts. A map of the underground workings was compiled by W. P. Puffett in 1952, in connection with a Defense Minerals Exploration Administration examination (Docket 
No. DMEA 2447). A 25-ton mill was erected at the property. Total production of tungsten through 1955 is valued at about $\$ 134,000$.

\section{SIHICA DEPOSIT}

A pegmatite in the $\mathrm{SW}^{1 / 4}$ sec. 6 , T. 27 N., R. $37 \mathrm{E}$ (pl. 1, No. 14), has a quartz core of sufficient size and purity to constitute a potential source of silica for metallurgical uses. The roughly circular quartz pod that forms the interior of the pegmatite is at least 250 feet in maximum width. The quartz is surrounded by a layer of randomly oriented, massive muscovite. Country rock is equigranular quartz monzonite of the Loon Lake granite. No attempt has been made to mine the deposit.

\section{BARITE PROSPECT}

A pyrite-bearing barite vein (pl. 1, No. 15) about 4 feet thick is in quartzite of the Edna in sec. 22 , T. 29 N., R. 37 E., about half a mile north of the Orazada mine. The vein is along a fault that strikes about $\mathrm{N} .25^{\circ} \mathrm{W}$. and appears to dip steeply to the north. The barite, which makes up most of the vein material, is white, coarse, and massive. The deposit has not been worked.

\section{COAL PROSPECT}

A seam of carbonaceous material that contains small stringers of coal is present in sec. 8 , T. 28 N., R. 37 E., near Ferguson Creek about half a mile above its mouth (pl. 1, No. 16). The coaly material is in a layer of sedimentary rock between two flows of Gerome andesite. A short inclined shaft was sunk on the seam, but no production is known.

\section{LITERATURE CITED}

Bancrof $t$, Howland, 1914, The ore deposits of northeastern Washington: U.S. Geol. Survey Bull. 550, 215 p.

Barrington, Jonathan, and Kerr, P. F., 1961, Uranium mineralization at the Midnite mine, Spokane, Washington: Econ. Geology, v. 56, no. 2, p. 241-258.

Becraft, G. E., 1958, Uranium in carbonaceous rocks in the Townsend and Helena Valleys, Montana: U.S. Geol. Survey Bull. 1046-G, p. 149-164.

Bennett, W. A. G., 1941, Preliminary report on magnesite deposits of Stevens County, Washington: Washington Div. Geology Rept. Inv. 5, 25 p.

- 1944, Dolomite resources in Washington: Washington Div. Geology Rept. Inv. 13, 35 p.-Supp. Pt. 1, Preliminary report on Okanogan, Lincoln and Stevens Counties, 15 p., 1945.

Bethune, G. A., 1891, Mines and minerals of Washington in Annual report of First State Geologist, 1890: Washington Geol. Survey, $122 \mathrm{p}$.

Bretz, J H., 1923, Glacial drainage on the Columbia Plateau: Geol. Soc. America Bull., v. 34, no. 3, p. 573-608.

Bretz, J H., Smith, H. T. U., and Neff, G. E., 1956 Channeled scabland of Washington-New data and interpretations: Geol. Soc. America Bull., v. 67, no. 8 , p. $957-1050$.

Bryan, Kirk, 1927, The "Palouse Soil" problem: U.S. Geol. Survey Bull. 790-B, p. 21-45. 
Calkins, F. C., 1905, Geology and water resources of a portion of east-central Washington: U.S. Geol. Survey Water-Supply Paper 118, $96 \mathrm{p}$.

Campbell, Ian, and Loofbourow, J. S., Jr., 1957, Preliminary geologic map and sections of the magnesite belt, Stevens County, Washington: U.S. Geol. Survey Mineral Inv. Field Studies Map MF-117.

Culver, H. E., 1937, Extensions of the Ringold formation: Northwest Sci., v. 11, p. $57-60$.

Culver, H. E., and Broughton, W. A., 1945, Tungsten resources of Washington: Washington Div. Geology Bull. 34, 89 p.

Flint, R. F., 1936, Stratified drift and deglaciation of eastern Washington: Geol. Soc. American Bull., v. 47, no. 12, p. 1848-1884.

1937, Pleistocene drift border in eastern Washington: Geol. Soc. America Bull., v. 48, no. 2, p. 203-232.

Floyd, P. H., and Stickney, W. A., 1954, Beneficiation of ferberite-scheelite ore from the Germania Consolidated Mines, Inc., Stevens County, Washington: U.S. Bur. Mines Rept. Inv. 5039, 6 p.

Fyfe, W. S., Turner, F. J., and Verhoogen, Jean, 1958, Metamorphic reactions and metamorph c facies: Geol. Soc. America Mem. 73, $259 \mathrm{p}$.

Hargrove, Don, 1958, Dawn's new uranium mill achieves high extraction: Eng. Mining Jour., v. 159, no. 3, p. 90-97, 118.

Huntting, M. T., 1956, Metallic minerals-Pt 2 of Inventory of Washington minerals: Washington Div. Mines and Geology Bull. 37, v. 1, 428 p.

Jones, F. O., Embody, D. R., and Peterson, W. L., 1961, Landslides along the Columbia River valley, northeastern Washington: U.S. Geol. Survey Prof. Paper 367, $98 \mathrm{p}$.

Kirkham, V. R. D., and Johnson, M. M., 1929, The Latah formation in Idaho: Jour. Geology, v. 37, no. 5, p. 483-504.

Krynine, P. D., 1937, Age of till on "Palouse soil" from Washington: Am. Jour. Sci., v. 33, p. 205-216.

Landes, Henry, and others, 1902, The metalliferous resources of Washington, except iron in Annual report for 1901: Washington Geol. Survey, v. 1, pt. 2, p. 39-119.

Little, H. W., 1950, Salmo map area, British Columbia: Canada Geol. Survey Paper 50-19, 43 p.

Okulitch, Vladimir J., 1950, A Lower Cambrian fossil locality near Addy, Washington: Jour. Paleontology, v. 25, no. 3, p. 405-407.

Pardee, J. T., and Bryan, Kirk, 1926, Geology of the Latah formation in relation to the lavas of the Columbia Plateau near Spokane, Washington: U.S. Geol. Survey Prof. Paper 140-A, p. 1-16.

Park, C. F., Jr., and Cannon, R. S., Jr., 1943, Geology and ure deposits of the Metaline quadrangle, Washington: U.S. Geol. Survey Prof. Paper 202, 81 p.

Patty, E. H., 1921, The metal mines of Washington: Washington Geol. Survey Bull. 23, 366 p.

Rankama, Kalervo and Sahama, Th. G., 1950 Geochemistyr: Univ. Chicago Press, $912 \mathrm{p}$.

Reesor, J. E., in Gill, J. E., 1957, The Proterozoic of Canada: Canada Royal Soc. Pub. 2, Toronto Univ. Press, p. 163-165.

Rice, H. M. A., 1941, Nelson map area, east half, British Columbia: Canada Geol. Survey Mem. 228, 86 p. 
Russell, I. C., 1893, A geological reconnaissance of central Washington: U.S. Geol. Survey Bull. 108, 108 p.

1897, Principal features of the geology of southeastern Washington [abs.]: Am. Jour. Sci., v. 4, no. 3, p. 246-248.

1901, Geology and water resources of Nez Perce County, Idaho, Pt 1: U.S. Geol. Survey Water-Supply Paper 53, 85 p.

Sheldon, R. F., 1959, Midnite mine geology and development: Mining Engineer v. 11 , no. 5 , p. 531-534.

Smith, G. O., 1901, Geology and water resources of a portion of Yakima County, Washington: U.S. Geol. Survey Water-Supply Paper 55, 68 p.

Treasher, R. C., 1925, Origin of the loess of the Palouse region, Washington: Science, n. s., v. 61, p. 469.

Valentine, G. M., 1949, Nonmetallic minerals-Pt. 1, of Inventory of Washington minerals: Washington Div. Mines and Geology Bull. 37, 113 p.

Walker, J. F., 1934, Geology and mineral deposits of the Salmo map area, British Columbia: Canada Geol. Survey Mem. 172, pub. 2345, $102 \mathrm{p}$.

Waters, A. C., 1961, Stratigraphic and lithologic variations in the Columbia River basalt: Am. Jour. Sci., v. 259, no. 8, p. 583-611.

Weaver, C. E., 1920, The mineral resources of Stevens County: Washington Geol. Survey Bull. 20, 350 p. 
